\title{
إدارة الشباب لوقت الفراغ و علاقته بالرضا عن الحياة
}

\author{
اعلداد \\ |. م.د نحلاء سيد حسين \\ أستاذ مساعد بقسم إدارة مؤسسات الأسرة و الطفولة \\ كلية الاقتصاد المنزلي - جامعة حلوان
}

مجلة بحوث التربية النوعية ـ جامعة المنصورة

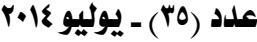




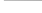

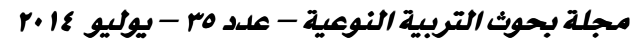

\section{إدارة الشباب لوقت الفراغ و علاقته بالرضا عن الحياة}

إعداد

*

:صغال|

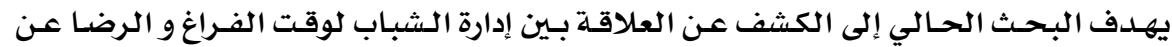

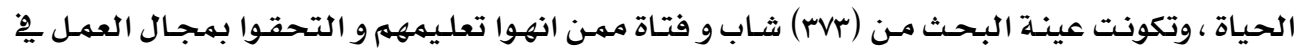

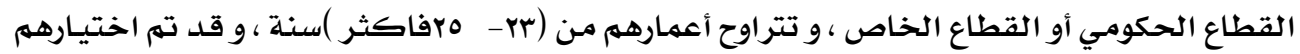

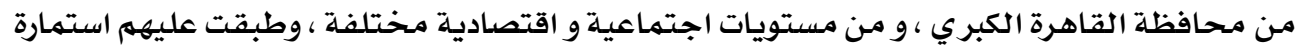

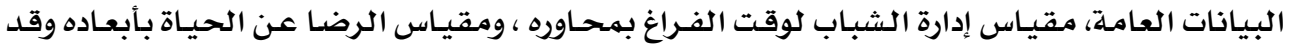

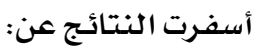

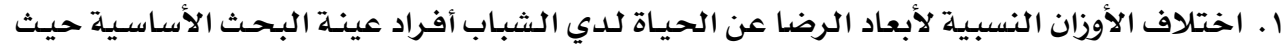

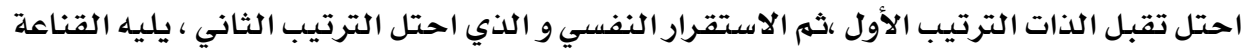

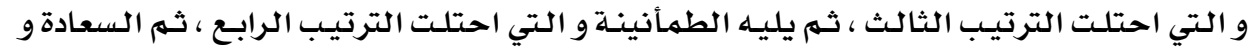

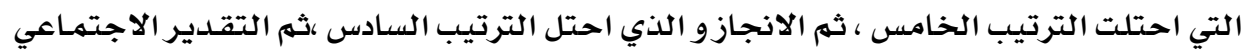

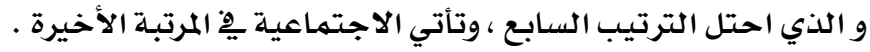

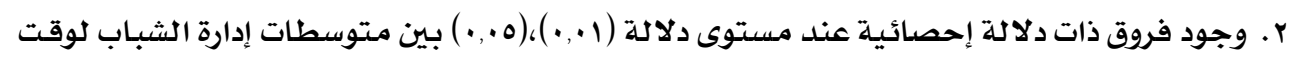

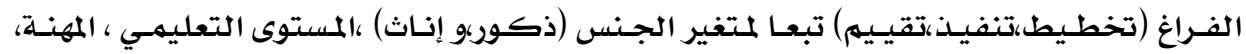

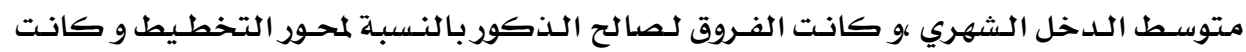

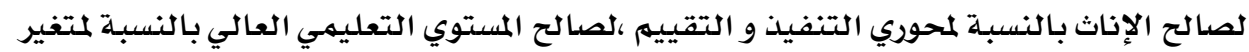

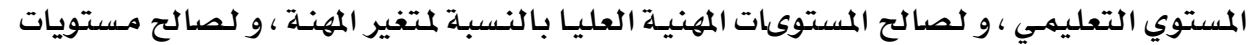

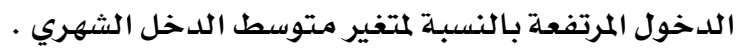

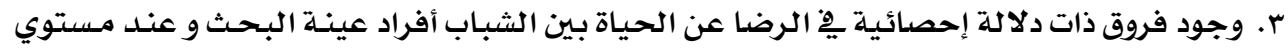

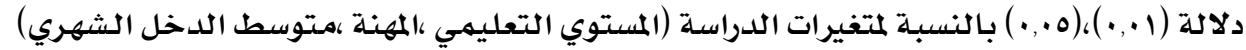

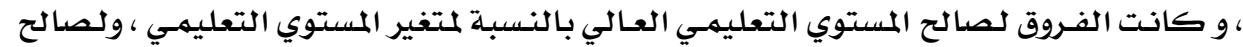

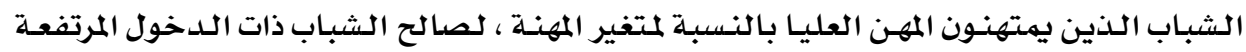

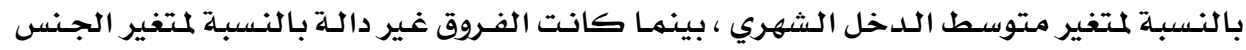

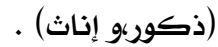

" أستاذ مساعد بقسم إدارة مؤسسات الأسرة و الطفولة - كلية الاقتصاد المنزلي - جامعة حلوان 


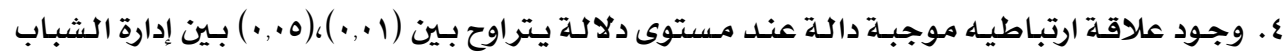

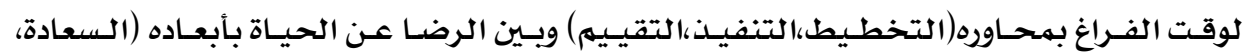

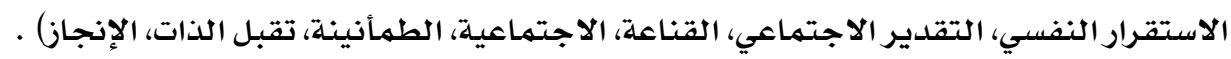
ه. وجود علاقة ارتباطية موجبـة بين إدارة الشباب لوقت الفراغ بمحاوره (التخطيط،التنفيذ،التقييهم)

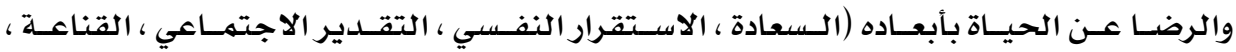

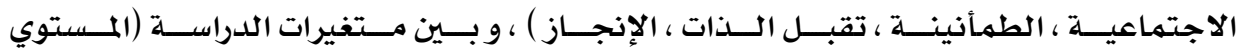

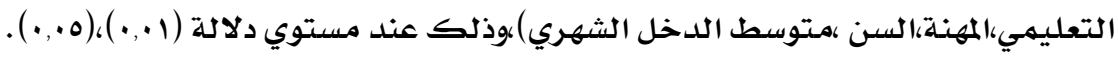

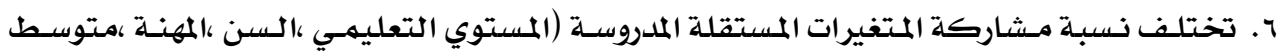

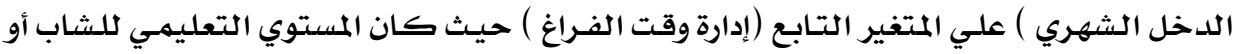

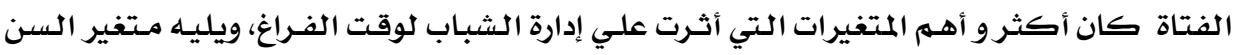

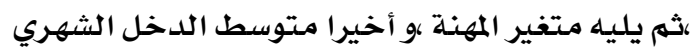

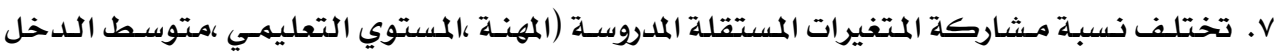

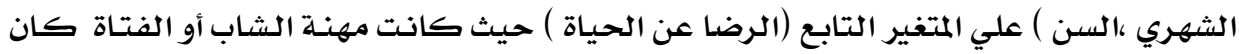

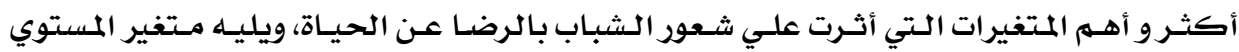

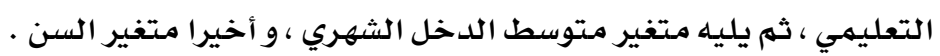

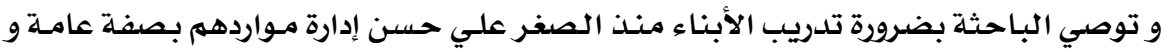
مورد وقت الفراغ بصفة خاصـة بما يعود عليهمه و علي المجتمع بالفائدة .

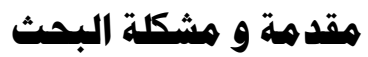

يعد الوقت مورد هام ِِّ حياة كل فرد فهو من أعظم الموارد التي يمتلكها الإنسان قي الحياة

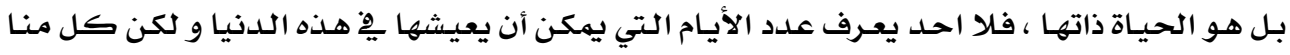

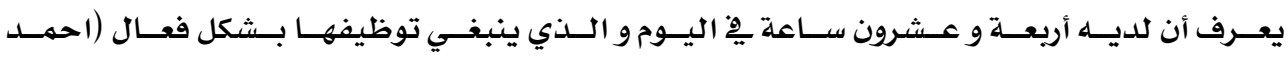

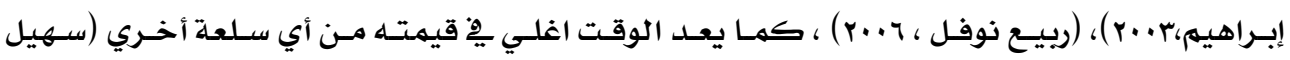

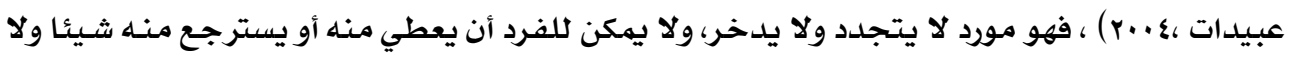

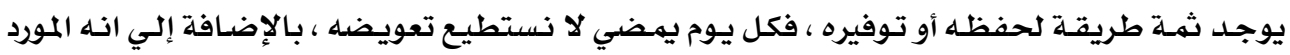

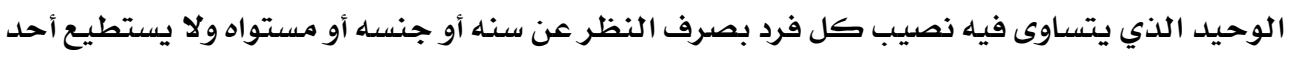

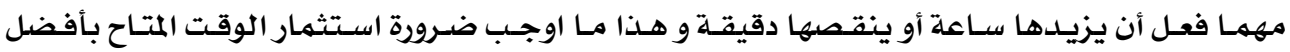

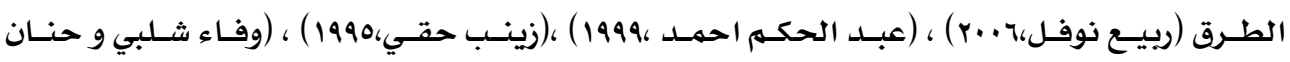

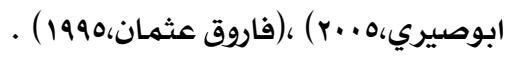

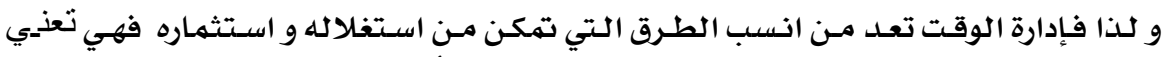

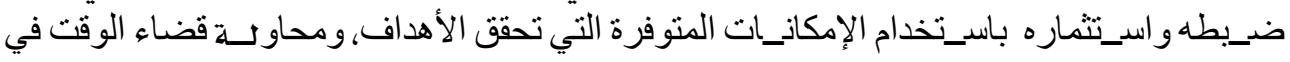

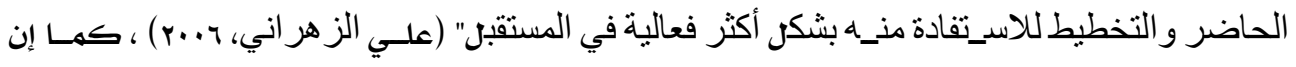




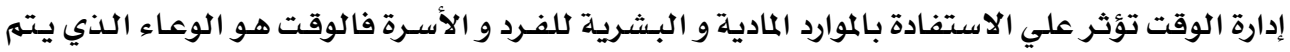

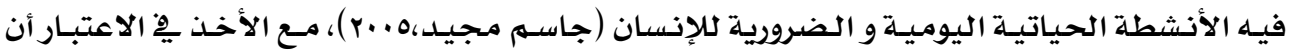

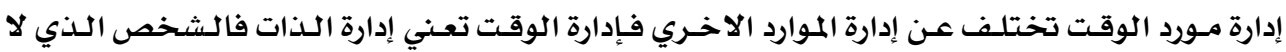

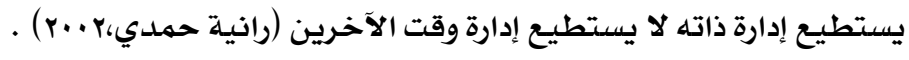

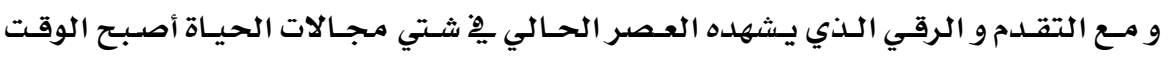

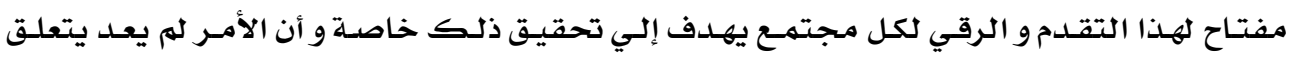

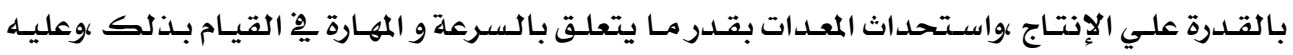

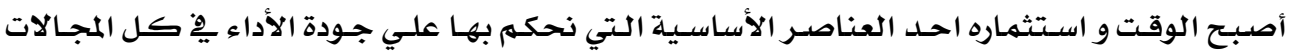

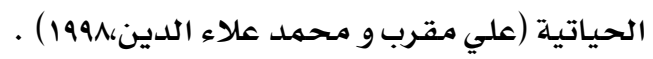

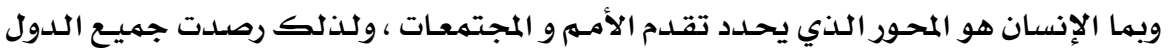

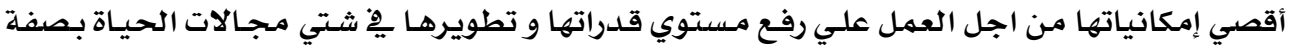

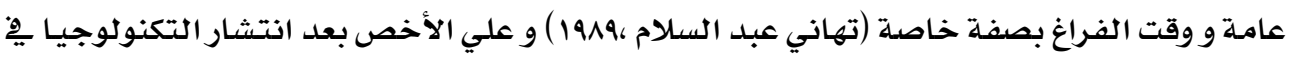

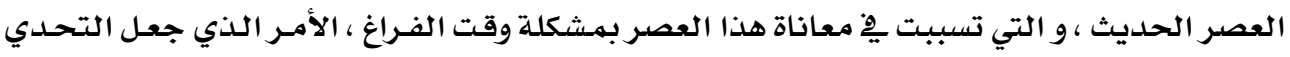

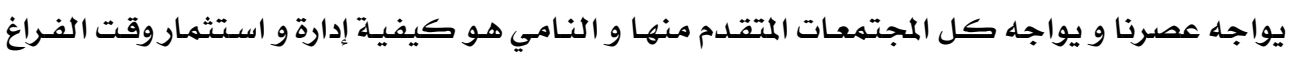

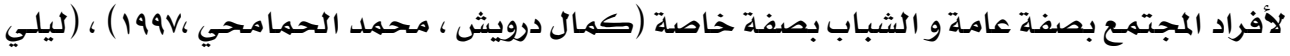

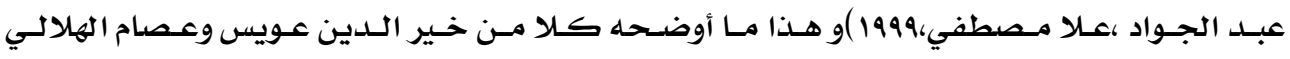

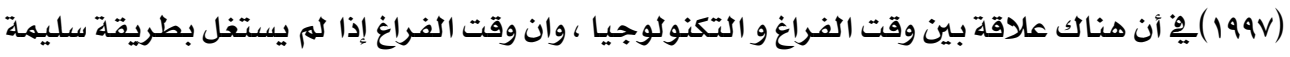

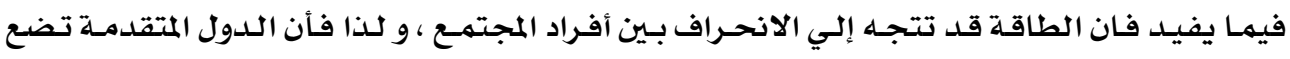

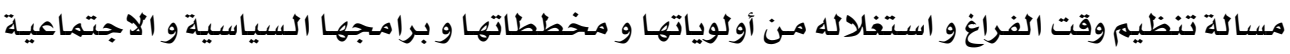

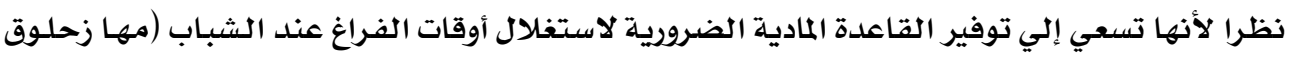

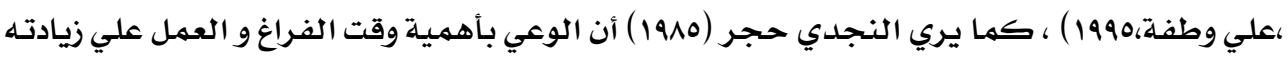

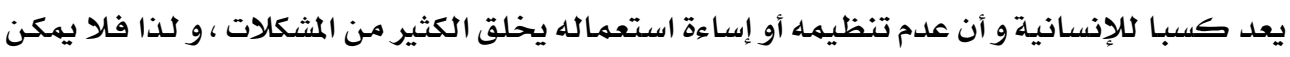

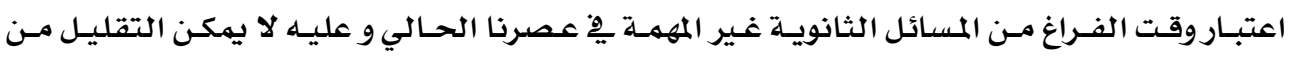

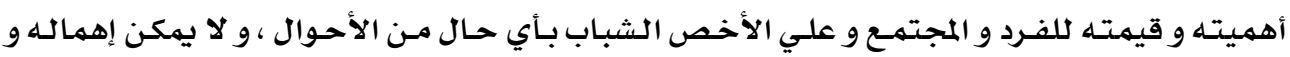

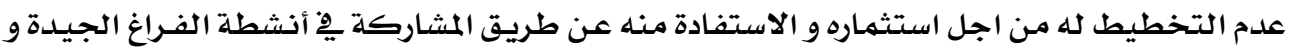

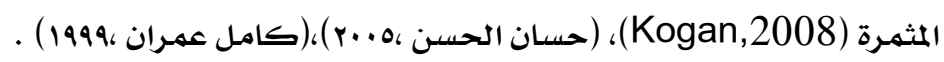

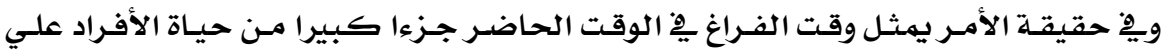

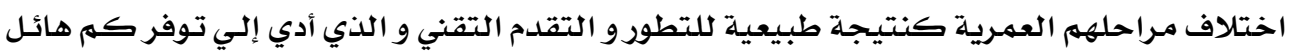

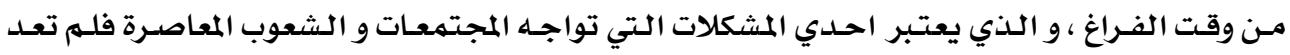

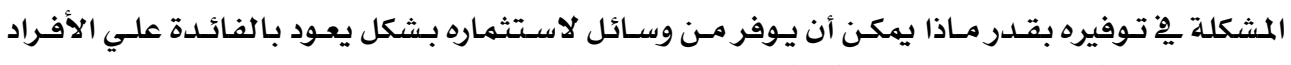

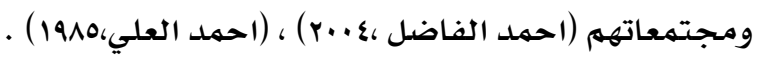




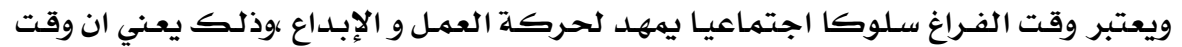

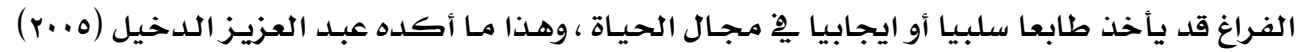

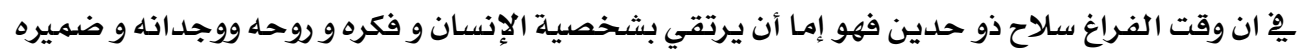

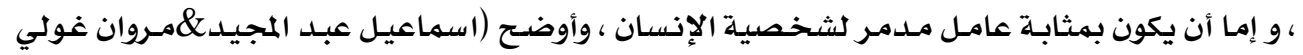

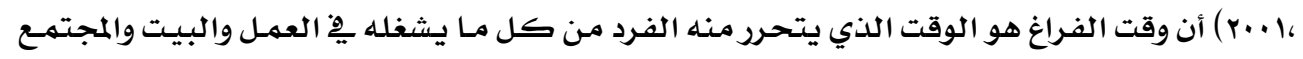

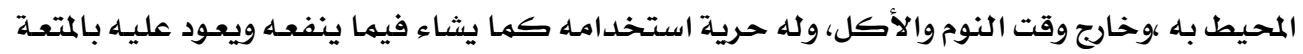

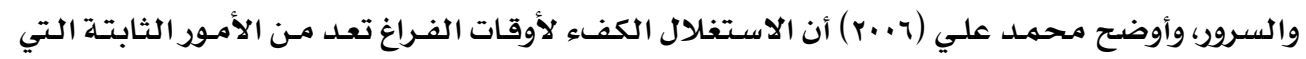

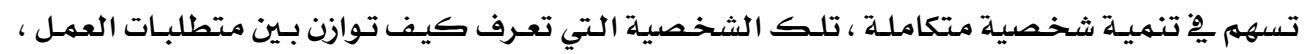

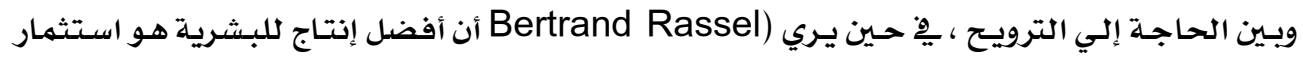

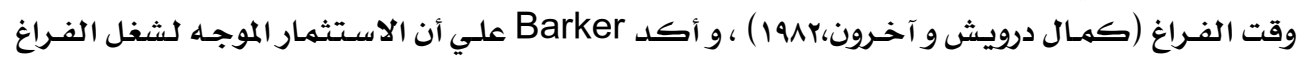

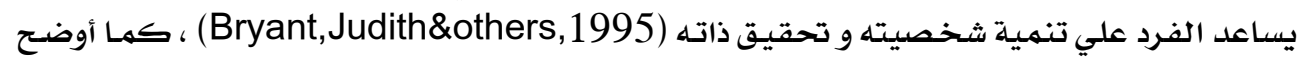

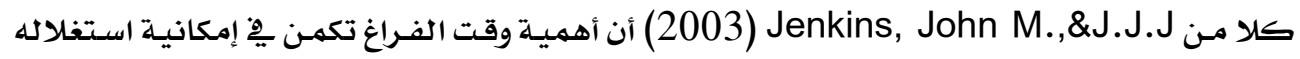

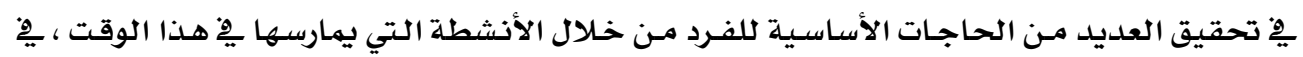

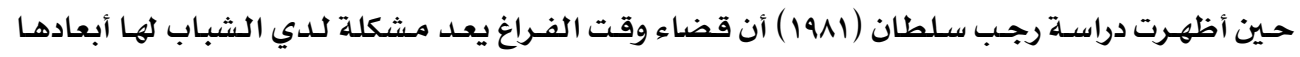

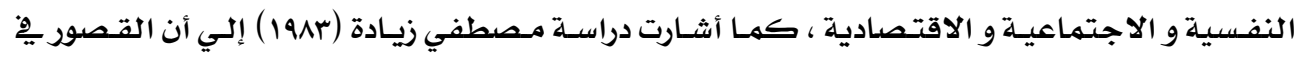

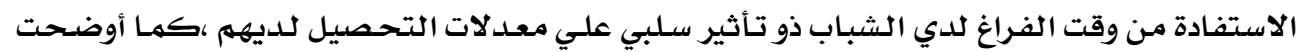

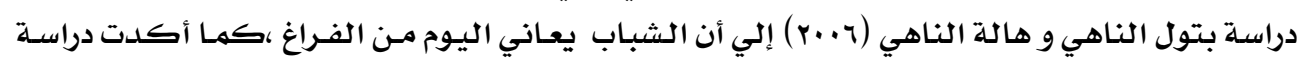

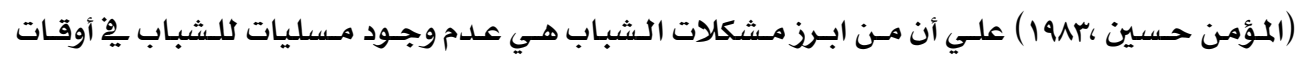
فراغهم ، وكشفت دراسـة Turner\& et al(2005 إلي وجود علاقة ارتباطيه ذات دات دلالة إحصائية بين

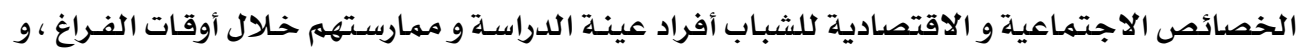

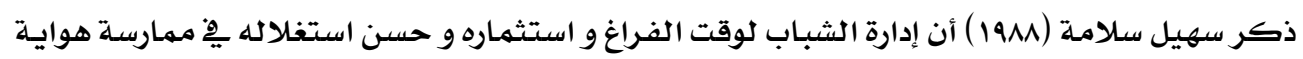

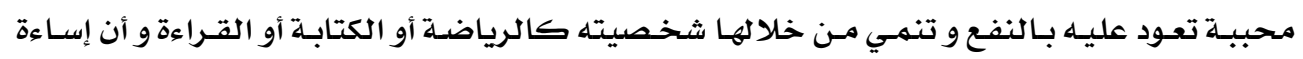

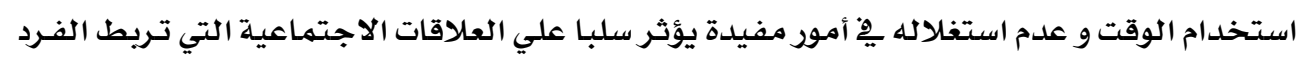

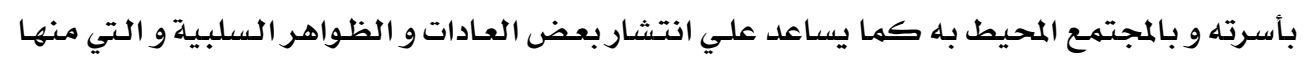

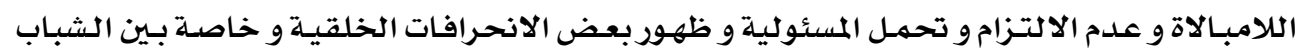

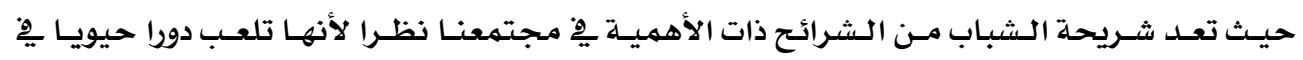

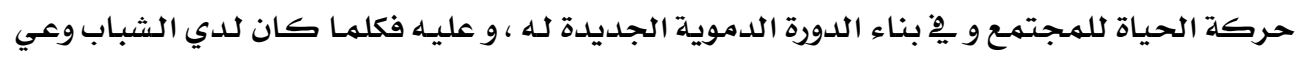

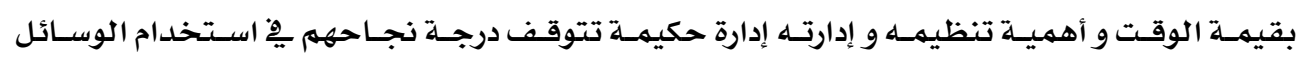

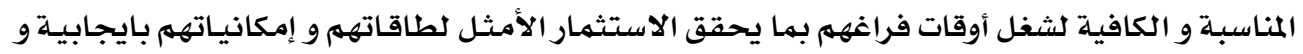

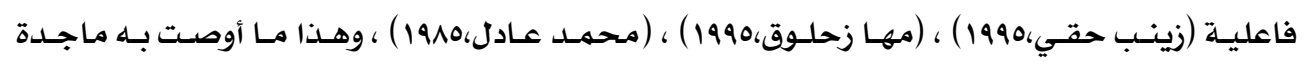

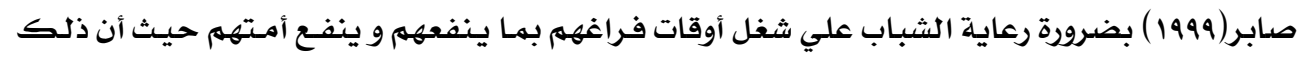
سوف ينعكس عليهم بايجابية ورضا عن الحياة . 
و يعتبر الرضا عن الحياة من المفاهيم النفسية التي حظيت باهتهام كبير ،وذلك لاعتبـار

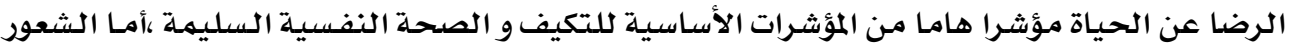

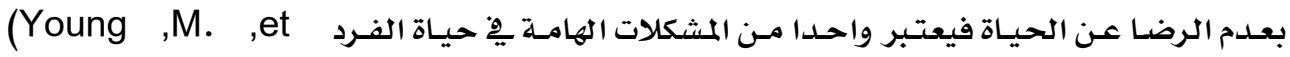

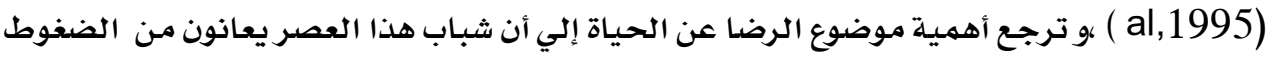

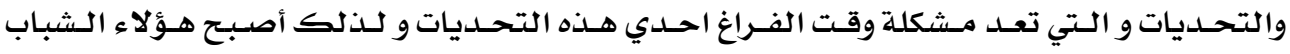

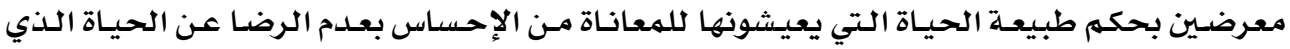

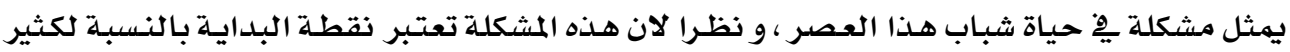

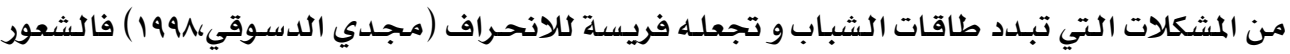

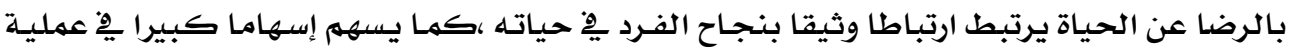

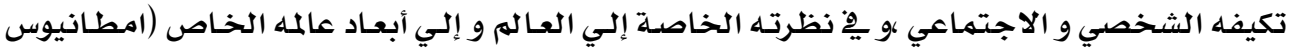

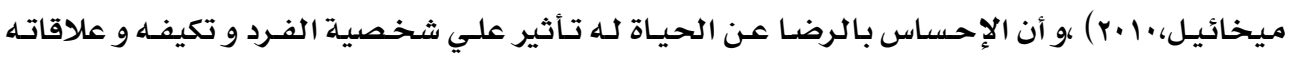

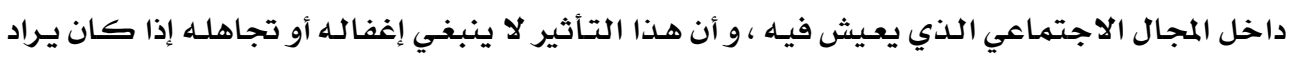

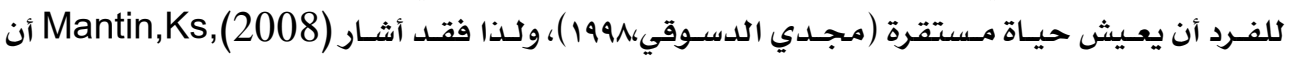

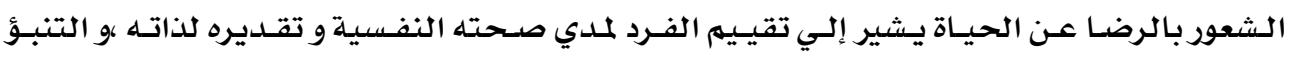

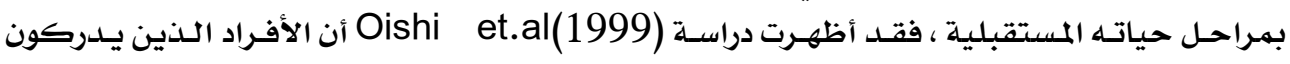

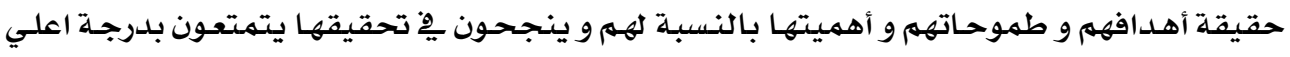

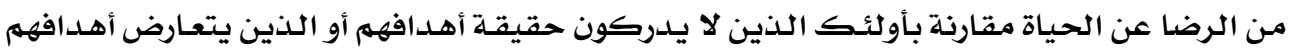

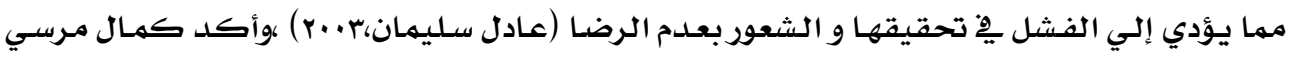
(r...)

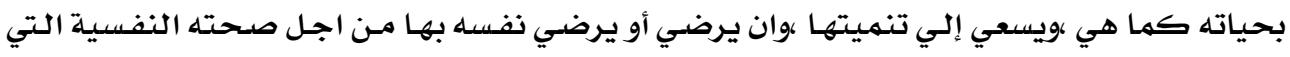

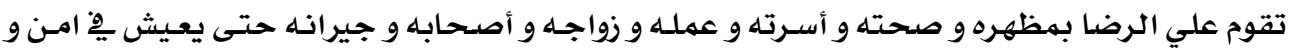

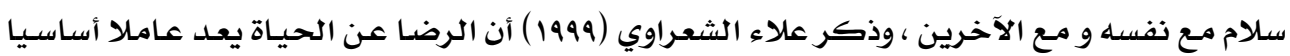

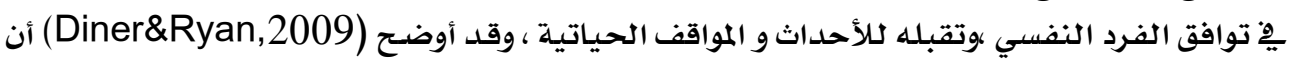

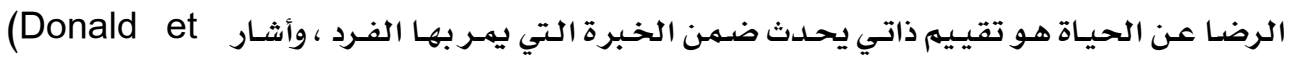
al,2011)

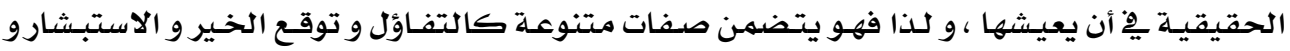

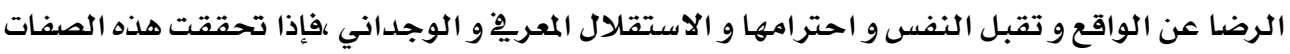

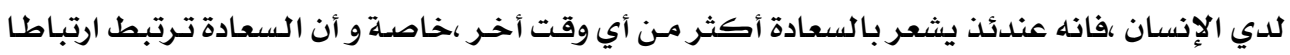

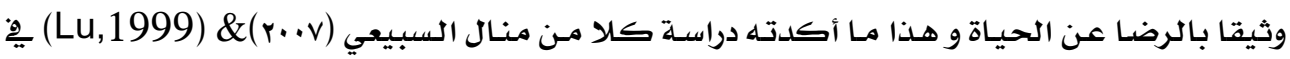

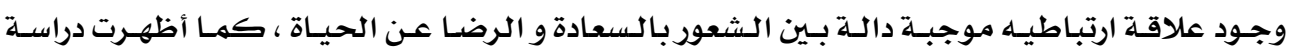
(Heo\&Lee,2010)

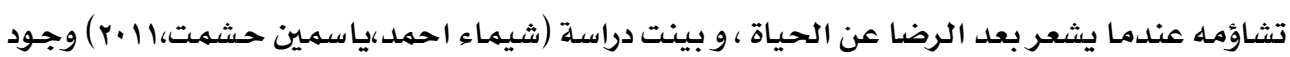


علاقة ارتباطيه موجبة بين مستوي السعادة و هي احدي أبعاد الرضا عن الحياة و بين مستوي الدخل و الرضا عن الحياة بصفة عامـة .

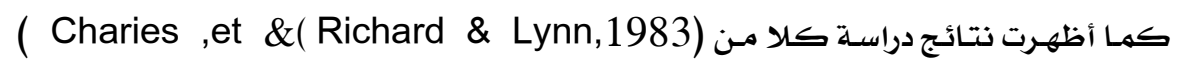

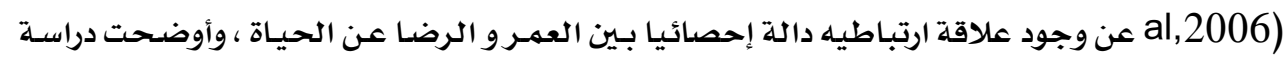
(Donald \& Jeannette,1992)

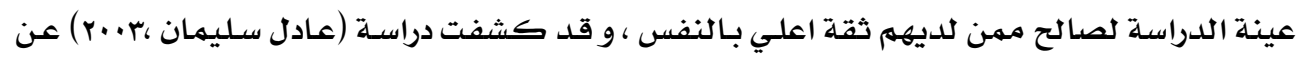

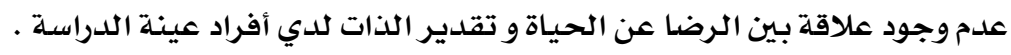

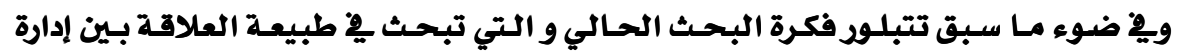

الشباب لوقت الفراغ و بين الرضا عن الحياة من خلال الإجابة علي التساؤلات الآتية :

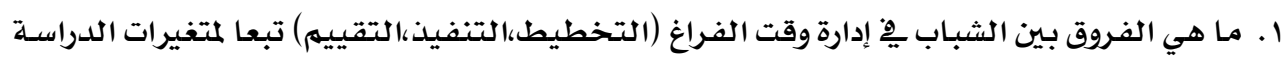

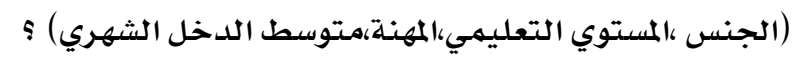

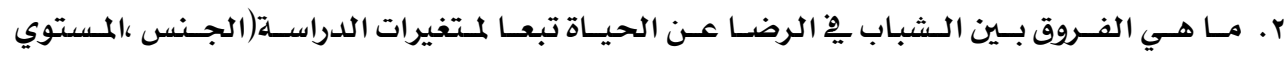

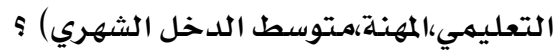

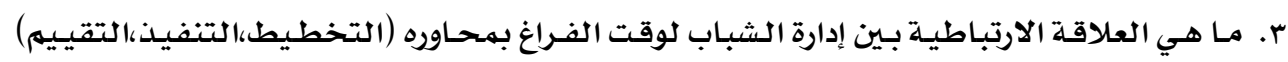

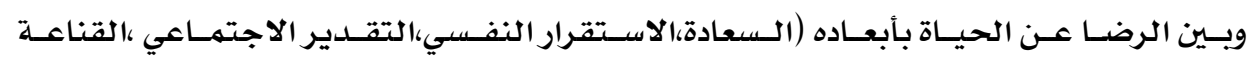

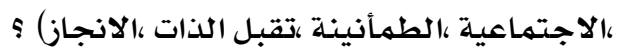

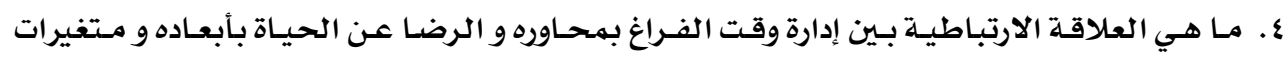

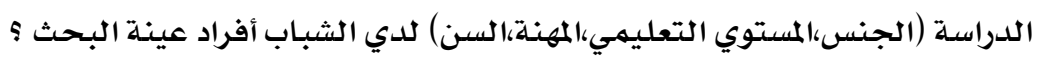

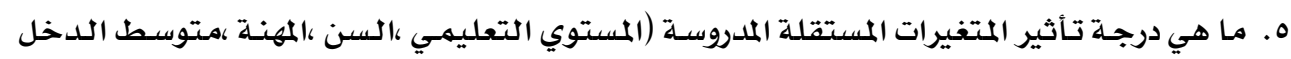

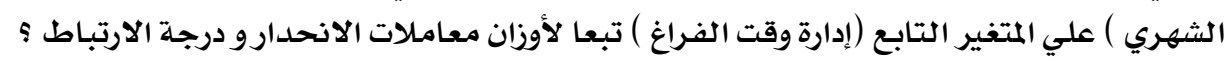

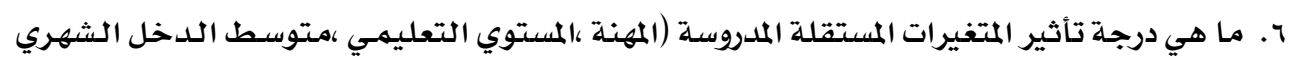

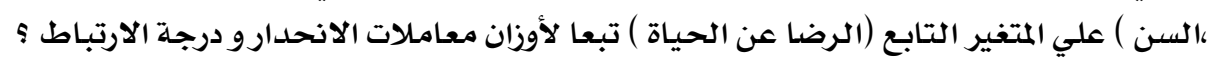

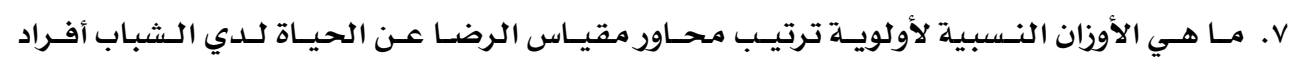
عينة البـحث ؟ مي الاوز

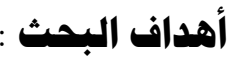

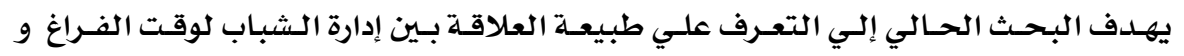
الرضا عن الحياة من خلال الأتي : البحث الهي

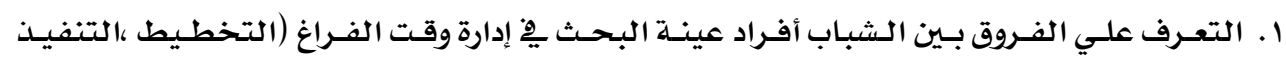

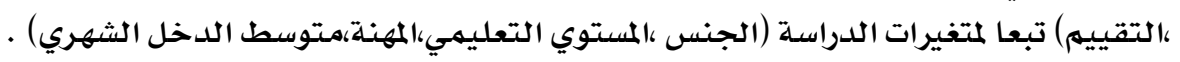


مجلة بحوث التربية النوعية - علد مبr - بوليو

ץ. التعـرف علسي الفـروق بـين الشباب يِّ الرضـا عـن الحيـاة تبعـا لمتغيرات الدراسـة(الجـنس ،المستوي

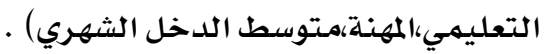

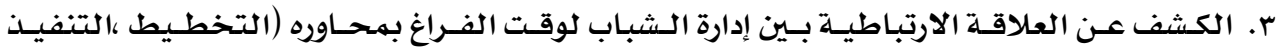

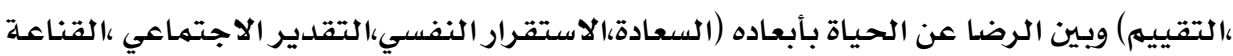

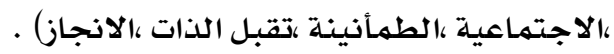

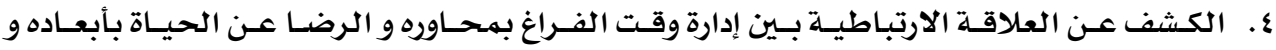

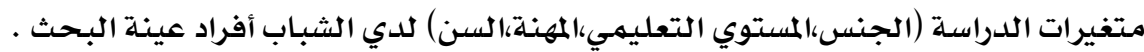
ه. تحديد مدي تأثير المتغيرات المستقلة المدروسـة (المستوي التعليهـي ،السن ،المهنـة ،متوسط الداخل

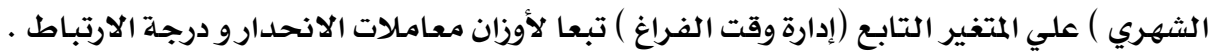

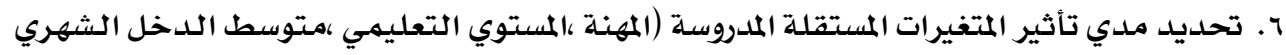

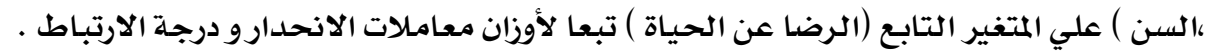
V. التعرف علي الأوزان النسبية لأولويـة ترتيب محساور مقيـاس الرضـا عن الحيـاة لدي الشباب أفراد عينة البحث .

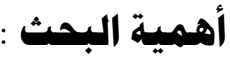

\section{تتمثل أهمية البحث الحالي فيما يلي :}

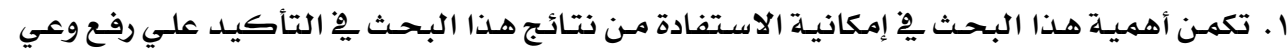

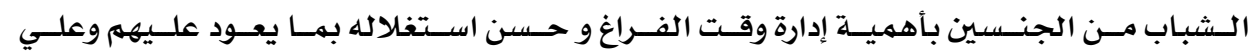

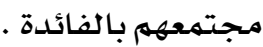

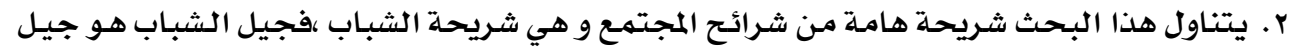

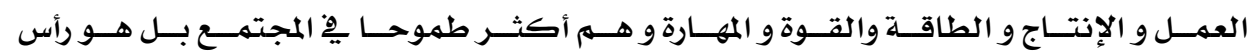
مال المجتمعات. r. يعد موضوع الرضا عن الحياة من الموضوعات الهامـة و التي تحتاج إلىي المزيـد مـن الدراسـات خاصـة

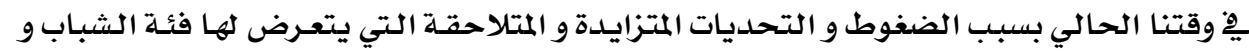

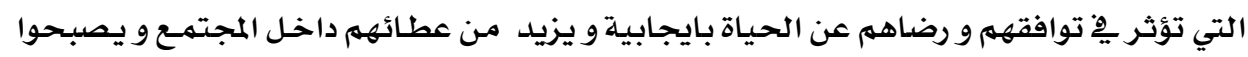
قوة منتجة .

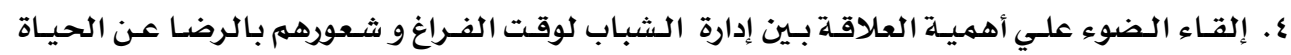

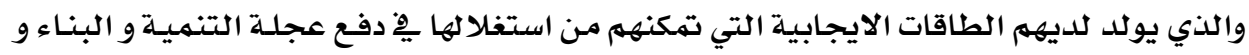

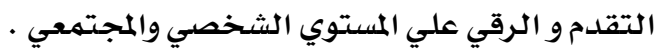




\section{בب إدارة الشباب لوقت الفراغ و علاقته بالرضا عن الحياة \\ الأسلوب البحثي \\ أولا : فروض البحث :}

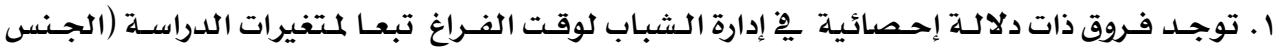

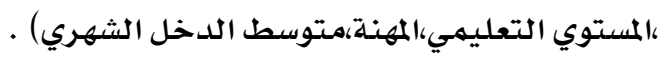

r. توجد فروق ذات دلالة إحصائية بين الشباب أفراد عينة البحث يِّ الرضـا عن الحيـاة تبعـا لمتغيرات

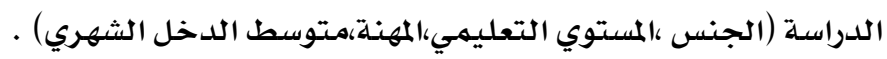

ץ. توجد علاقة ارتباطيه ذات دلالة إحصائية بـين إدارة الشبـاب لوقت الفـراغ بمحساوره وبـين الرضـا عن

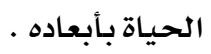

ع. توجد علاقة ارتباطيه ذات دلالة إحصائية بين إدارة وقت الفراغ بمحاوره و الرضا عن الحياة بأبعاده

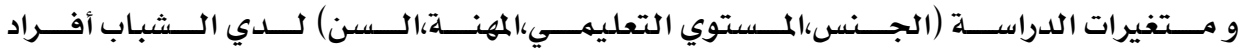

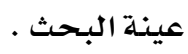

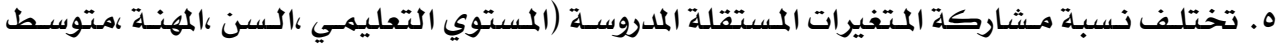

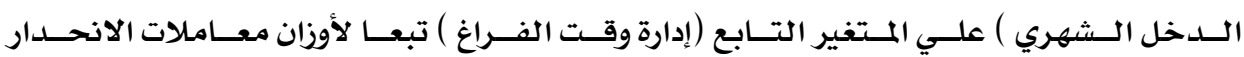

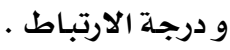

7. تختلف نسبة مسشاركة المتغيرات المستقلة المدروسـة (المهنسة ،المستوي التعليمسي ،متوسط الـدخل

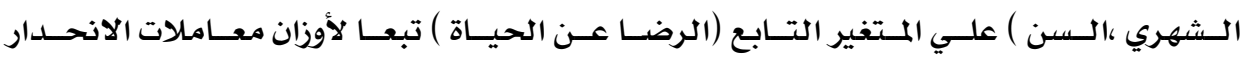

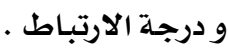

\section{منهفج البمث :}

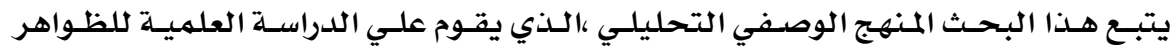

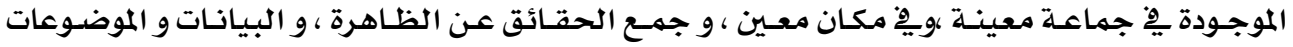

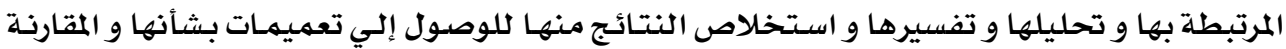

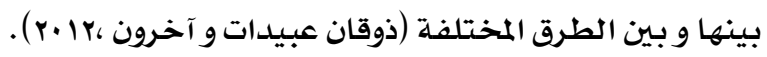

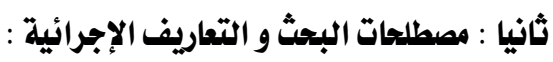

\section{Management : الإدارة}

تعرفها ايزيس نوارو آخـرون (1991) "بأنها مجموعـة مـن الطرق و الأسـاليب التي تستخدمام

كوسيلة لتحقيق أهداف معينة باستخدام موارد محددة باقصي درجة من آنسون الكفاءة " .

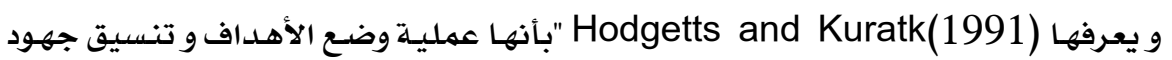

الأفراد من اجل تحقيق تلك الأهداف " .

و قد عرفتها كوثر كوجك (ه . r ) "بأنها عملية استغلال و استخدام الموارد المتوفرة للفرد

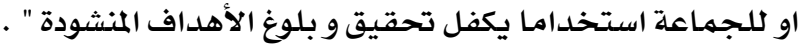




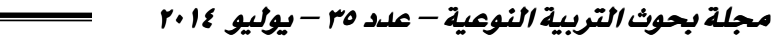

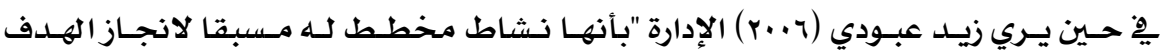

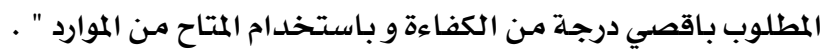

Youth : باب بابوي

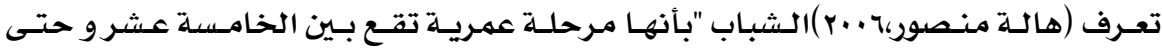

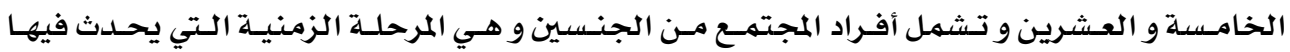

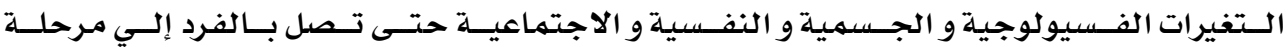

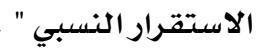

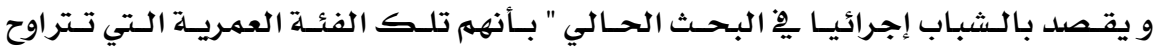

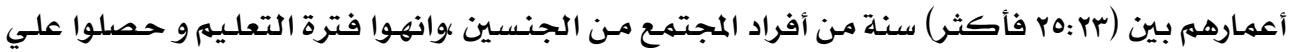

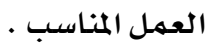

Time : الوقت الوعل

يعرف الوقت يْ اللغة "بأنه مقدار من الزمان قدر لأمـر ما " (المعجم الوسيط ،1917) .

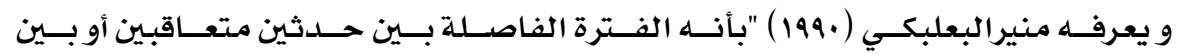
أحداث متعاقبـة " و

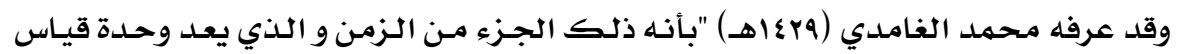

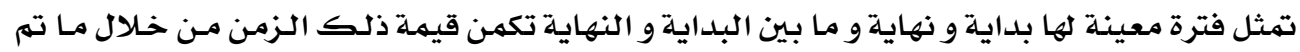

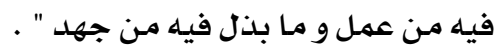

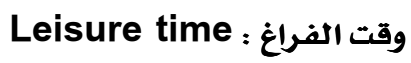

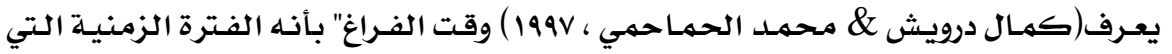

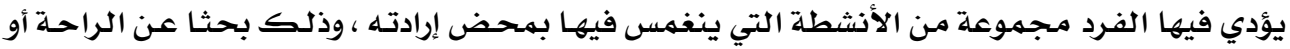

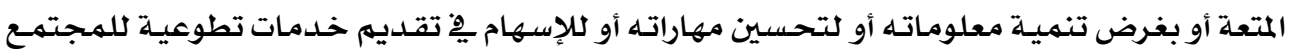

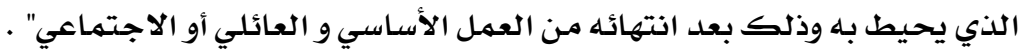

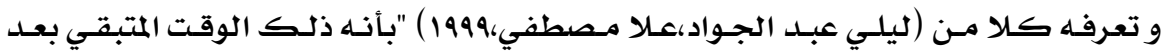

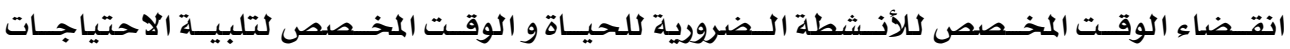

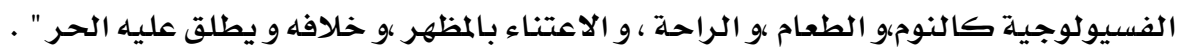

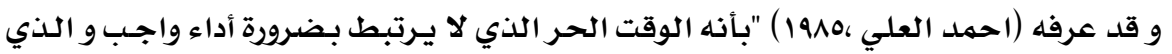

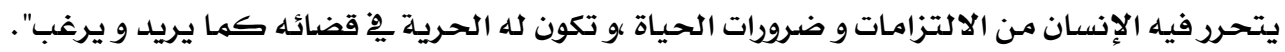

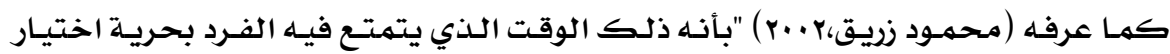
النشاط الذي يرغب يِّ ممارسته " . 


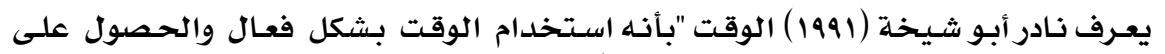

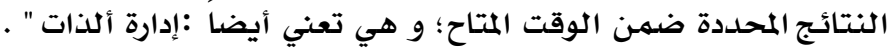

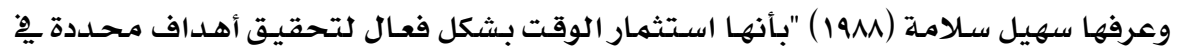

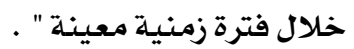

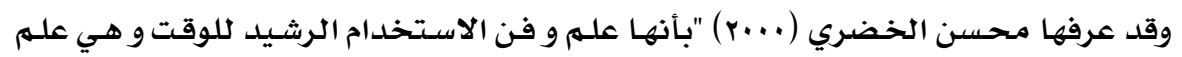

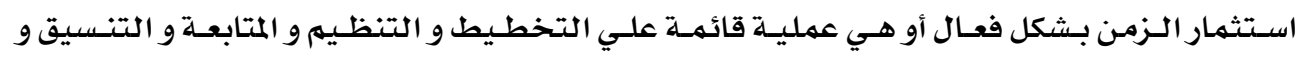

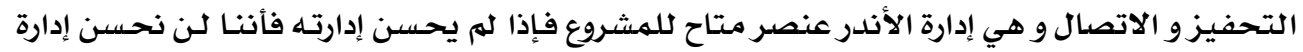

Management of Leisure time: إدارة وقت الفراغ "ن

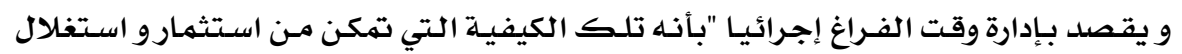

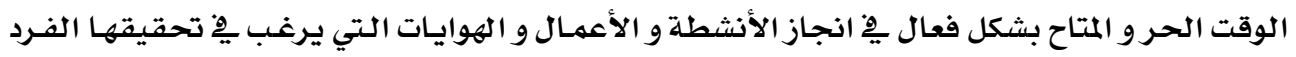

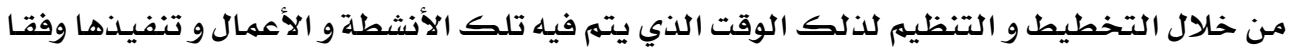

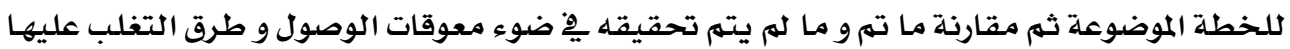
فيما بعد " .

Planning: التخطيط

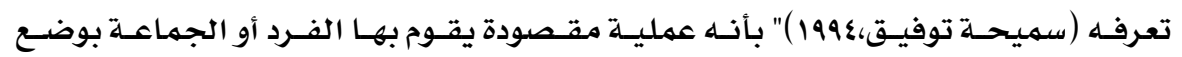

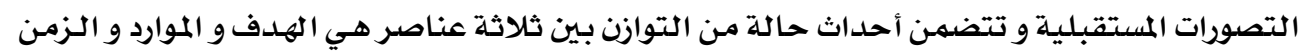

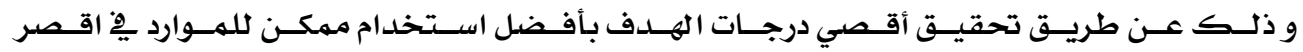

وقت مستطاع".

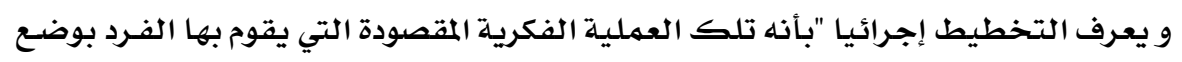

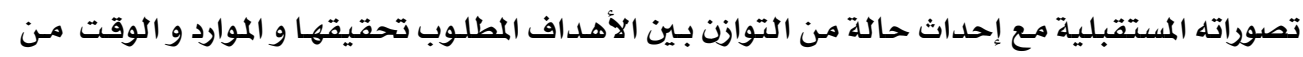

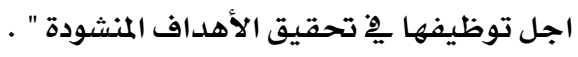

Implementation: التنفيذ توفيف

تعرفه (كوثر كوجك،1994) "بأنه احد مـراحل العمليـة الإداريـة التي تتحول فيها الخطـة

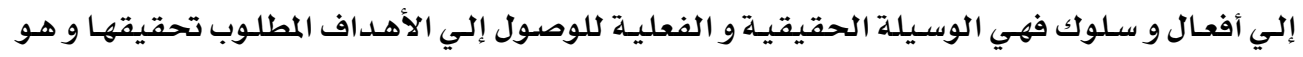

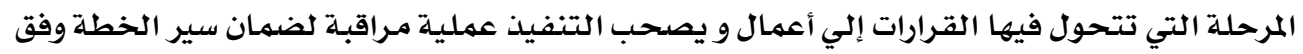

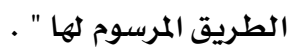

و يعرف التنفيـذ إجرائيـا "بأنه تلـك المرحلـة التي تتضمنها العمليـة الإداريـة و تتحهول فيها

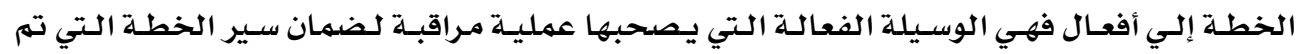

وضعها من اجل تحقيق الأهداف المنشودة " . 
Evaluation: التقييم

تعرفـه (وفاء شـلبي ،1999)"بأنـه القـــرة علـي تحليـل أي سـلوك أو عمـل و إعطاء حكـم واضـح

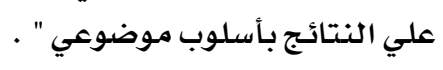

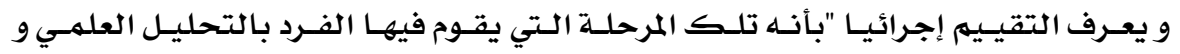

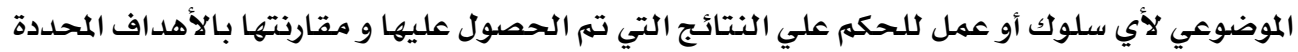

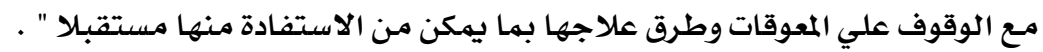

\section{Satisfaction: الرضا}

يعرف الرضا ِِّ صحيح البخاري "بأنه طيب النفس بما يصيبه ويفوته مـع عدم التغير" .

Life : الحياة

يعرف المعجهم الوسيط الحياة "بأنها النّموٌُو والبقاءُ " .

\section{Life satisfaction: الرضا عن الحياة}

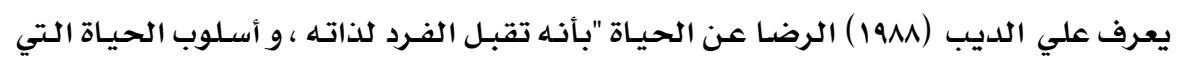

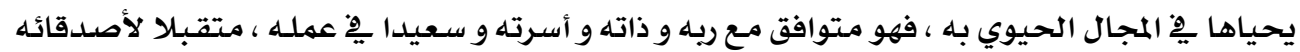

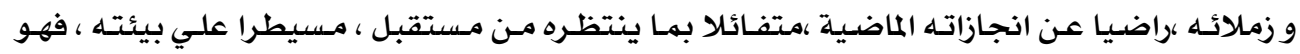
صاحب القرار ، قادرا علي تحقيق أهدافه " .

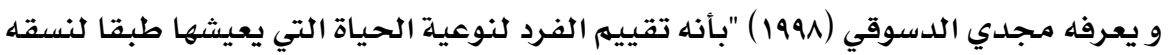

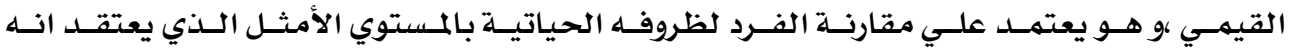

مناسب لحياته"

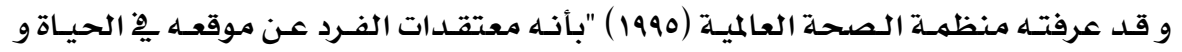

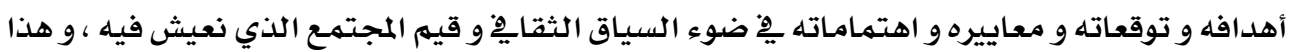

المفهوم يتأثر بكل مكونات البيئة التي نعيث فيها " (The Whoqol,1998) .

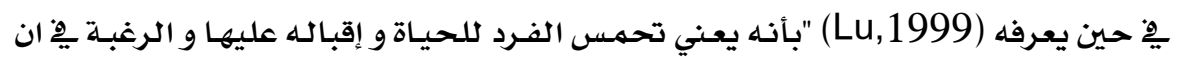

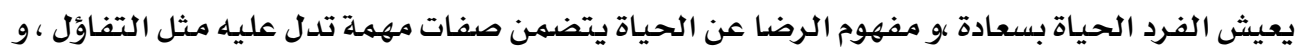

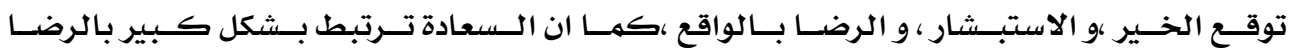

عن الحياة".

ويري Canada(2003 الرضا عن الحياة "بأنه الجزء الذاتي من نوعية الحياة ،فيـه يشعر

الفرد بالارتياح اتجاه وظائفه و ظروفه ووجوده " .

كمها يعرفه كـلا مـن (Gilligan\&Huebner,2002) "بأنـه تقيـيم الفـرد لمجـالات معينـة

" 


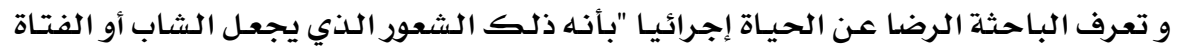

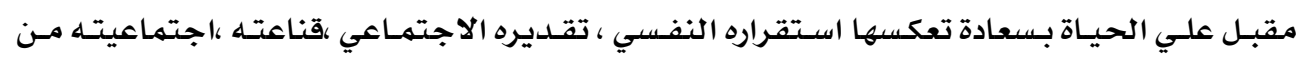

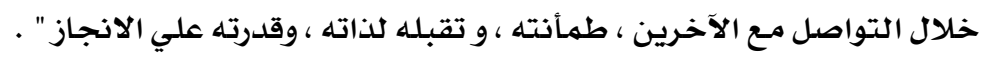
ثالثا : حلدود البحث :

يتحدد البحث فيما يلي :

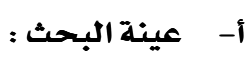

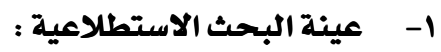

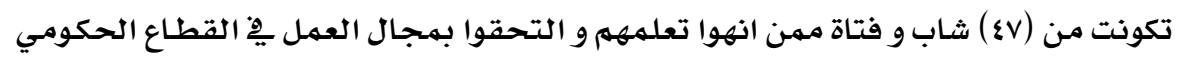

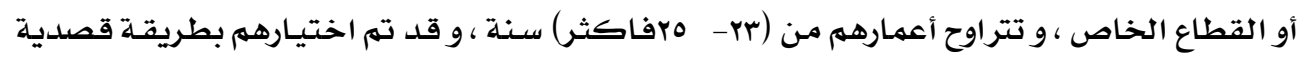

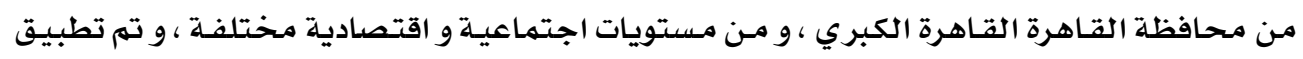

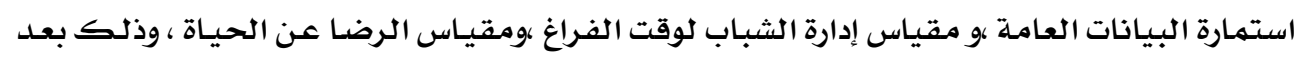

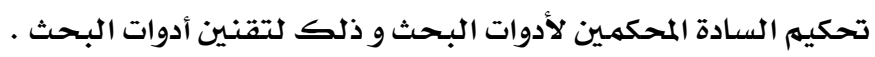

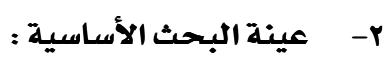

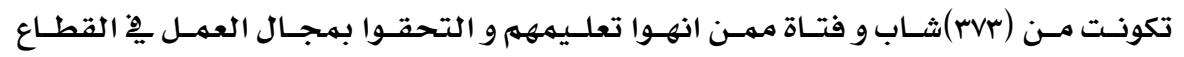

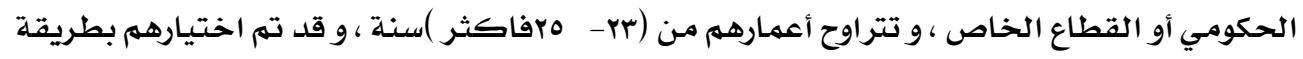

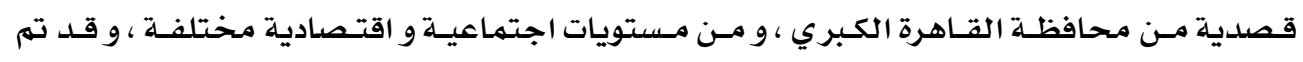

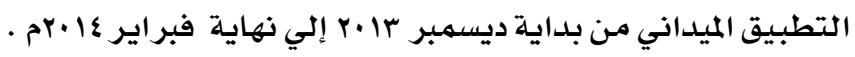

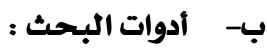

$$
\begin{aligned}
& \text { اشتملت أدوات البحث علي مـا يلي : } \\
& \text { ( ) (إعداد الباحثة ) } \\
& \text { 1- استمارة البيانات العامـة } \\
& \text { ( إعداد الباحثة ) }
\end{aligned}
$$

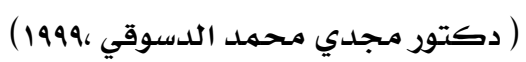

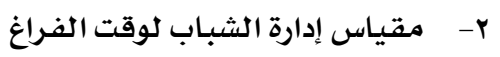

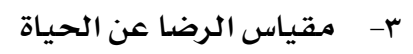

$$
\begin{aligned}
& \text { وصف أدوات البحث : }
\end{aligned}
$$

(إعداد الباحثة) ا - استمارة البيانات العامـة للشبـاب :

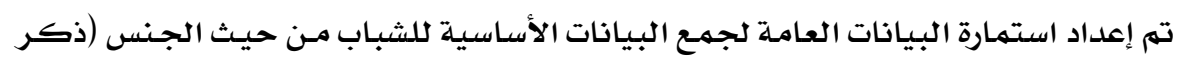

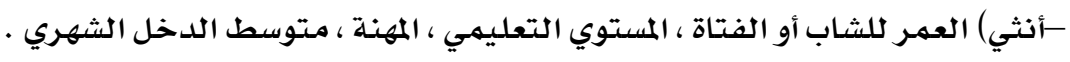




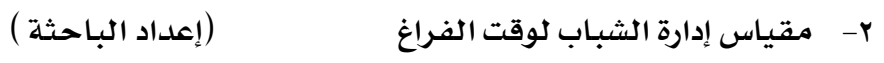

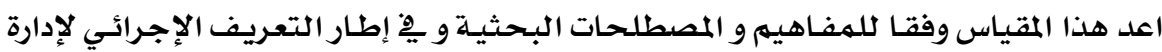

وقت الفراغ · و اشتمل مقياس إدارة الشباب لوقت الفراغ علي (هo)عبارة مقسمة إلي ثلاث محاور هي :

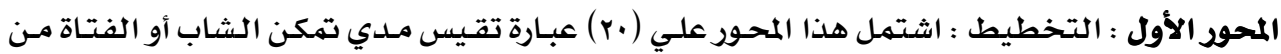

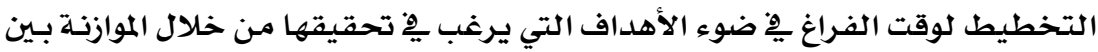

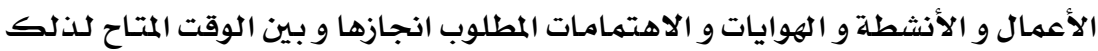

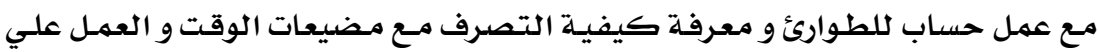

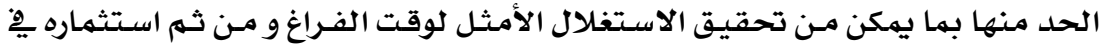

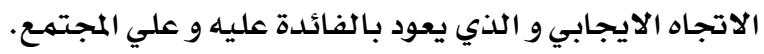

المحور الثاني :التتفيذ : اشتمل هذا المحور علي (IV) عبارة تشير إلي مـدي تمكن الشاب أو الفتاة مـن

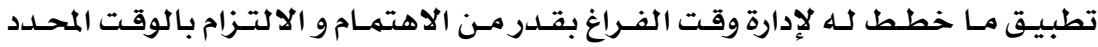

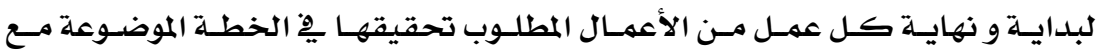

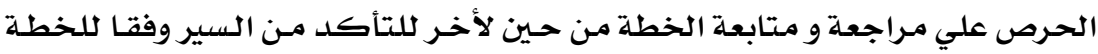

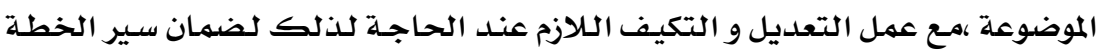

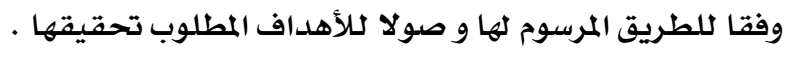

المحور الثالث :التقييه : اشتمل هذا المحور علي (19) عبارة تدور حول مدي تمكن الشاب أو الفتاة مـن

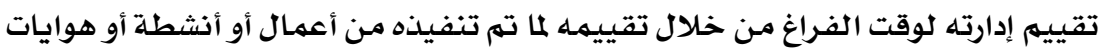

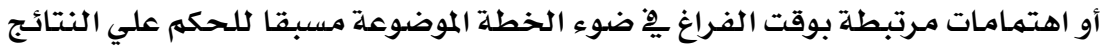

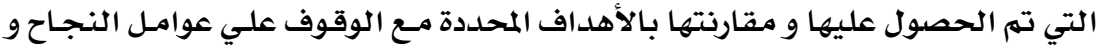

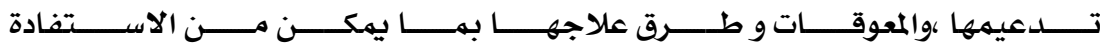

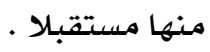

وقد تحددت الاستجابة علي المقياس وفقا للاختيار من ثلاث بدائل هي (نعمر، أحيانا ،نادرا )

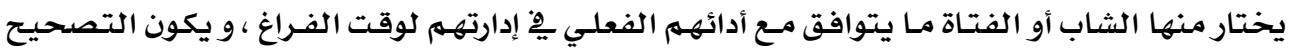

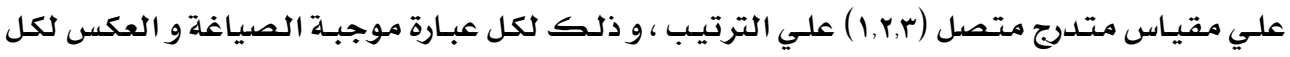

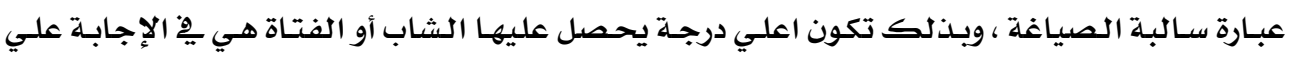

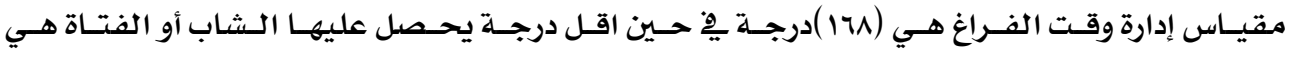

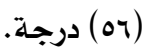
ثاثثا : مقياس الرضا عن الحياة :

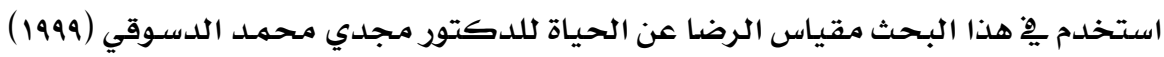

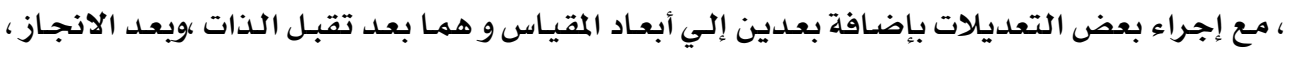




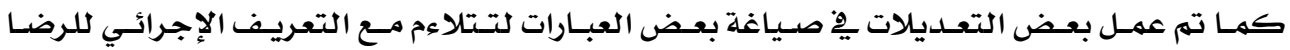
عن الحياة .

و الثـتمل المقيـاس علـي (0؟)عبـارة مقـسهـة إلىي ثمانيـة أبعـاد ، وهـذه العبـارات تعكس شعور

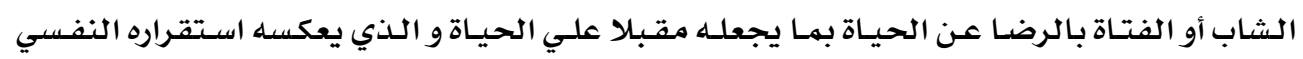

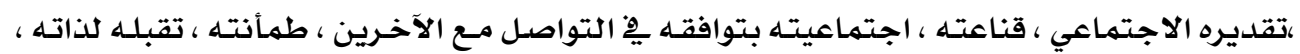
وأخيرا قدرته علي الانجـاز ،و فيما يلي وصف لأبعاد المقياس : البعد الأول : السعادة :

واشتمل هذا البعد علي (v) عبارات تعكس مدي شعور الشاب أو الفتاة بالبهجهة و الاستمتاع و

اللذة داخل الذات و ما يصحب ذلك من راحة نفسية تؤدي إلي التصالح مـع الذات و الآخرين .

البعد الثاني :الاستقرار النفسي :

واشتمل هذا البعد علي (ه) عبـارات تعكس مـدي شعور الشاب أو الفتـاة بثقتـه بذاته و شعوره

نحوها و فكره عن مدي أهميتها و توقعاته منها يِ مختلف مواقف الحياة .

البعد الثالث :التقدير الاجتماعي :

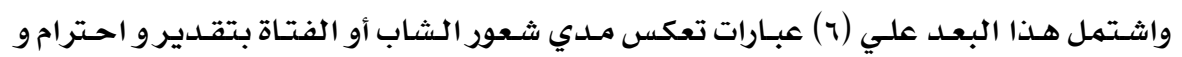

اعتبـار وثناء الآخرين له و النظرة الايجـابيـة له هِِ أي موقف مـن المواقف الحياتيـة و التتي يتفاعل فيها

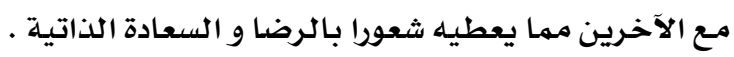
البعد الرابع :الثناعة :

واشتمل هذا البعد علي (ه) عبارات تعكس مدي شعور الشاب أو الفتاة بـالقبول و الرضـا لأي

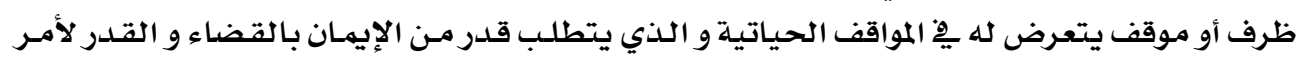
الله سبـحانه و تعالي ويجعله يحي حيـاة طيبـة . البعد الخامس :الاجتماعية :

واشتهل هذا البعد علي (0) عبـارات تعكس مـدي شعور الشـاب أو الفتـاة بـالرضـا عن العلاققات الاجتماعية التي تحدث بينـه و بين من يتفاعل معهم يِ المواقف الحياتية سواء علي المستوي الشخصي أو علي المستوي الأسـري أو مستوي مـجال العمل و التي تتسـهم بالتوافق و الانســام الناجمـان عن نجـاح العلاققات الاجتتماعية . البعد السادس :الطمأنينة : واشتمل هذا البعد علي (7) عبارات تعكس مدي شعور الشاب أو الفتاة بقيمتـه و طمأنته إلىي

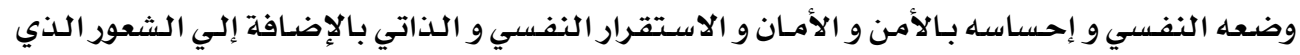
يحصل عليه من التقدير و التشجيع من الآخرين بالإضافة إلي تحرره من الخوف . 
البعد السابع :تقبل الذات : 2 البع

واشتمل هذا البعد علي (ه) عبارات تعكس مدلي شعور الشاب أو الفتاة بتقبله لذاته من خلالال

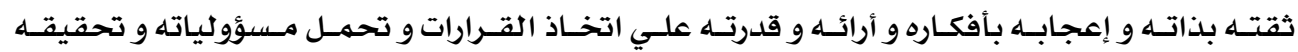

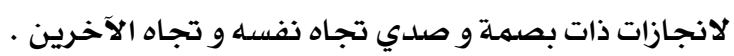
البعد الثامن :الانجاز :

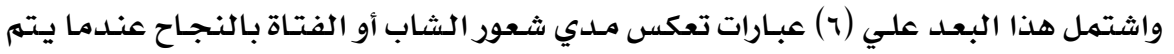

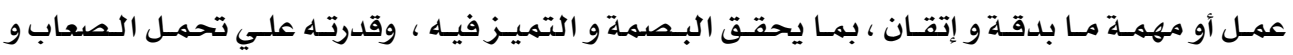

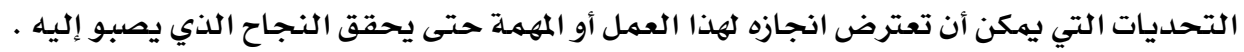

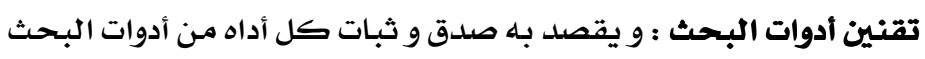

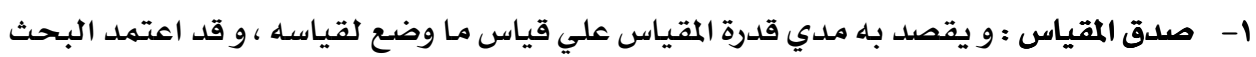

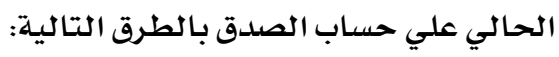

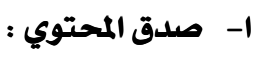

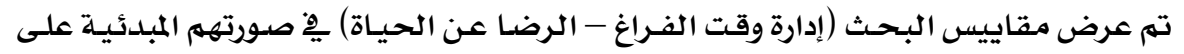

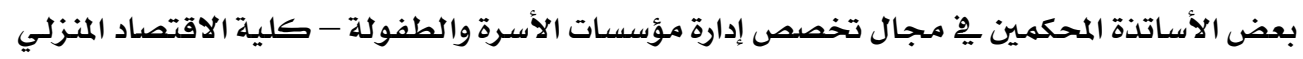

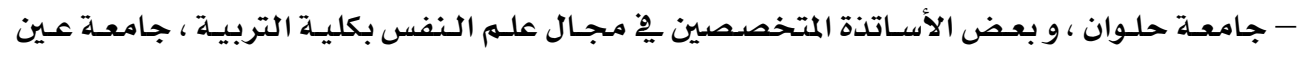

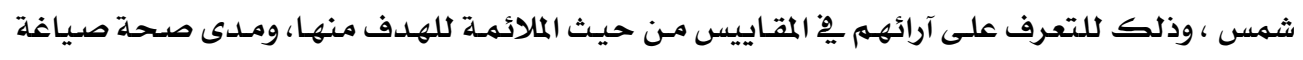

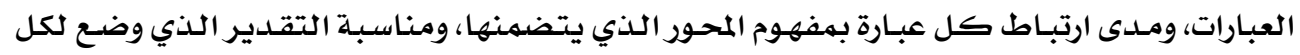

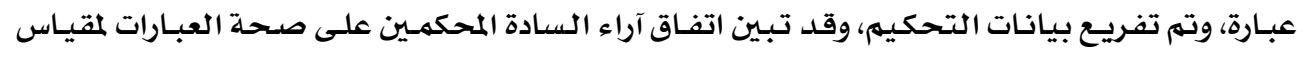

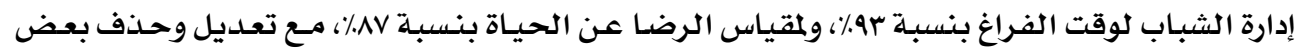

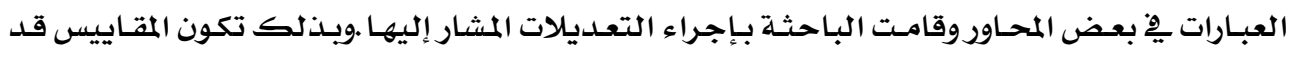
خضعت لصدق المحتوي .

\section{الاتساق الداخلي :}

وذلك عن طريق حساب معامـل ارتبـاط بيرسـون لكل مقياس مـن مقـاييس البـحث حيث تم

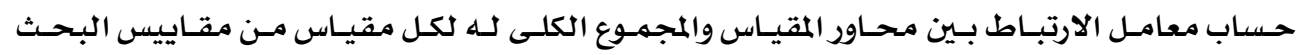

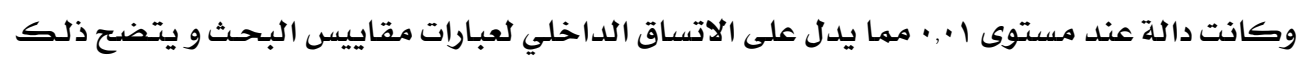

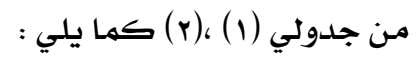


جدول (1) معامل الارتباط بين الدرجة الكلية لكل محور

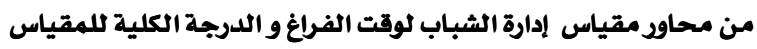

\begin{tabular}{|c|c|c|}
\hline 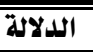 & الارتباط & محاور مقياس إدارة الشباب لوقت الفراغ \\
\hline$\cdot,+1$ & $\cdot, 917$ & المحور الأول : التخطيط \\
\hline$\cdot,+1$ & $\cdot, \mathrm{YOI}$ & المحور الثاني : التنفيذ \\
\hline$\cdot,+1$ & $\cdot$, Arr & المحور الثالثُ : التقيييه \\
\hline
\end{tabular}

يتضـح مـن جـدولي (1) أن قيهم معـاملات ارتبـاط محساور مقيـاس إدارة الدذات و الدرجـة الكليـة

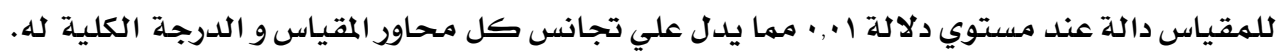
جدول (r) معامل الارتباط بين الدرجة الكلية لكل بعد من أبعاد مقياس الرضا عن الحياة و الدرجة الكلية للمقياس

\begin{tabular}{|c|c|c|}
\hline الدلالة & الارتباط & ابعاد مقياس الرضا عن الحياة \\
\hline$\cdot, \cdot 1$ & •, $\vee$. & البعد الأول : السعادة \\
\hline$\cdot, \cdot 1$ & $\cdot, \wedge V I$ & البعد الثاني : الاستقرار النفسي \\
\hline$\cdot, \cdot 1$ & $\cdot, q \cdot r$ & البعد الثالث : التقدير الاجتماعي \\
\hline$\cdot, \cdot 1$ & •, VYA & البعل الرابع : الثناعة \\
\hline$\cdot, \cdot 1$ & $\cdot, 190$ & البعد الخامس : الاجتماعية \\
\hline$\cdot, \cdot 1$ & $\cdot, 940$ & البعد السادس : الطمأنينة \\
\hline$\cdot, \cdot 1$ & $\cdot, \vee 71$ & المحور السابع : تقبل الذات \\
\hline$\cdot,+1$ & $\cdot, \wedge \leqslant Y$ & المحور الثامن : الإنجاز \\
\hline
\end{tabular}

يتضـح مـن جـدولي (r) أن قيهم معـاملات ارتبـاط محساور مقيـاس الرضـا عن الحيـاة و الدرجـة

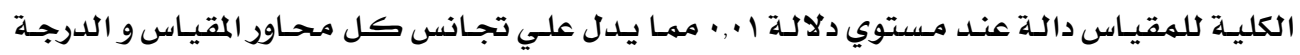
الكلية له .

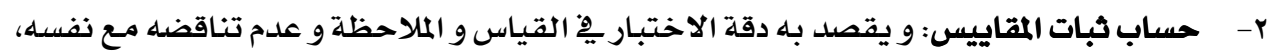
و اتساقه فيما يزودنا به من معلومات عن سلوك المفحوص (أمال صـادق ،فؤاد أبو حطب ، 1991) ).

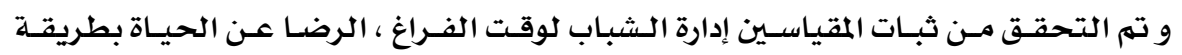

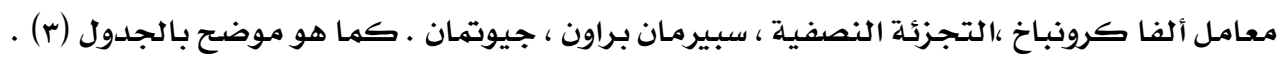


جدول (r) معامل الثبات لأدوات الدراسة

\begin{tabular}{|c|c|c|c|c|}
\hline جيوتمان & سبيرمان براوز & التجزئة النصفية & معامل الفا & محاور مقياس إدارة الشباب لوقت الفراغ \\
\hline$\cdot, \wedge \wedge \wedge$ & $\cdot$, arr & $\cdot, \wedge \uparrow$ & $\cdot, q \cdot v$ & المحور الأول : التخطيط \\
\hline •, VYr & $\cdot, r \vee 1$ & $\cdot, Y \cdot r$ & $\cdot, \mathrm{V} \leqslant \wedge$ & المحور الثاني : التنفيذ \\
\hline 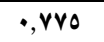 & •,AY. & $\cdot, \mathrm{Y} 00$ & $\cdot, \vee \vee 90$ & المحور الثالث : التقييي \\
\hline$\cdot, 117$ & $\cdot, 170$ & •, $\vee$ 91 & •,Arr & ثبات الاستبيان ككل \\
\hline جيوتثان & سبيرمان براوز & التجزئة النصفية & معامل الفا & أبعاد مقياس الرضا عن الحياة \\
\hline$\cdot 9 \mathrm{Mr}$ & $\cdot, 901$ & $\cdot, 191$ & $\cdot, 9$ 9ro & المحور الأول : السعادة \\
\hline$\cdot, \vee \wedge \wedge$ & •, ATr & $\cdot$, VAr & $\cdot, \wedge \cdot \bullet$ & المحور الثاني : الاستقرار النفسي \\
\hline$\cdot, \mathrm{VIT}$ & $\cdot$, VIr & $\cdot, 799$ & •, YY६ & المحور الثالث : التقدير الاجتماعي \\
\hline$\cdot, \wedge 79$ & $\cdot, 918$ & $\cdot, \wedge \leqslant \varepsilon$ & $\cdot, \wedge \wedge \varepsilon$ & المحور الرابع : القناعة \\
\hline$\cdot, 9 \cdot \cdot$ & $\cdot, 9 \xi \bullet$ & $\cdot$, AVO & $\cdot, 91 r$ & المحور الخامس : الاجتماعية \\
\hline$\cdot, \mathrm{V} \leqslant \wedge$ & •, V99 & •,VYr & $\cdot, \vee \vee 11$ & المحور السادس : الطمأنينة \\
\hline$\cdot$, Aro & •, AYo & $\cdot, \Lambda \cdot r$ & $\cdot, \wedge \leqslant 1$ & المحور السابع : تقبل الذات \\
\hline$\cdot, 917$ & $\cdot, 901$ & $\cdot, \wedge \wedge 1$ & $\cdot, 9 Y \xi$ & المحور الثامن : الإنجاز \\
\hline$\cdot, \wedge \leqslant 9$ & $\cdot, \wedge 99$ & $\cdot, \Lambda Y r$ & $\cdot, \wedge 77$ & ثبات الاستبيان ككل \\
\hline
\end{tabular}

يتضح من جدولي (r) أن جميع قيم معامل الثبات لمقاييس أدوات البحث (إدارة الشباب لوقت

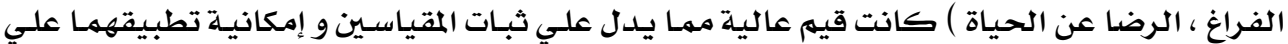

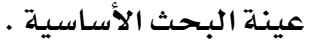

المعالجات الإحصائية:

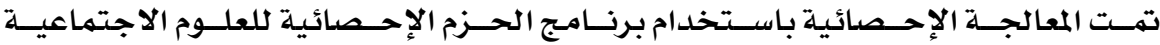
Statistical Package For Social Program SPSS عن العلاقة بين متغيرات الدراسـة ،وقد تمت المعالجات الإحصائية التالية : 1- حساب الصدق لأدوات البحث لحساب الاتساق الداخلي باستخدام معامل ارتباط بيرسون.

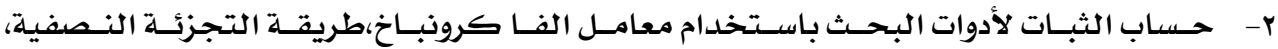
سبيرمان، و جيوتمان التبان لانوات r- حساب النسب المئوية و التوزيعات التكرارية لوصف عينة البحث .

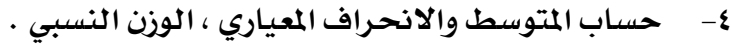
ه- تحليل التبـاين Analysis of Variance (ANOVA) الأحسادي لمعرفة دلالـة الفـروق بـين

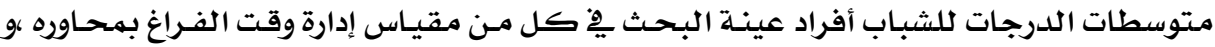

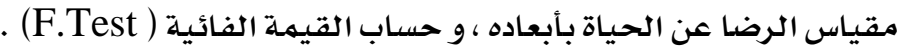

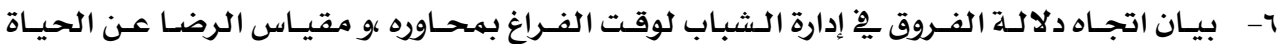

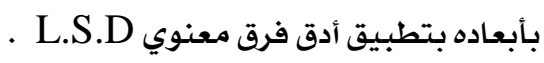

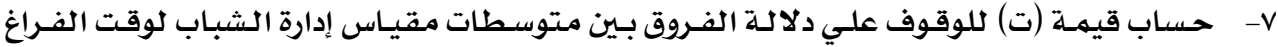

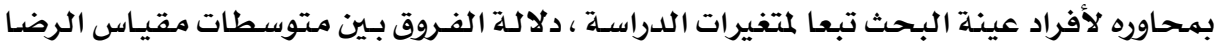


عن الحيـاة لأفراد عينـة البحـث تبعـا لمتغيرات الدراسـة باسـتخدام اختبـار (T.Test) للمستغيرات ثنائية الأبعاد.

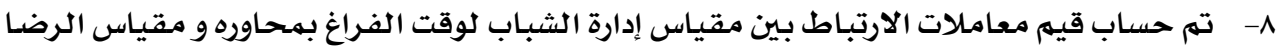

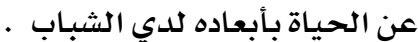

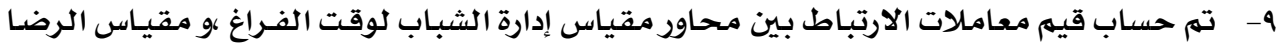

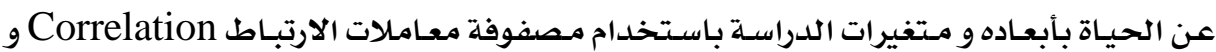

\section{نتائج البحث تهليلها وتفسيرهئ}

أولاً: النتائج الوصفية:

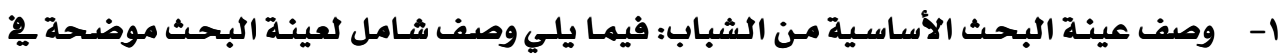

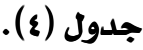

\begin{tabular}{|c|c|c|}
\hline$(r V r=0)$ & \multicolumn{2}{|c|}{ جدول (ع) وصف عينة البحث الأساسية } \\
\hline النسبة. & العدد & الجنس \\
\hline$\% r q, q$ & $1 \leqslant 9$ & زكر \\
\hline$\% .7 \cdot, 1$ & TYE & أثثي \\
\hline$\% 1 \cdots$ & rVr & المجموع \\
\hline النسبة. & العلدد & المستوي التعليمي \\
\hline$\%$ Y $\{, 1$ & 9. & منخفض \\
\hline$\% r r, Y$ & IrY & متوسط \\
\hline$\%$ \% Y,Y & 171 & عالي \\
\hline$\% 1 \cdots$ & rVY & المجموع \\
\hline النسبة. & العلد & المهنة \\
\hline$\%$ rY,r & 91 & دنيا \\
\hline$\%$ & 111 & متوسطة \\
\hline$\% \leqslant Y, 1$ & 10Y & عليا \\
\hline$\% 1 \cdots$ & rVY & المجموع \\
\hline النسبة. & العلد & السن \\
\hline$\%$ rr, I & 17 & أقل من rr سنة \\
\hline$\%$ \%१, & IV & مز rr سنة إلي ب سنة \\
\hline$\% r \cdot r$ & $11 \%$ & مز مب سنة فأكثر \\
\hline$\% 1+$. & rrr & المجموع \\
\hline النسبة. & العلد & الدخل الشهري \\
\hline$\% \mathbf{Y A}, \boldsymbol{Z}$ & 1.7 & منخفض \\
\hline$\% \mu, \Lambda$ & 110 & متوسط \\
\hline$\%$ & $10 Y$ & مرتفع \\
\hline$\% 1 \cdots$ & rVY & المجموع \\
\hline
\end{tabular}

\section{يتضح من جدول (ع) ما يلى:}

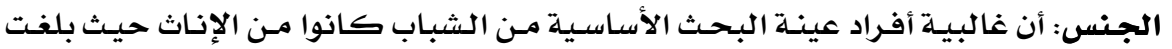

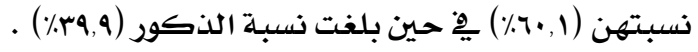




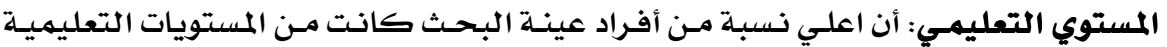

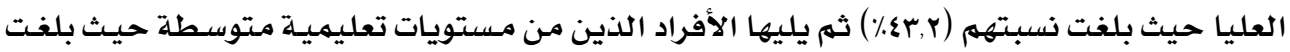

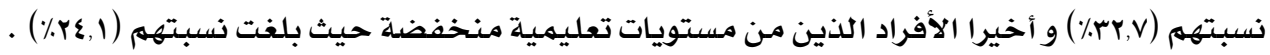

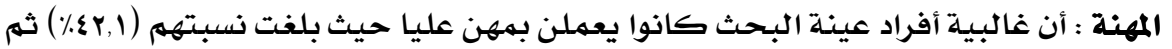

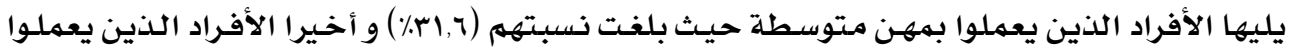

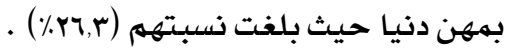

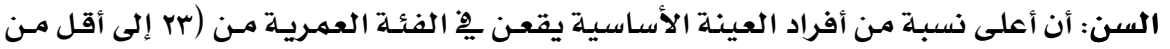

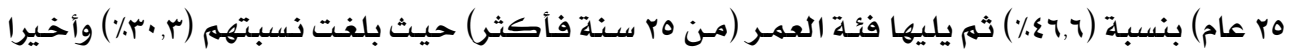

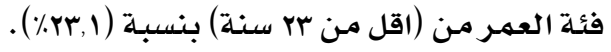
متوسط الدخل الشهري : أن غالبية أفراد عينة البحث كانوا من مستويات مرتفعة للدخول

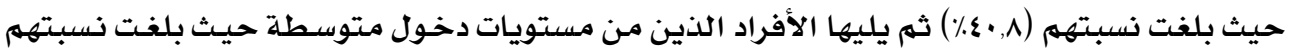

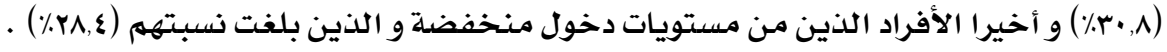
r- تختلف الأوزان النسبية لأبعاد الرضا عن الحياة لدي الشباب عينة البحث الأساسية : جدول (ه) الأوزان النسبية لأبعاد الرضا عن الحياة لدي الشباب عينة البحث الأساسية

\begin{tabular}{|c|c|c|c|}
\hline الترتيب & النسبة المئوية./ & الوزن النسبي & أبعاد الرضا عن الحياة \\
\hline الخامس & $\% / r, 1$ & हTA & السعادة \\
\hline الثاني & $\%$ & $\{\wedge \mid$ & الاستقرار النفسي \\
\hline السابع - الس & $\%: 11, \xi$ & $\xi . r$ & التقلدير الاجتماعي \\
\hline 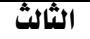 & $\%$ & \$7T & القناعة \\
\hline الثامن & $\%$ & rA乏 & الاجتماعية \\
\hline الرابع - الرابع & $\% 1 r, 7$ & $\xi \$ 0$ & الطمأنينة \\
\hline الأول & $\% 1 \xi, r$ & $0 . \xi$ & تقبل الذات \\
\hline السادس & $\% 11,9$ & $\$ 19$ & الإنجاز \\
\hline & $\% 100$ & rory & المجموع \\
\hline
\end{tabular}

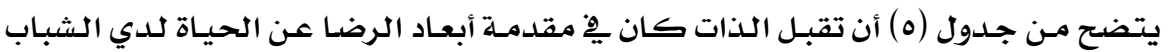

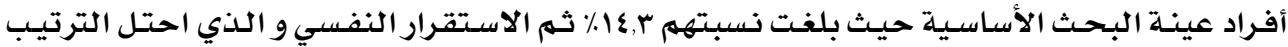

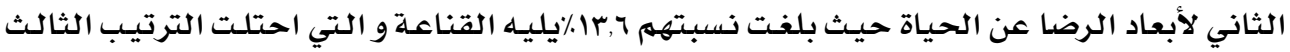

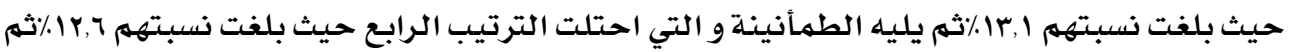

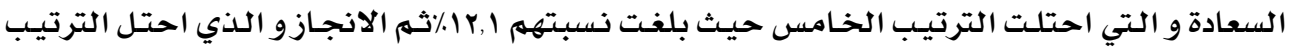

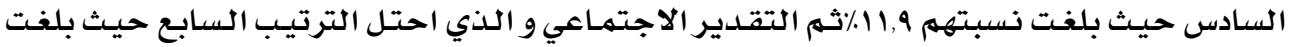

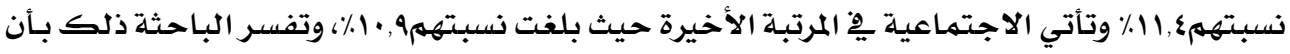

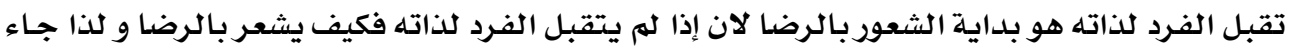

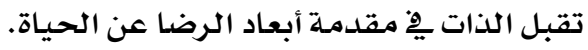




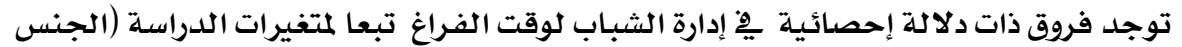

$$
\text { ، ولامستوي التعليمي،المهنة،متوسط الدخل الشهري) . }
$$

أ- اختبار (ت) للوقوف على دلالة الفروق بين متوسطات إدارة الشباب لوقت الفراغ (تخطيط ،تنفيذ

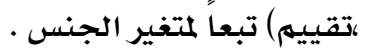

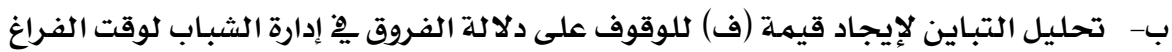

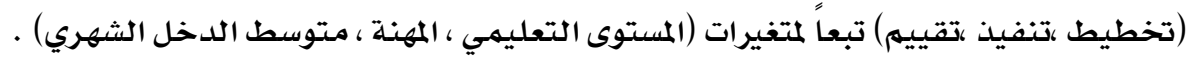

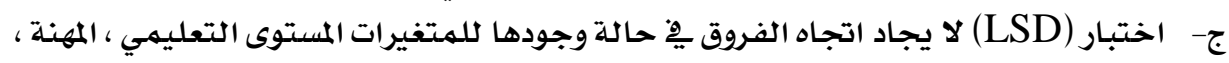

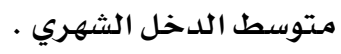

\begin{tabular}{|c|c|c|c|c|c|c|c|}
\hline الدلالة & قيهة (ت) & الحرية & العينة & الانحراف & الحسابي & الجنس & مقت الفراغ \\
\hline \multirow{2}{*}{ لصال عند الذكور } & \multirow{2}{*}{24.256} & \multirow{2}{*}{371} & 149 & 5.583 & 52.040 & ذكور & \multirow{2}{*}{ التخطيط } \\
\hline & & & 224 & 8.213 & 33.375 & إناث & \\
\hline الدلالة & قيمة (ت) & الحرية & العينة & الانحراف & الحتوسط الحسبي & الجنس & \multirow{3}{*}{ التنفيذ } \\
\hline \multirow{2}{*}{ لصال عند الإناث 0.01} & \multirow{2}{*}{25.484} & \multirow{2}{*}{371} & 149 & 5.990 & 26.268 & ذكور & \\
\hline & & & 224 & 6.214 & 42.772 & إناث & \\
\hline الدلالة & قيمة (ت) & الحرية & العينة & الانحراف & الحتوسط الحسبي & الجنس & \multirow{3}{*}{ التقييي } \\
\hline \multirow{2}{*}{ دال عند الإناث 0.01} & \multirow{2}{*}{23.687} & \multirow{2}{*}{371} & 149 & 5.787 & 28.033 & ذكور & \\
\hline & & & 224 & 6.564 & 45.049 & إناث & \\
\hline
\end{tabular}

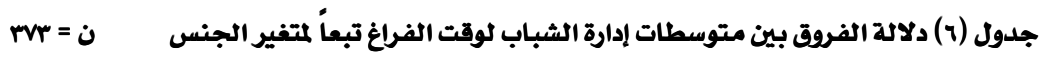

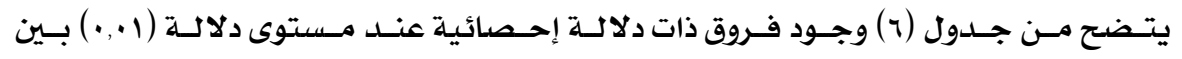

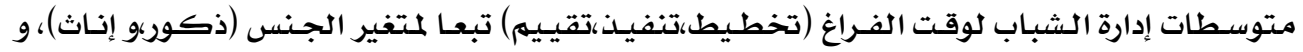

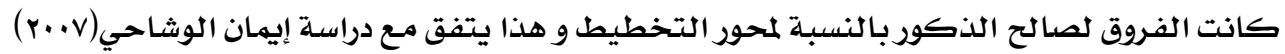

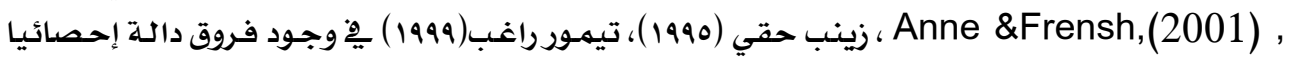

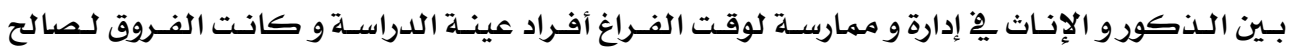

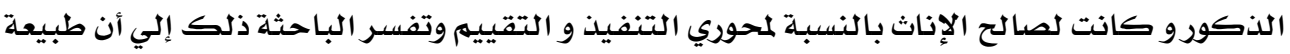

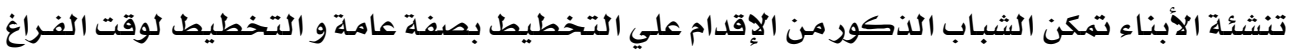

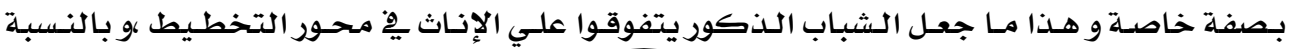




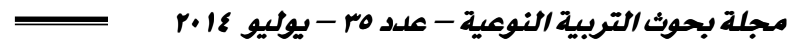

لمحوري التنفيذ و التقييم كانت الإناث تتفوقن فيه علي الذكور لطبيعة الإناث يِّا الإسـراع بالتنفيذ

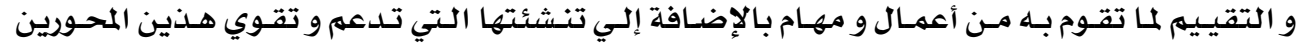

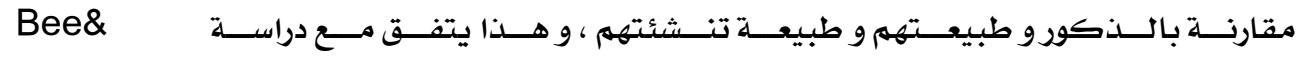
Ronaghy(1990), Trueman \&Hartley(1996)

\begin{tabular}{|c|c|c|c|c|c|c|}
\hline اللدلالة & قيمة ( ف) & الدرجات & متوسط المربعات & مجموع المربعات & التعليمي & $\begin{array}{c}\text { محاور إدارة وقراغ } \\
\text { الفراغ }\end{array}$ \\
\hline \multirow{3}{*}{0.01 دار } & \multirow{2}{*}{44.771} & 2 & 15704.756 & 31409.513 & المجموعات & \multirow{3}{*}{ التخطيط } \\
\hline & & 370 & 350.777 & 129787.388 & المجموعات & \\
\hline & & 372 & & 161196.901 & المجموع & \\
\hline الدلالة & قيمة (ف) & الدرجات & متوسط المربعات & مجموع المربعات & التعليمي & \multirow{4}{*}{ التنفيذ } \\
\hline \multirow{3}{*}{0.01 دار } & \multirow{2}{*}{47.327} & 2 & 12216.504 & 24433.008 & المجموعات & \\
\hline & & 370 & 258.132 & 95508.992 & المجموعات & \\
\hline & & 372 & & 119942.000 & المجموع & \\
\hline الدلالة & قيمة ( ف) & الحرجية & متوسط المربعات & مجموع المربعات & التعليمي & \multirow{4}{*}{ التقييي } \\
\hline \multirow{3}{*}{0.01 دار } & \multirow{2}{*}{35.477} & 2 & 10321.816 & 20643.631 & المجموعات & \\
\hline & & 370 & 290.947 & 107650.401 & المجموعات & \\
\hline & & 372 & & 128294.032 & المجموع & \\
\hline
\end{tabular}

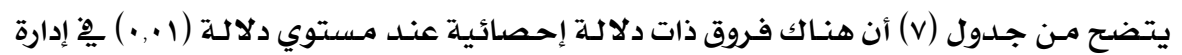

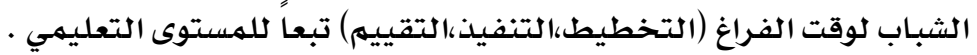

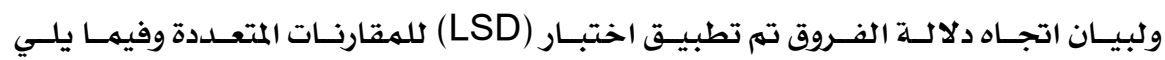
بيان ذلك. 


\begin{tabular}{|c|c|c|c|c|}
\hline م = عالي & م = متوسط & م = منخفض 25.144 & المستوي التعليهي & محاور إدارة الفراغ \\
\hline & & - & منخفض & \multirow[t]{3}{*}{ التخطيط } \\
\hline & - & $* * 13.109$ & متوسط & \\
\hline- & $* * 13.298$ & $* * 26.408$ & عالي & \\
\hline \multirow{4}{*}{ 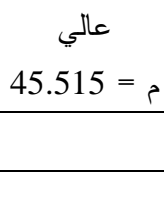 } & متوسط & منخفض & الإتبىى التعلبمي & \multirow{5}{*}{ التنفيذ } \\
\hline & $34.213=$ & $22.144=$ & - & \\
\hline & & - & & \\
\hline & - & $* * 12.068$ & متوسط & \\
\hline- & $* * 11.302$ & $* * 23.371$ & عالي & \\
\hline \multirow{4}{*}{ م = عالي = } & منوسط & منخفض & المستوي التعليمي & \multirow{5}{*}{ التقييي } \\
\hline & $32.163=$ & م $29.822=$ & & \\
\hline & & - & منخفض & \\
\hline & - & $* 2.341$ & متوسط & \\
\hline- & $* * 15.413$ & $* * 17.755$ & عالي & \\
\hline
\end{tabular}

بدون نجوم غير دال

0.05 * دال عند

0.01 \&

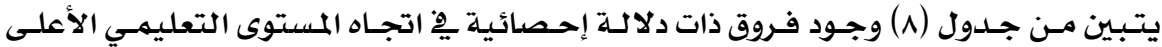

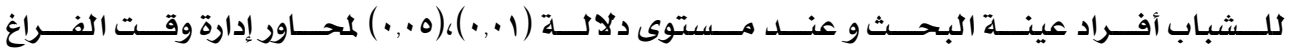
(التخطيط،التنفيذ،التقييهم) ، وتفسر الباحثة ذلك إلى أنه كلهـا ارتفـع المستوى التعليهـي للشبـاب

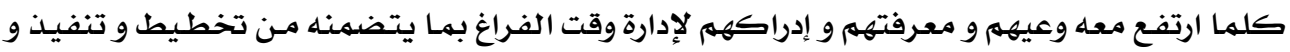
تقييم أي أن هناك تناسب طردي بـين المستوي التعليهي للشبـاب و بين إدارتهم لوقت الفـراغ مهـا يعكس الآثار الايجابيـة للتعليهم علي إدارة الشبـاب لوقت الفـراغو انـه كلهـا ارتقي المستوي التعليهـي للشبـاب

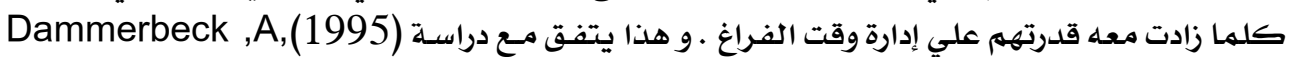
، Elke Zeijl \&Yolanda To Elke Elke Zeijl \&Others(2000)، (1999) عبير أنورة (1920)، Anderssen \& Oygard (1998)

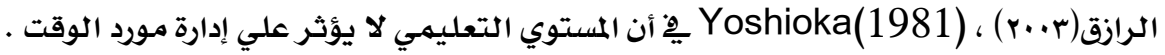




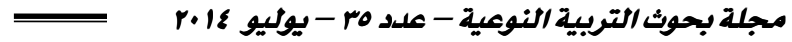

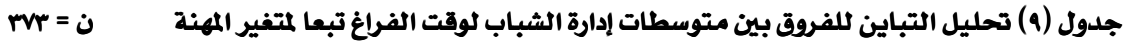

\begin{tabular}{|c|c|c|c|c|c|c|}
\hline الدلالة & قيمة ( ف) & درجات الحرية & متوسط المربعات & مجموع المربعات & المهنة & مقت الفراغ إدارة \\
\hline \multirow{3}{*}{0.01 دال } & \multirow{2}{*}{54.540} & 2 & 11339.371 & 22678.742 & بين المجموعات & \multirow[t]{3}{*}{ التخطيط } \\
\hline & & 370 & 207.910 & 76926.765 & داخل المجموعات & \\
\hline & & 372 & & 99605.507 & المجموع & \\
\hline الدلالة & قيمة (ف) & درجات الحرية & متوسط المربعات & مجهوع المربعات & المهنة & \multirow{4}{*}{ التنفيذ } \\
\hline \multirow[t]{3}{*}{0.01 دال } & 46.897 & 2 & 8143.719 & 16287.439 & بين المجموعات & \\
\hline & & 370 & 173.652 & 64251.119 & داخل المجهوعات & \\
\hline & & 372 & & 80538.558 & المجموع & \\
\hline الدلالة & قيمة (ف) & درجات الحرية & متوسط المربعات & مجموع المربعات & المهنة & \multirow{4}{*}{ التقييي } \\
\hline \multirow[t]{3}{*}{0.01 دال } & 48.937 & 2 & 8962.691 & 17925.382 & بين المجموعات & \\
\hline & & 370 & 183.147 & 67764.397 & داخل المجموعات & \\
\hline & & 372 & & 85689.779 & المجموع & \\
\hline
\end{tabular}

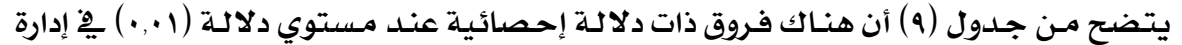

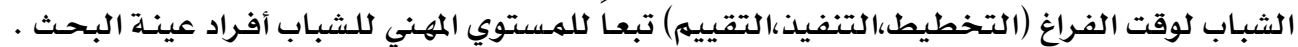

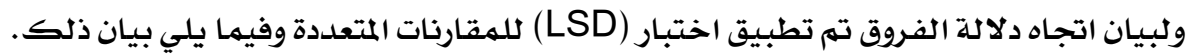

جدول ( • ) دلالة الفروق بين إدارة الشباب لوقت الفراغ تبعا لمتغير المهنة

\begin{tabular}{|c|c|c|c|c|}
\hline 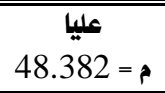 & م = متوسطة & 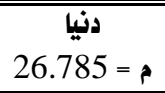 & المهنة & مقاور إدارة \\
\hline & & - & دنيا & \multirow{3}{*}{ التخطيط } \\
\hline & - & $* * 15.663$ & متوسطة & \\
\hline- & $* * 5.933$ & **21.596 & عليا & \\
\hline \multirow{4}{*}{ 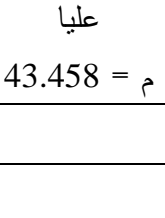 } & منوسطة & دنيا & at & \multirow{4}{*}{ التنفيذ } \\
\hline & $35.745=$ & م $25.040=$ & & \\
\hline & & - & دنيا & \\
\hline & - & $* * 10.704$ & متوسطة & \\
\hline- & $* * 7.712$ & ** 18.417 & عليا & \\
\hline \multirow{4}{*}{ 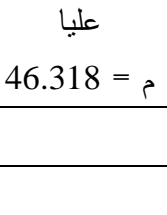 } & منوسطة & دنيا & ت & \multirow{5}{*}{ التقييي } \\
\hline & ? $36.550=$ & $27.377=$ & & \\
\hline & & - & دنيا & \\
\hline & - & $* * 9.173$ & متوسطة & \\
\hline- & $* * 9.767$ & $* * 18.940$ & عليا & \\
\hline
\end{tabular}




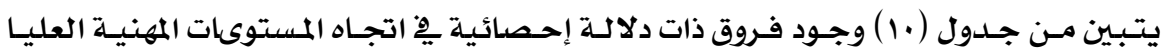

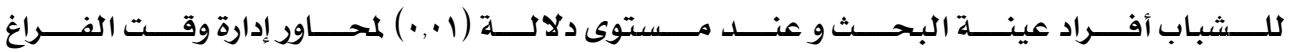

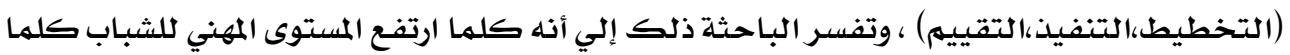

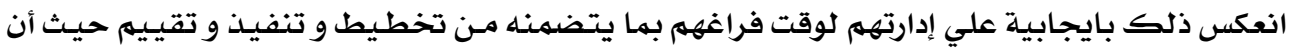

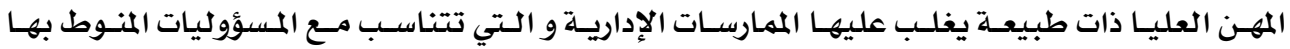

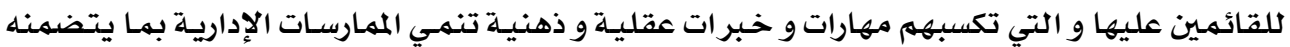

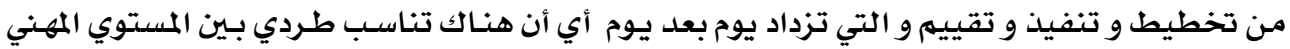

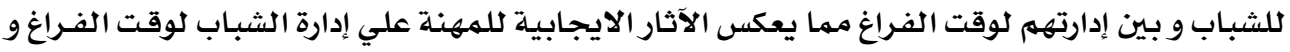

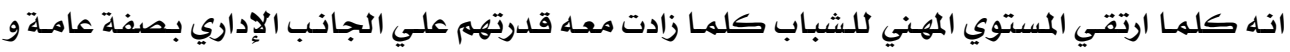

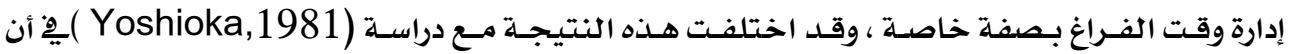

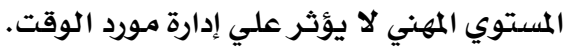

جدول (11) تحليل التباين للفروق بين متوسطات إدارة الشباب التودي

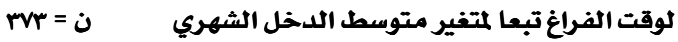

\begin{tabular}{|c|c|c|c|c|c|c|}
\hline الدلالة & قيمة ( ف) & درجات الحرية & متوسط المربعات & مجموع المربعات & الدخل الشهري & مقت الفراغ \\
\hline \multirow{3}{*}{0.01 داJ } & \multirow{2}{*}{45.322} & 2 & 14502.316 & 29004.632 & دنيا & \multirow{3}{*}{ التخطيط } \\
\hline & & 370 & 319.985 & 118394.478 & متوسطة & \\
\hline & & 372 & & 147399.110 & عليا & \\
\hline الدلالة & قيمة (ف) & درجات الحرية & متوسط المربعات & مجموع المربعات & المهنة & \multirow{4}{*}{ التنفيذ } \\
\hline \multirow[t]{3}{*}{0.01 داJ } & 52.496 & 2 & 9357.890 & 18715.781 & دنيا & \\
\hline & & 370 & 178.260 & 65956.192 & متوسطة & \\
\hline & & 372 & & 84671.973 & المجموع & \\
\hline الدلالة & قيمة ( ف) & درجات الحرية & متوسط المربعات & مجموع المربعات & الدخل الشهري & \multirow{4}{*}{ التقييي } \\
\hline \multirow[t]{3}{*}{0.01 داJ } & 45.315 & 2 & 12065.841 & 24131.683 & بين المجموعات & \\
\hline & & 370 & 266.265 & 98518.216 & داخل المجموعات & \\
\hline & & 372 & & 122649.899 & المجموع & \\
\hline
\end{tabular}

يتضح من جدول (1) أن هناك فروق ذات دلالـة إحصائية عند مستوي دلالـة (1... ) هِّ إدارة

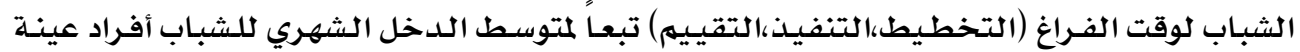

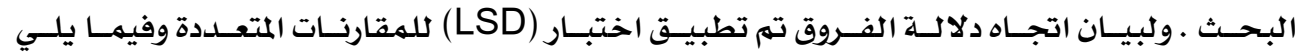




\begin{tabular}{|c|c|c|c|c|}
\hline دخل الشهري & ا لمتغير متوسم & ثباب لوقت الفر & الفروق بين إدار & جدول (ri) \\
\hline 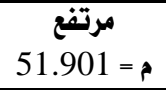 & 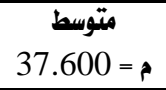 & 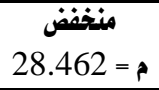 & الدخل الشهري & مقت الفراغ إدارة \\
\hline & & - & دنيا & \multirow{3}{*}{ التخطيط } \\
\hline & - & $* * 9.137$ & متوسطة & \\
\hline- & $* * 14.301$ & $* * 23.439$ & عليا & \\
\hline \multirow{4}{*}{ م = مرتفع } & متوسط & منخفض & المهنة & \multirow{5}{*}{ التنفيذ } \\
\hline & م $36.173=$ & م = 24.754 & & \\
\hline & & - & دنيا & \\
\hline & - & $* * 11.419$ & متوسطة & \\
\hline - & $* * 7.977$ & **19.396 & مرتفع & \\
\hline \multirow{4}{*}{ م = مرتفع } & متوسط & منخفض & 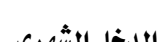 & \multirow{5}{*}{ التقييم } \\
\hline & $37.104=$ & م = & & \\
\hline & & - & منخفض & \\
\hline & - & $* * 11.472$ & متوسط & \\
\hline - & $* * 10.816$ & $* * 22.288$ & مرتفع & \\
\hline
\end{tabular}

يتبين مـن جـدول (r ) وجـود فروق ذات دلالتة إحصائية يْ اتجـاه مستويات الدخول المرتفعـة

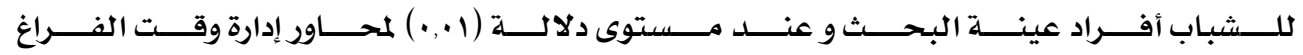

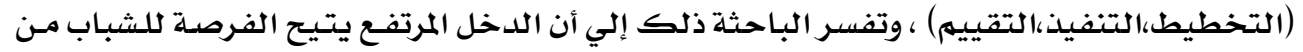

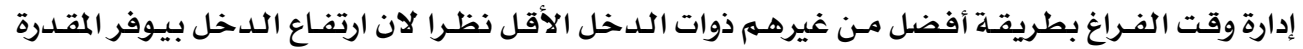

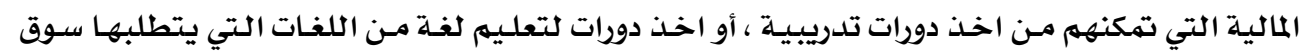

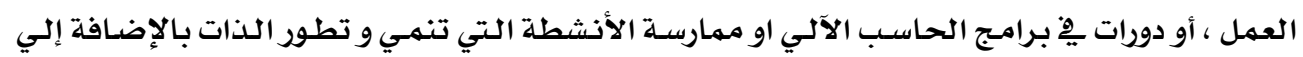

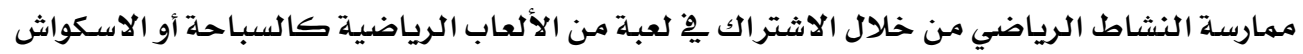

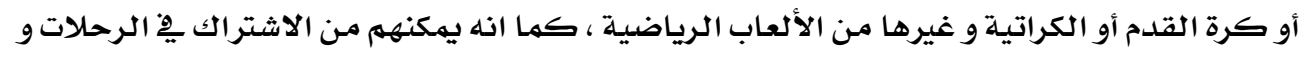

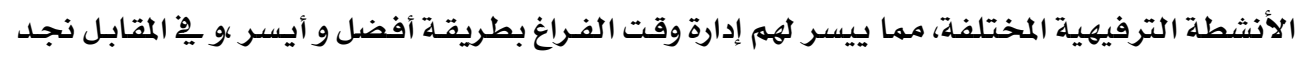

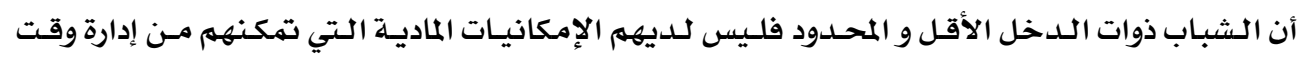

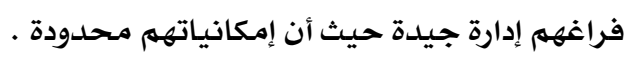

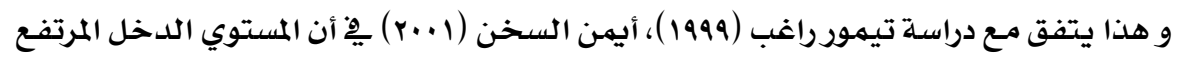

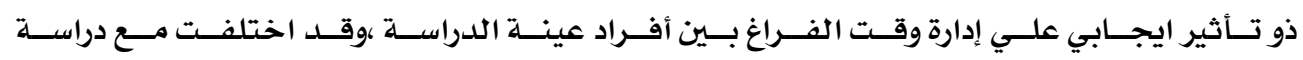
(Yoshioka,1981) 
توجـد فروق ذات دلالـة إحصائية بـين الشباب أفراد عينـة البحـث فِ الرضـا عـن الحيـاة تبعـا

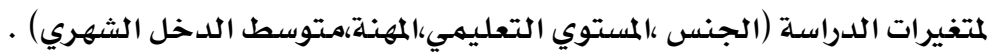

\section{وللتحقق من هذا الفرض تم إجراء:}

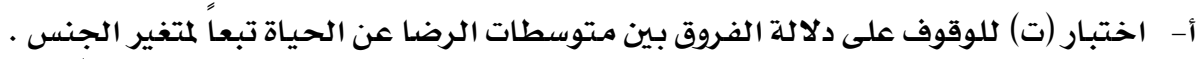

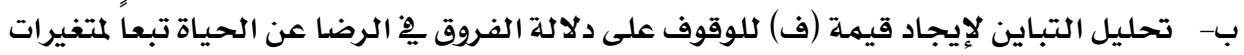

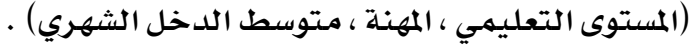

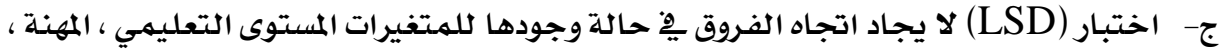
متوسط الدخل الشهري الادئ

جدول (rا ) دلالة الفروق بين متوسطات الرضا عن الحياة

بين الشباب أفراد عينة البحث تبعاً لمتفير الجنس

\begin{tabular}{|c|c|c|c|c|c|c|}
\hline الدلالة & قيمة (ت) & درجات الحرية & العينة & الانحراف المعياري & المتوسط الحسابي & الجنس \\
\hline \multirow{2}{*}{0.271 غير دال } & \multirow{2}{*}{0.975} & \multirow{2}{*}{371} & 149 & 21.814 & 88.261 & ذكر \\
\hline & & & 224 & 27.895 & 87.245 & أثثي \\
\hline
\end{tabular}

يتضح من جدول (rا ) عدم وجود فروق ذات دلالة إحصائية بين متوسطات الرضا عن الحياة

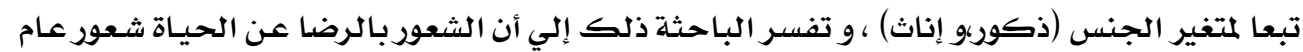

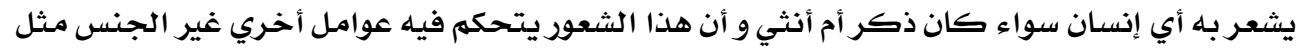

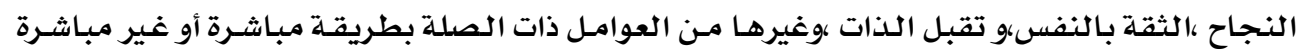

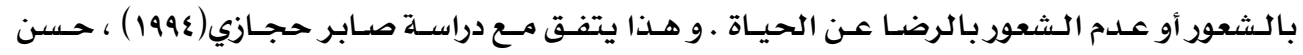

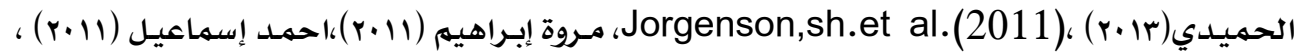

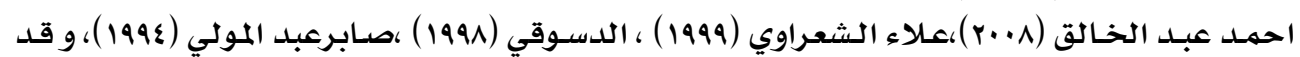

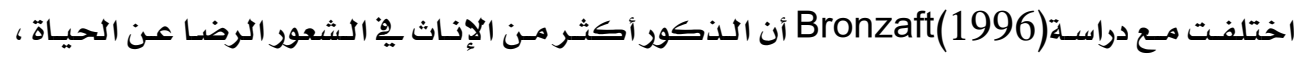

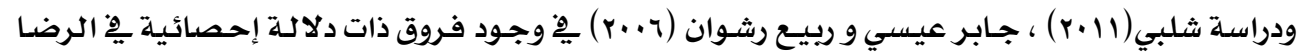

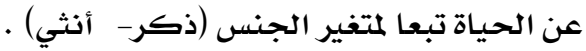


مجلة بحوث التريية النوعية - علد مب - يوليو \&l Pr

جدول (ع ) تحليل التباين للفروق بين متوسطات الرضا عن الحياة بين الشباب أفراد عينة البحث

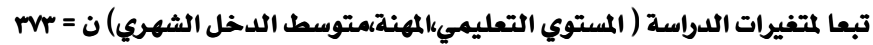

\begin{tabular}{|c|c|c|c|c|c|}
\hline الدلالة & قيمة (ف) & درجات الحرية & متوسط المربعات & مجموع المربعات & المستوي التعليمي \\
\hline \multirow{3}{*}{0.01 داJ } & \multirow{2}{*}{54.582} & 2 & 66298.629 & 132597.258 & بين المجموعات \\
\hline & & 370 & 1214.653 & 449421.509 & داخل المجموعات \\
\hline & & 372 & & 582018.767 & المجموع \\
\hline الدلالة & قيمة (ف) & درجات الحرية & متوسط المربعات & مجموع المربعات & المهنة \\
\hline \multirow[t]{3}{*}{0.01 داJ } & 37.784 & 2 & 33971.009 & 67942.018 & بين المجموعات \\
\hline & & 370 & 899.078 & 332659.017 & داخل المجموعات \\
\hline & & 372 & & 400601.035 & المجموع \\
\hline الدلالة & قيمة (ف) & درجات الحرية & متوسط المربعات & مجموع المربعات & اللدخل الشهري \\
\hline \multirow[t]{3}{*}{0.0101 دال } & 56.704 & 2 & 71326.195 & 142652.391 & بيز المجموعات \\
\hline & & 370 & 1257.858 & 465407.636 & داخل المجموعات \\
\hline & & 372 & & 608060.027 & المجموع \\
\hline
\end{tabular}

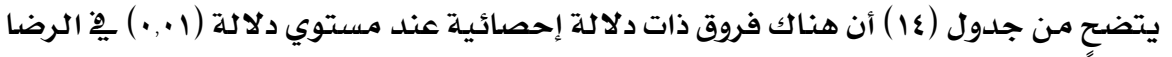

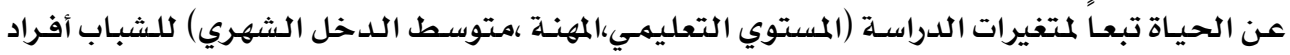

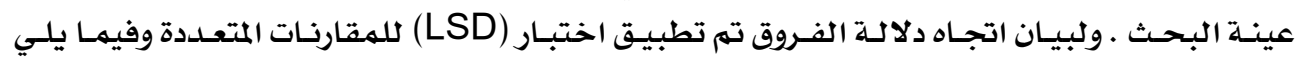
بيان ذلك.

جدول (10) دلالة الفروق يـ الرضا عن الحياة بين الشباب أفراد عينة البحث تبعا لمتغيرات

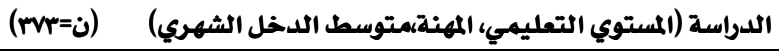

\begin{tabular}{|c|c|c|c|}
\hline $\begin{array}{c}\text { م = عالي } \\
111.850\end{array}$ & $\begin{array}{c}\text { متوسط = م9.139 } 79 . \\
\end{array}$ & 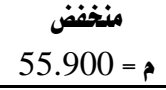 & المستوي التعليمي \\
\hline & & - & منخفض \\
\hline & - & $* * 23.239$ & متوسط \\
\hline- & $* * 32.711$ & $* * 55.950$ & عالي \\
\hline \multirow[t]{3}{*}{$\begin{array}{c}\text { م = ع }=487.987 \\
97\end{array}$} & مت = منوسطة & م = $=2.255$ دنيا & المهنة \\
\hline & & - & دنيا \\
\hline & - & $* * 32.736$ & متوسطة \\
\hline- & $* 2.995$ & $* * 35.732$ & عليا \\
\hline \multirow[t]{3}{*}{ م = مرتفع 112.967} & م = منوسط 80.539 م & م = منخفض & الدخل الشهري \\
\hline & & - & منخفض \\
\hline & - & $* * 21.473$ & متوسط \\
\hline- & $* * 32.427$ & $* * 53.901$ & مرتفع \\
\hline
\end{tabular}




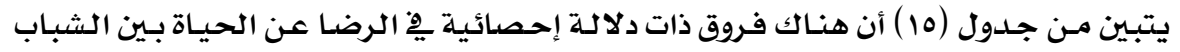

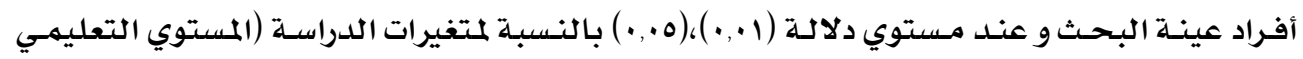

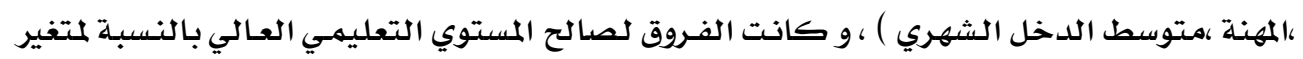

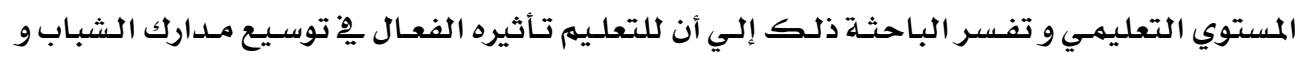

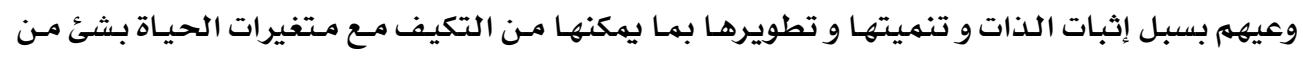

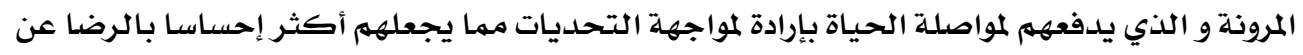

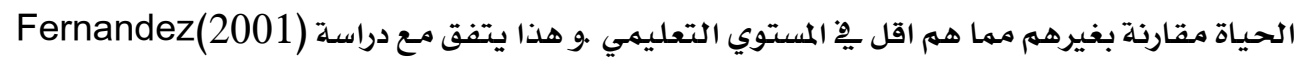

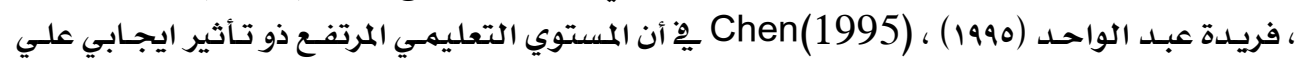

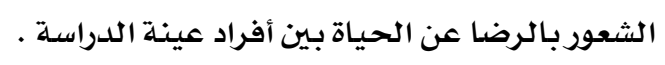

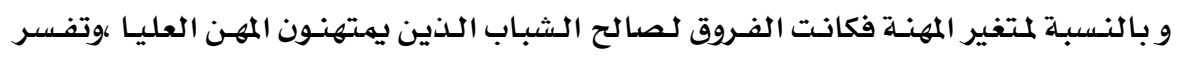

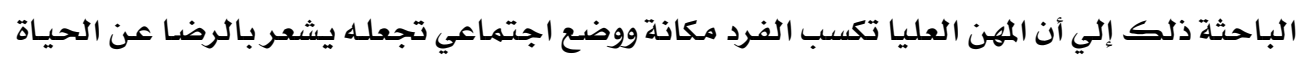

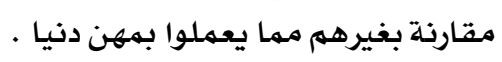

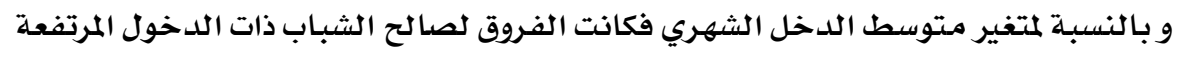

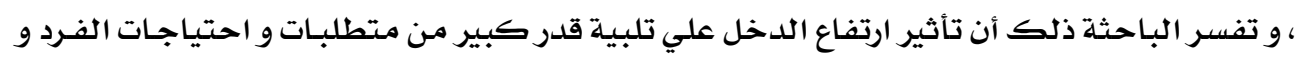

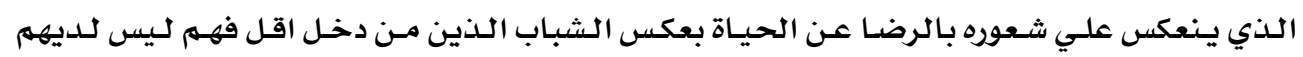

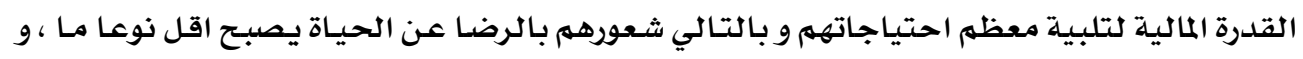

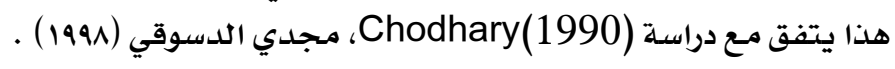
الفرض الثالث:

توجد علاقة ارتباطيه ذات دلالة إحصائية بين إدارة الشباب لوقت الفراغ بمحاوره وبين الرضا عن الحياة بأبعاده . وللتحقق من هذا الفرض تم حساب معامل ارتباط بيرسون لإيجاد العلاقة بـين مقياس إدارة

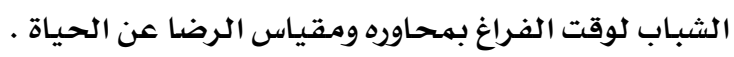

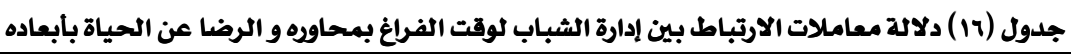

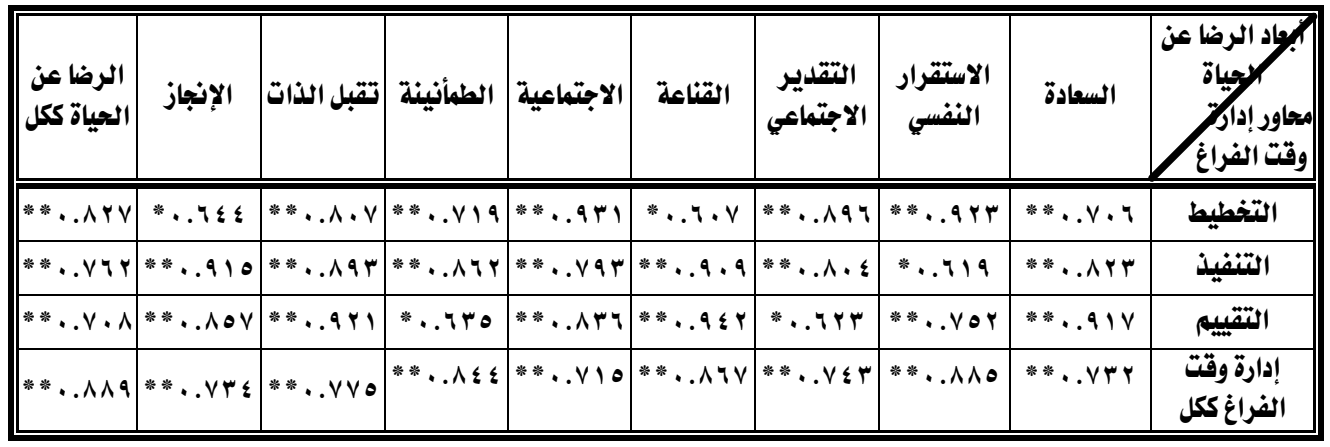




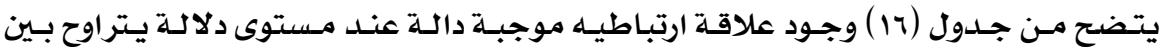

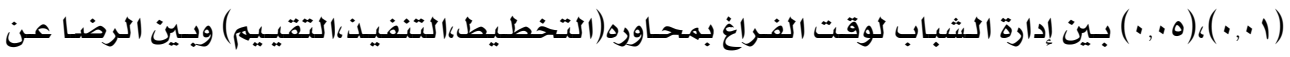

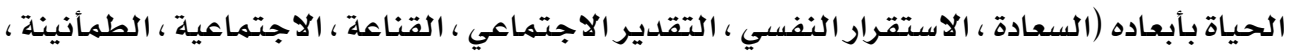

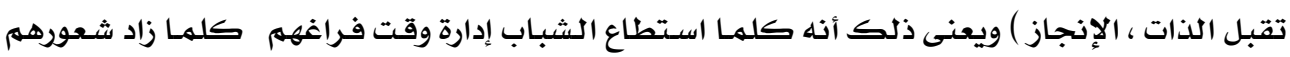

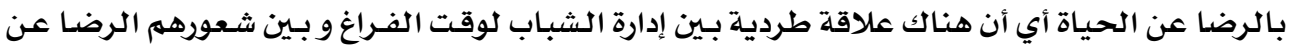

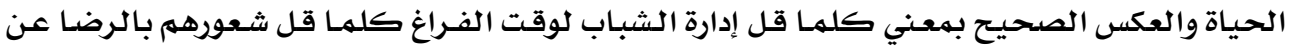

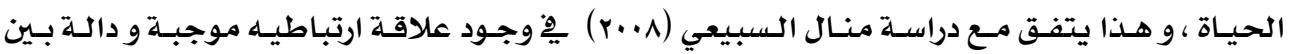

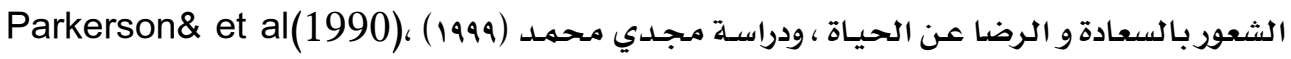

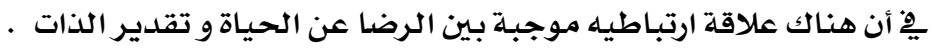

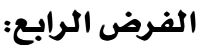

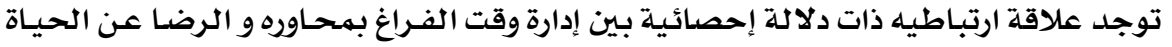

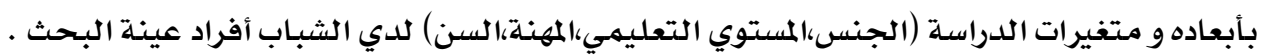
وللتحقق من هذا الفرض تم حساب مصفوفة معاملات الارتباط بيرسون لإيجاد العلاقة بين

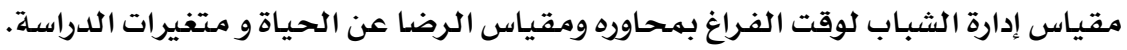

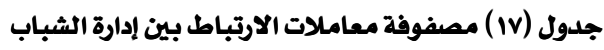

لوقت الفراغ بمحاوره و الرضا عن الحياة بأبعاده و متغيرات الدراسة

\begin{tabular}{|c|c|c|c|c|c|c|c|c|c|c|c|c|c|}
\hline |الحياة ككل & الإنجاز & الذات & |الطمأنينة & الاجتماعية & القناعة & الاجتماعير التقدير & الاستقرار & السعادة & إإدارة وقت & التقيييم & التنفيذ & التخطيط & |المتفيرات| \\
\hline. $.1 V \varepsilon$ & $.1 \leq r$ & . Yr & .1 .0 & $.1 r v$ & .ril & .101 & .199 &. $.11 r$ & זי & .r.r & rוג &. $.1 r v$ & الجنس \\
\hline r & 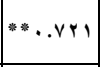 & $* * a, \ldots$ & * * . vor & $* 71 \leq$ & $* * . \wedge 9 \vee$ & $* * \vee \vee \vee \neg 1$ & $* *$ * . Ar & $* * . \wedge \wedge \neg$ & $* * . \wedge \circ \%$ & W** & $* .7 .1$ & *** $\bullet \vee \vee \wedge \varepsilon$ & التمليمي \\
\hline$* * . \wedge \vee r$ & $* * .911$ & $* x \leq r$ & **..V^r & $* * . \wedge 1 \mathrm{r}$ & $* . . v 1 r$ & * *.9 & * . . & $* * . V . \varepsilon$ & $* * . \vee v 1 \wedge$ & $* .711$ & $* * . \vee \vee 90$ & $* * a \cdot r$ & المهنة \\
\hline$* * v \leq v$ & $* * \cdot V \cdot v$ & $* * . \wedge r q$ & * * . & $* * . \wedge \vee 0$ & *. . . & $* * . V \leq 7$ & $* * . \wedge \circ 9$ & $* * .91 \mathrm{r}$ & $* * . \wedge 1 \leqslant$ & *** . . V 0 \& & 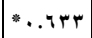 & $* * . \wedge 17$ & السن \\
\hline ***.. $\vee \vee \wedge$ & *. * V V & $* *, . \Lambda \leq V$ & $* .7 .9$ & $* *$ *.VVI & $* * .1 .9$ & **..人 & $* * \vee \vee \vee \vee \wedge$ & $* * . \vee V V V$ & $* * . V Y \varepsilon \varepsilon$ & $* * . \wedge \vee 7$ & $* * * \Lambda \leq \Lambda$ & 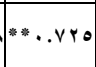 & الشهري اللخل \\
\hline
\end{tabular}
بدون نجوم غير دال

0.05 * دال عند

0.01 * \$ دال عند

يتضـح من جدول (IV) وجود علاقة ارتباطية موجبـة بـين إدارة الشباب لوقت الفـراغ بمحساوره

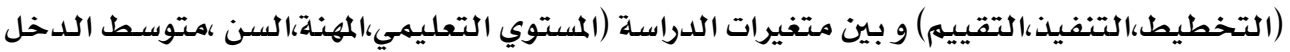

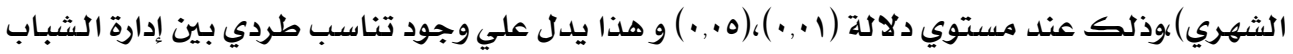

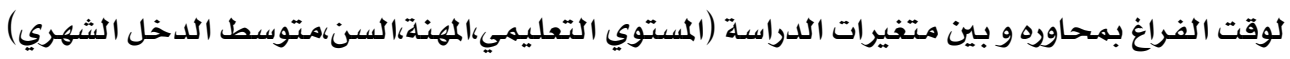

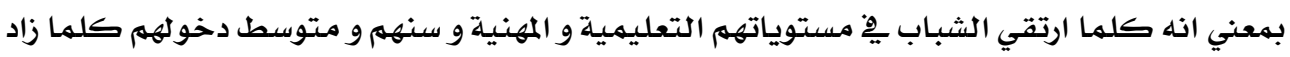

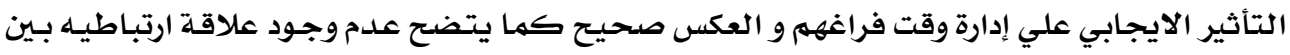

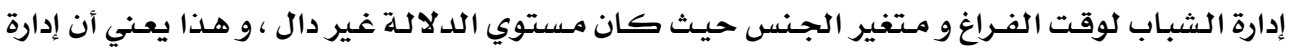

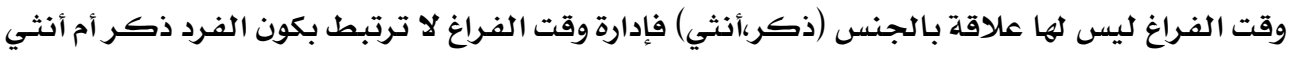




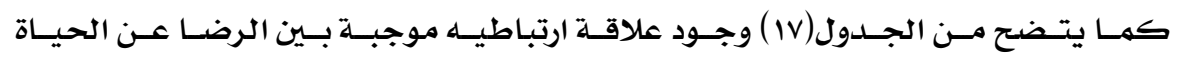

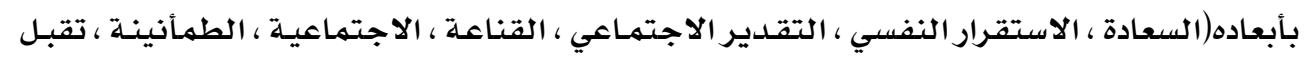

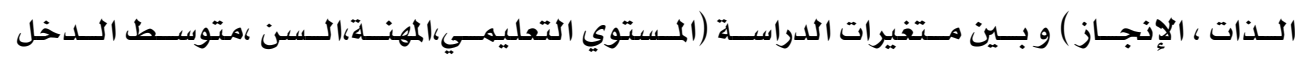

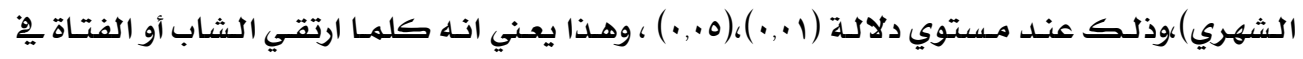

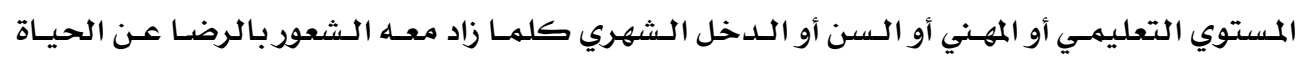

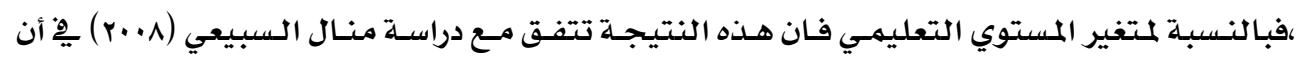

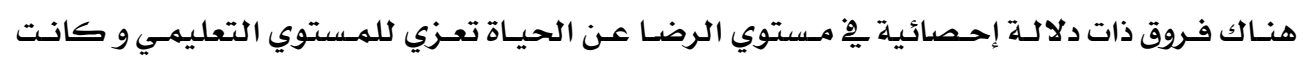

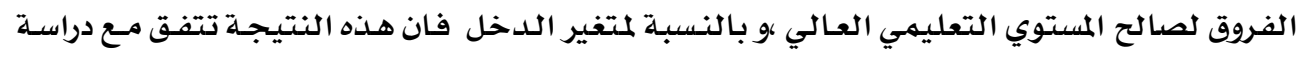

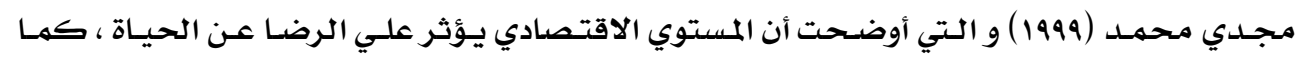

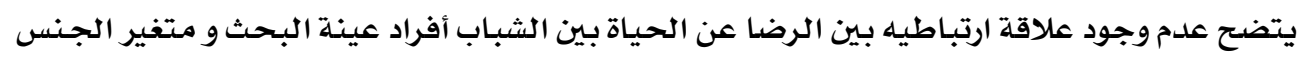

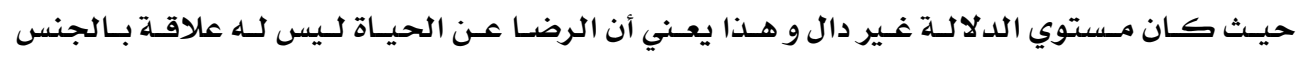

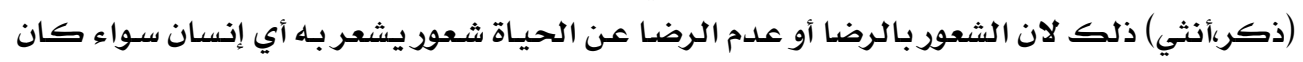

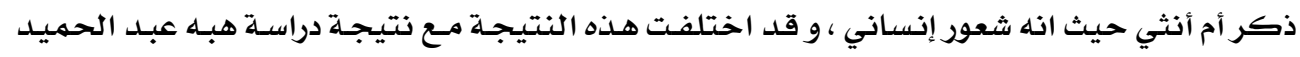

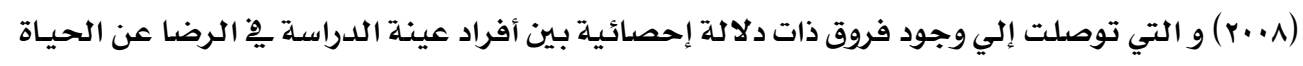

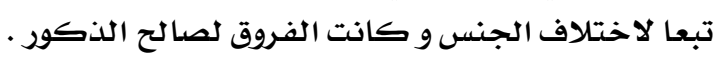
الفرض الخامس:

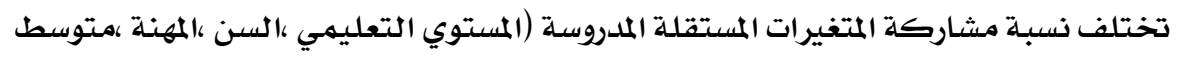

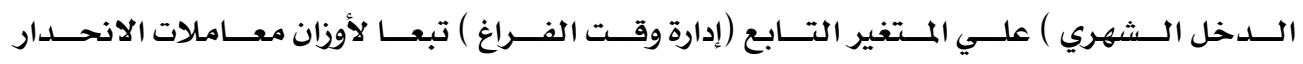
و درجة الارتباط.

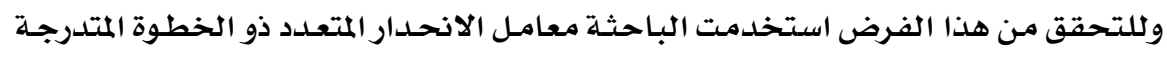

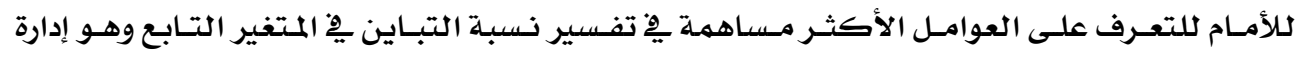

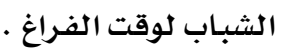

جدول (11) معاملات الانحدار باستخدام الخطوة المتدرجة للأمام

\begin{tabular}{|c|c|c|c|c|c|c|c|c|}
\hline الدلالة & قيمة (ت) & الانحلا & الدلالة & قيمة ف) & الششبة & الارتباط معامل & المتفير المستقل & $\frac{r}{t} x$ \\
\hline 0.01 & 8.644 & 0.448 & 0.01 & 74.719 & 0.727 & 0.853 & المستوي التعليمي & $\overline{\mathbf{E}_{0}}:$ \\
\hline 0.01 & 7.419 & 0.366 & 0.01 & 55.041 & 0.663 & 0.814 & السن & $\stackrel{E}{*}$ \\
\hline 0.01 & 6.355 & 0.282 & 0.01 & 40.386 & 0.591 & 0.768 & المهنة & \\
\hline 0.01 & 5.552 & 0.211 & 0.01 & 30.831 & 0.523 & 0.724 & اللدخل الشهري & \\
\hline
\end{tabular}

يتضح من جدول ( M 1 ) أن كلا من (المستوي التعليمي-السن - المهنة - الدخل الشهري)

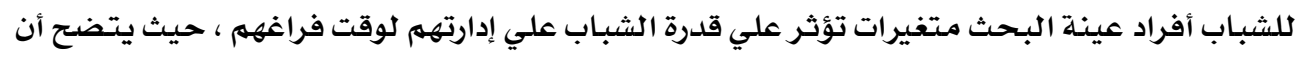

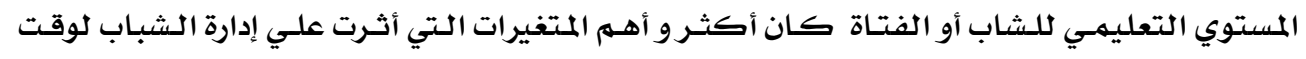


الفراغ حيث بلغت نسبة المشاركة (VYV, • ) بمستوي دلالـة (1., •) ) ويليـه مستغير السن بنسبة مشاركة

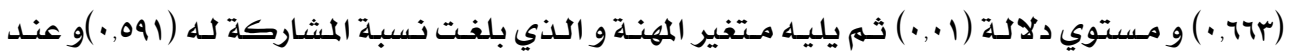

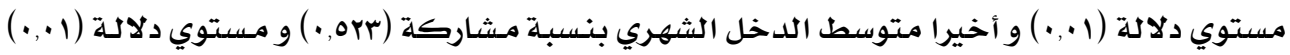

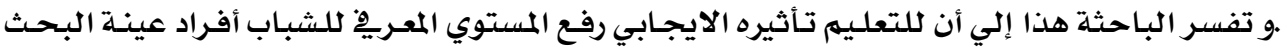

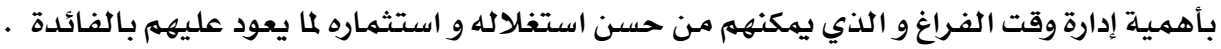
الفرض السادس:

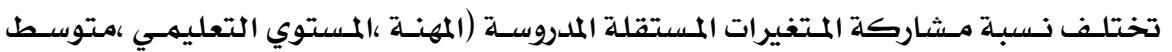

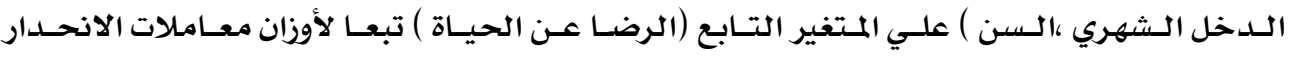

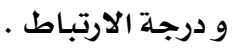

وللتحقق من هذا الفـرض استخلدمت الباحثة معامل الانحسدار المتعـدد ذو الخطوة المتدرجـة

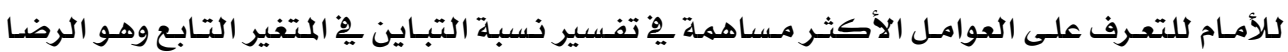
عن الحياة . لامامليعر.

جدول (19) معاملات الانحدار باستخدام الخطوة المتدرجة للأمام

\begin{tabular}{|c|c|c|c|c|c|c|c|c|}
\hline الدلالة & قيمة (ت) & الانحلار & الدلالة & قيملة ف) & المشاركة & الارتباط & المتفير المستقل & \\
\hline 0.01 & 9.485 & 0.495 & 0.01 & 89.957 & 0.763 & 0.873 & المهنة & \\
\hline 0.01 & 7.973 & 0.405 & 0.01 & 63.574 & 0.694 & 0.833 & المستوي التعليمي & \\
\hline 0.01 & 6.997 & 0.334 & 0.01 & 48.959 & 0.636 & 0.798 & الدخل الشهري & \\
\hline 0.01 & 5.954 & 0.247 & 0.01 & 35.447 & 0.559 & 0.747 & السز & \\
\hline
\end{tabular}

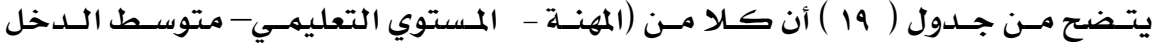

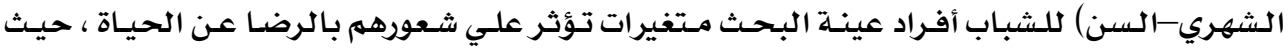

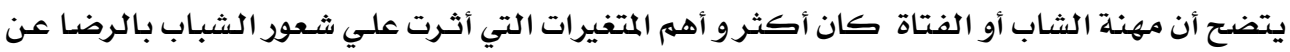

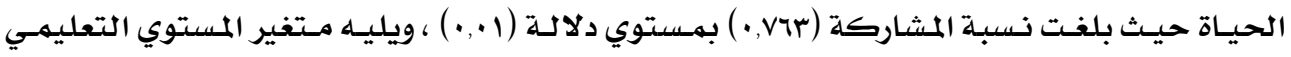

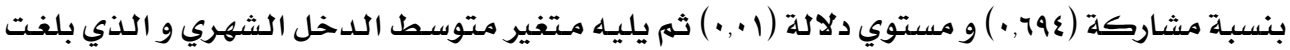

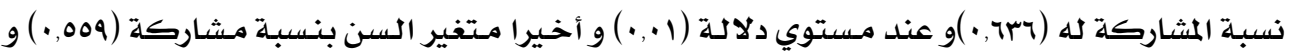

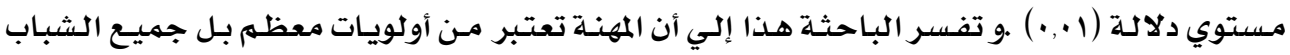

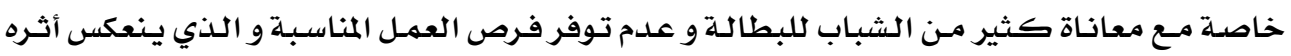

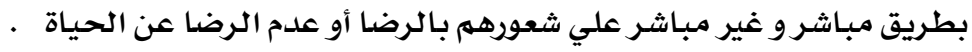

\section{هلخص النتائج:}

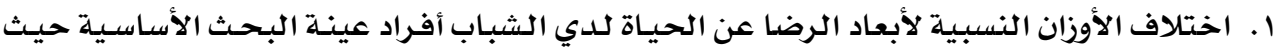

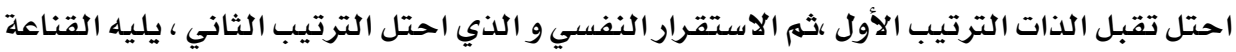

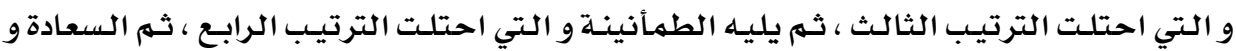




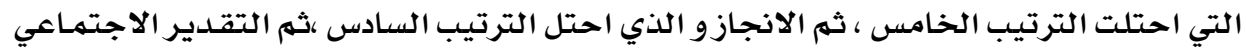

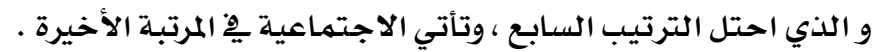

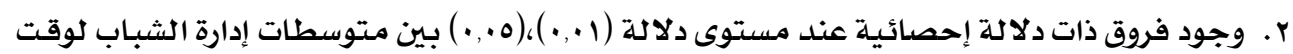

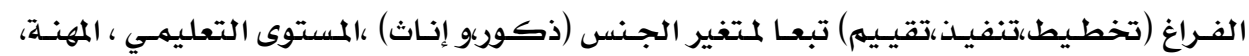

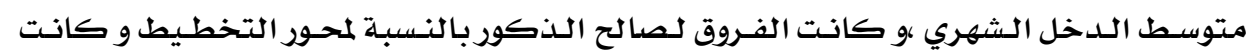

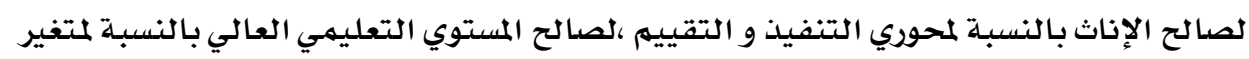

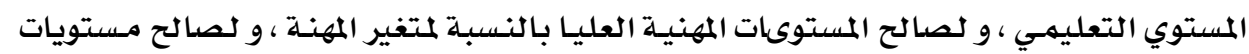

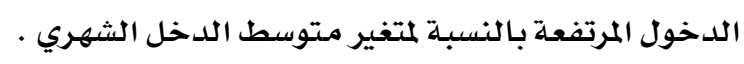

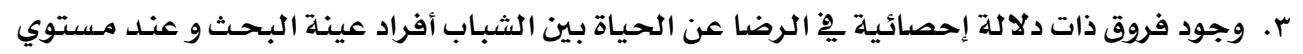

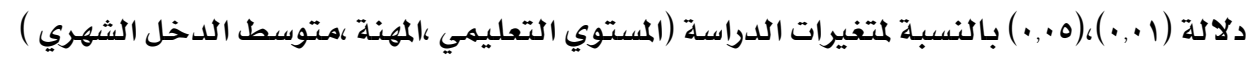

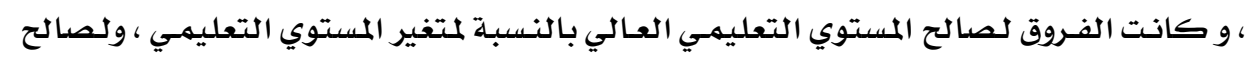

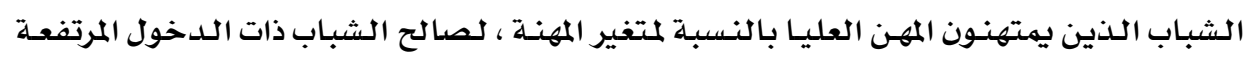

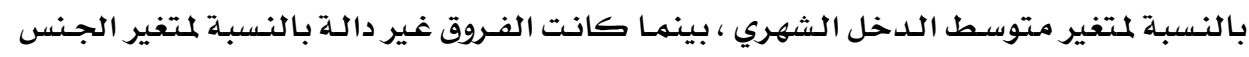

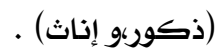

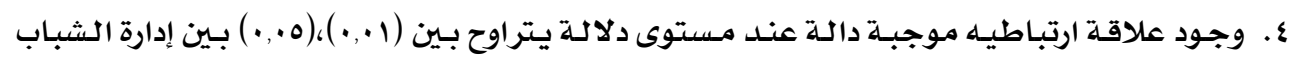

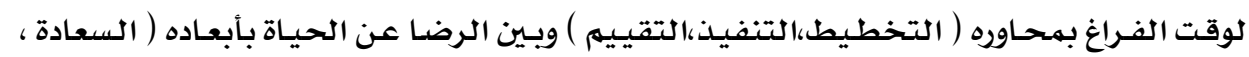

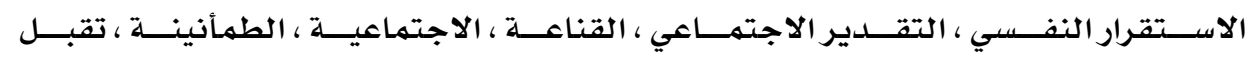

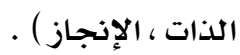

ه. وجود علاقة ارتباطية موجبة بين إدارة الشباب لوقت الفراغ بمحاوره (التخطيط،التنفيذ،التقييم)

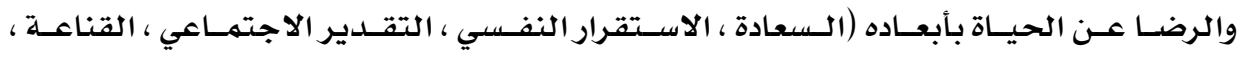

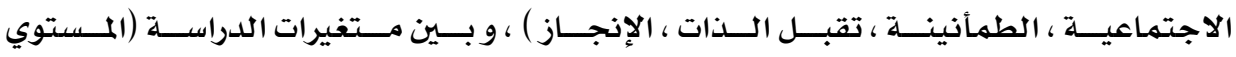

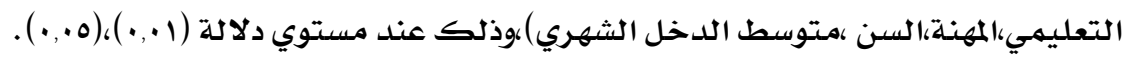

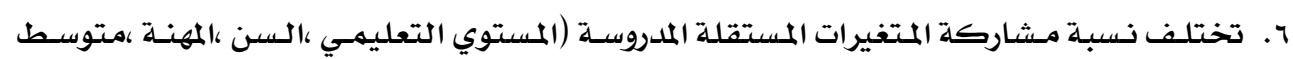

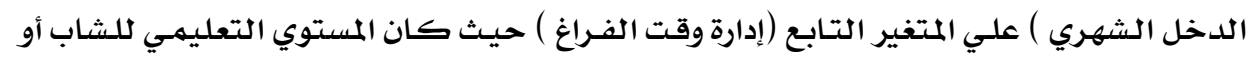

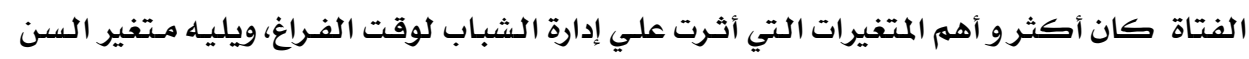

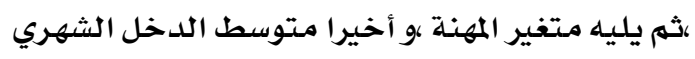

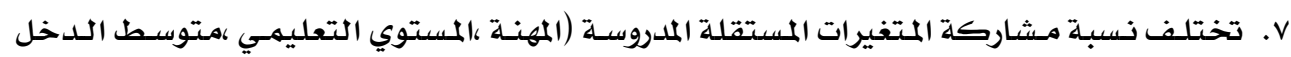

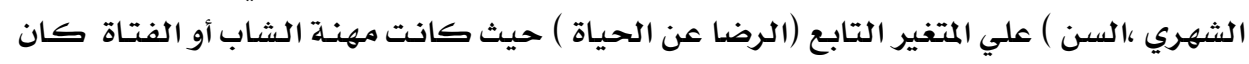

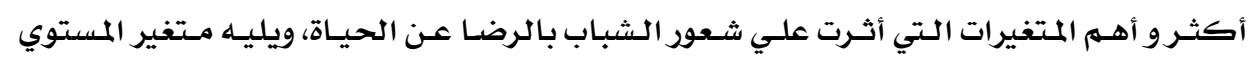

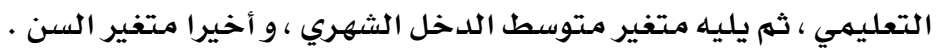




\section{توصيات البحث: \\ توصي الباحثة بما يلي :}

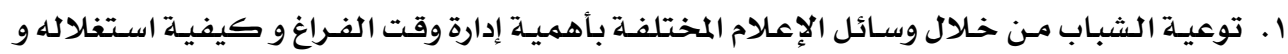

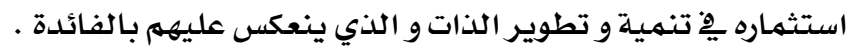
r. إعداد مقرر دراسي عن كيفية إدارة وقت الفراغ بجميع المراحل الدراسية حتى يزداد الوعي بكيفية

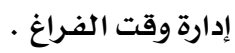

r. تبني قسهم إدارة مؤسسـات الأسـرة و الطفولة إقامـة و إعداد دورات تدريبيـة و ندوات تثقيفيـة لتوعيـة

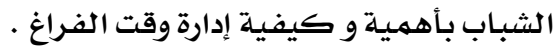

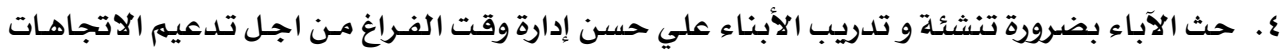

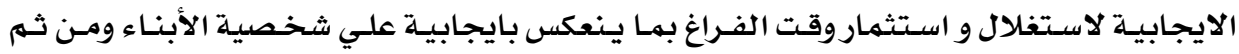

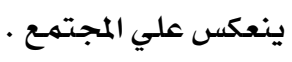

ه. تدعيم الجانب الديني ِِّ نفوس الشباب لما له من تأثير ايجابي علي شعورهم بالرضـا عن الحياة .

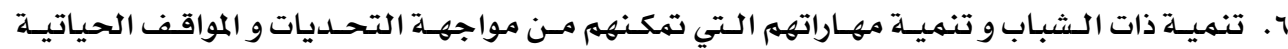

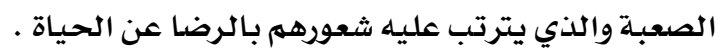

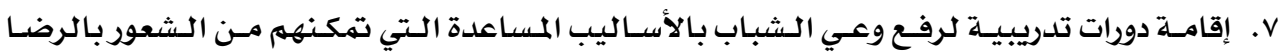
عن الحياة .

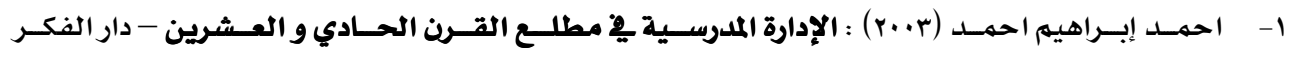

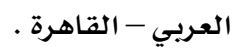

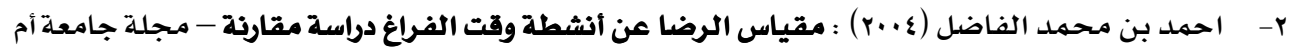

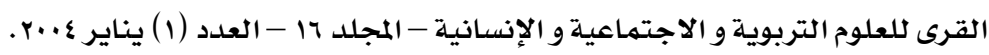

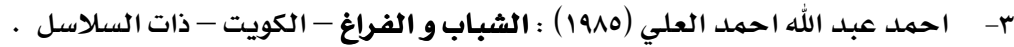

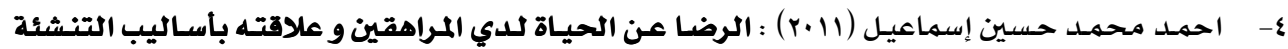

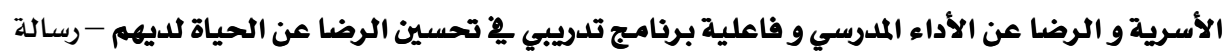

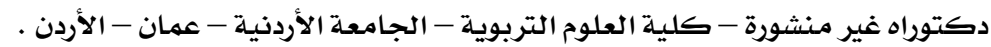

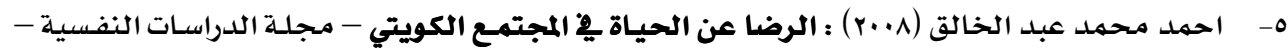

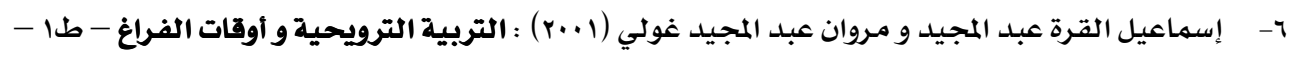
مؤسسة الوراق للنشر و التوزيـع - الأردن . 


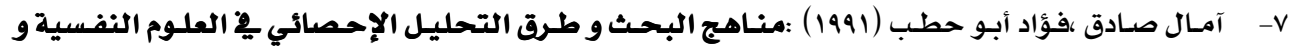

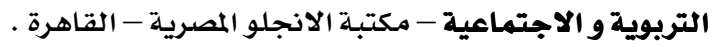

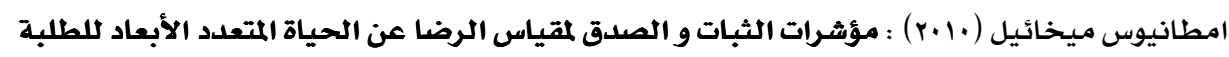

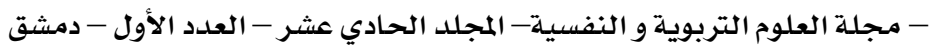

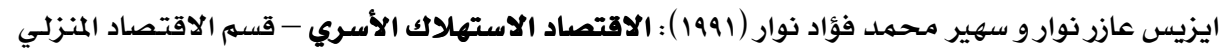

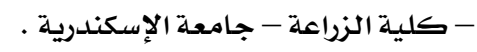

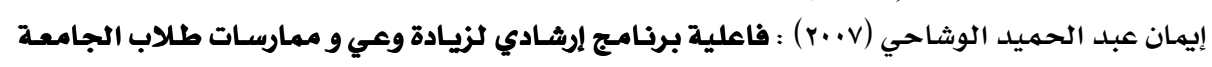

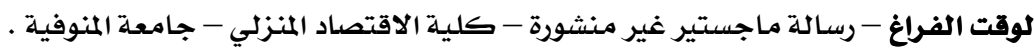

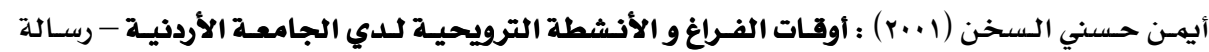

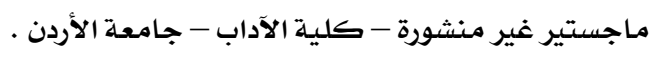

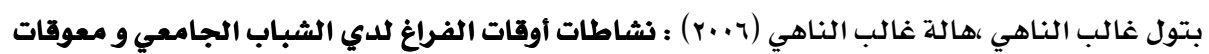

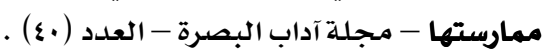

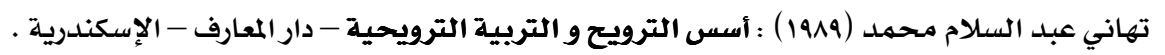

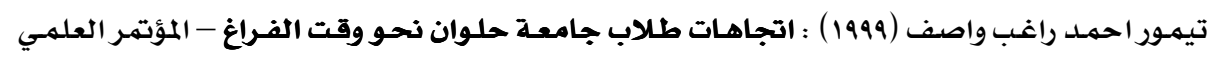

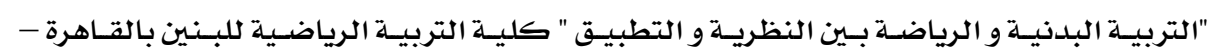

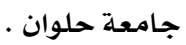

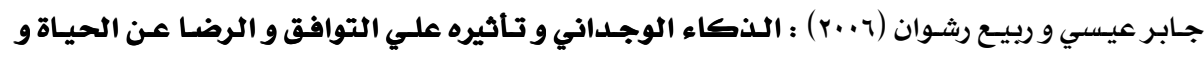

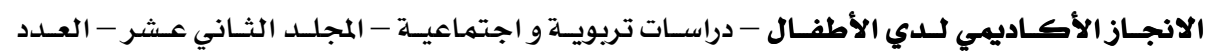

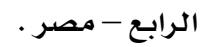

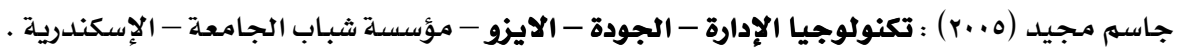

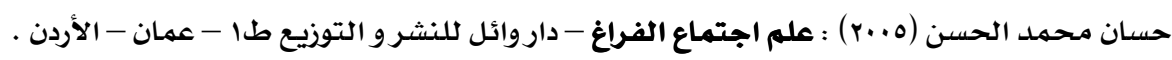

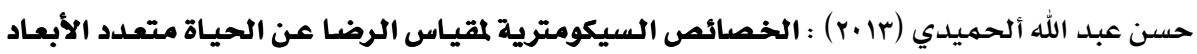

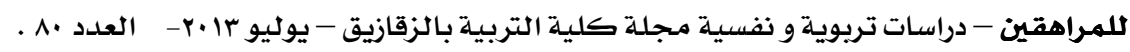

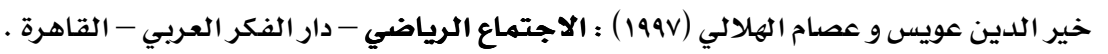

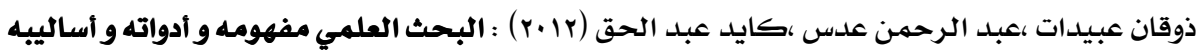

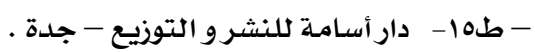

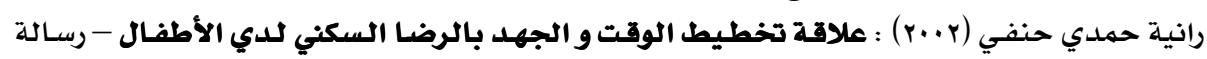

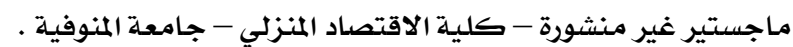

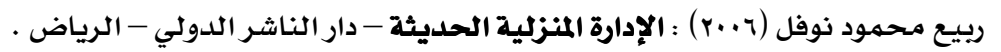

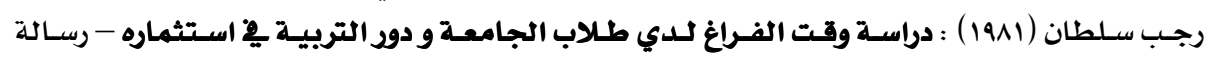

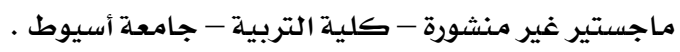

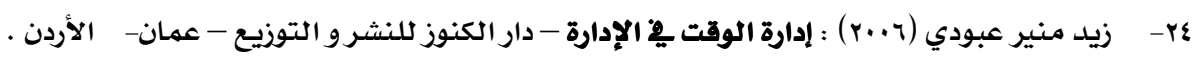

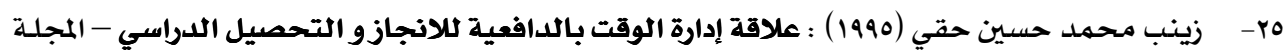

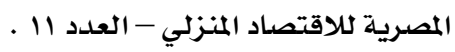


$\underline{\underline{ }}$ مجلة بحوث التربية النوعية - علد مr - يوليو 18

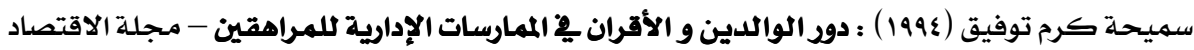
المنزلي - العدد العاشر - الجمعية المصرية لكلاقتصاد المنزلي - القاهرة .

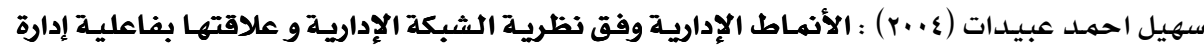
الوقت - طا - عالم الكتب - الأردن .

سهيل فهد سلامـة (19M1) : إدارة الوقت منهج متطود للنجاح ، المنظمة العربية للعلوم الإداريـة (سلسلـة

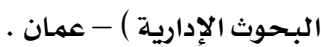

سوسن إبراهيم شلبي (11 +r) : أساليب التعلق و العوامل الخمس ألكبري للشخصية و علاقتها باكرضا عن الحياة لدي طلاب الجامعة - مجلة الإعلام التربوي و العلوم الإنسانية - مصر .

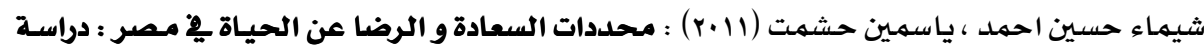
تطبيقية باستخدام مسبح القيم العالمية ، مجلس الوزراء المصري ، مركز المعلومات و دعم اتخاذ القرار. صابر حجازي عبد المولي (ع991) : دراسة للرضا عن الحياة و بعض المتغيرات النفسية و البينية - مجلة البحوث النفسية و التربوية - كلية التربية - جامعة المنوفية - يناير .

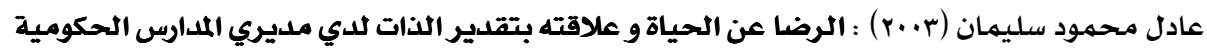
و مديراتها يو مديرات محافظات فلسطين الشمالية - رسالة ماجستير غير منشورة - جامعسة النجـاح

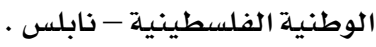
عبد الحكم احمد الخزامي (1999) : إدارة الوقت = إدارة الحياة - مكتبـة ابن سينا - القاهرة .

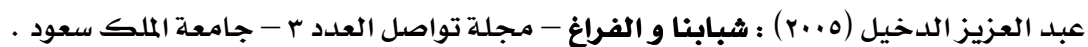

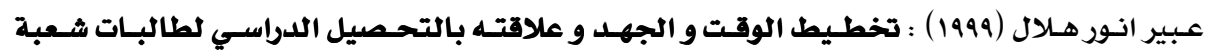
الاقتصاد المنزلي - رسالة ماجستير غير منشورة - كلية التربية النوعية - جامعة المنوفية .

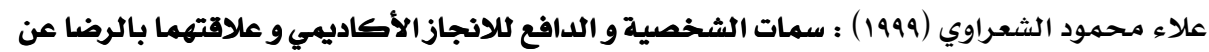

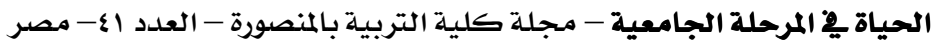

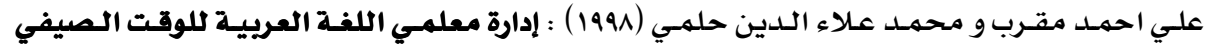

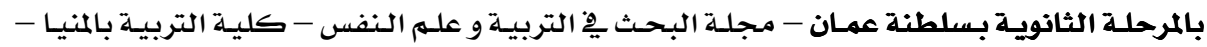

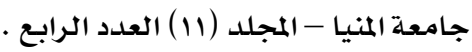

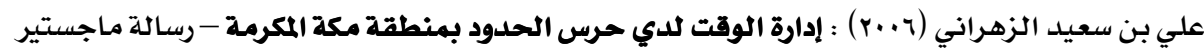

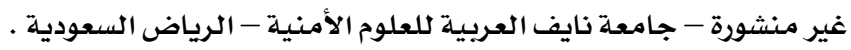

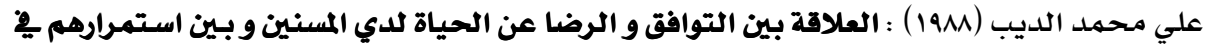

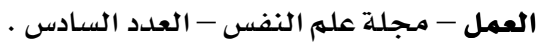

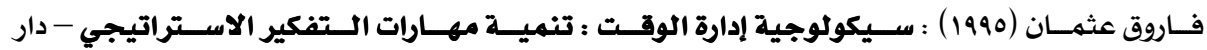
المعارف - القاهرة .

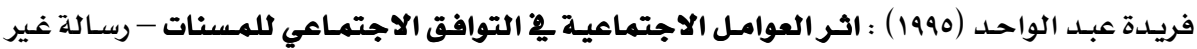

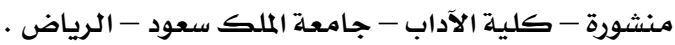
فوقية محمد راضي (r +.r) : مهارات إدارة الوقت لدي طلاب الجامعة و علاقتها بالتحصيل الدراسي و $-\varepsilon Y$ القدرة علي التفكير ألابتكاري و الضغوط النفسية - مجلة كلية التربية بـالمنصورة - جامعة المنصورة 


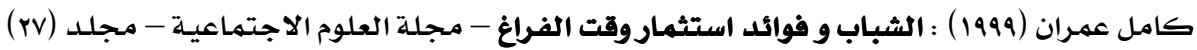
- العدد (r) . كمال إبراهيم مرسي (.... ( ) : السعادة و تنمية الصحة النفسية - الجزء الأول - دار النشر للجامعات

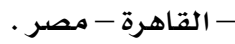

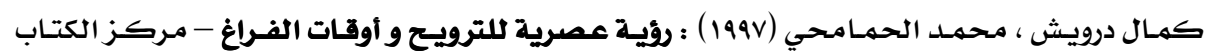
للنشر - القاهرة . كمـال درويش ، محمـد محمـد الحمـاحمي (199V) ) : رؤيـة عصرية للترويـح و أوفـات الفـراغ - مركـز

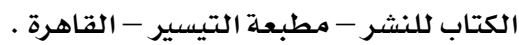

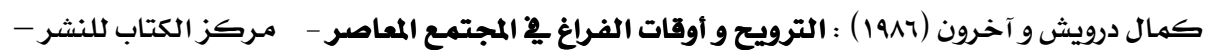
طץ- القاهرة . كوثر حسين كوجك (1994) ) : الإدارة المنزلية - عالم الكتب - طه- القاهرة

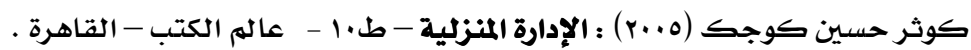

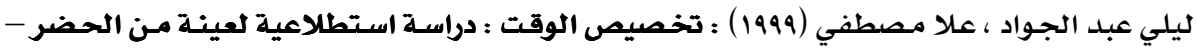

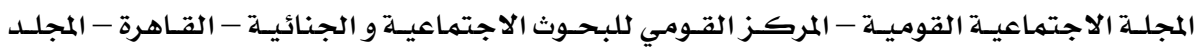

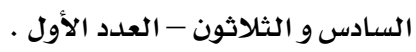

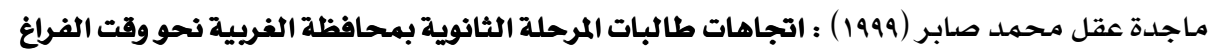

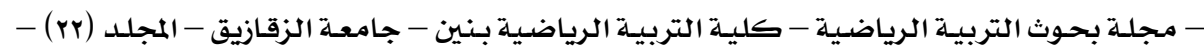

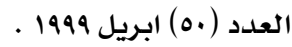

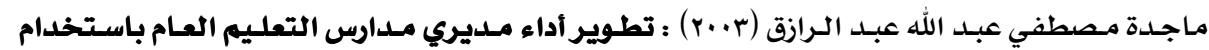

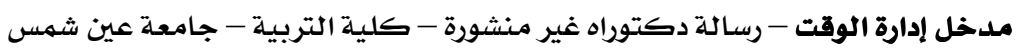

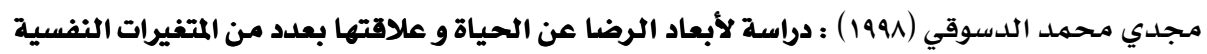

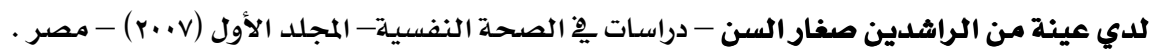

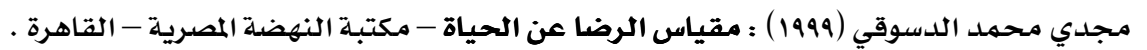

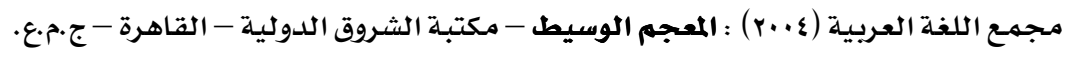

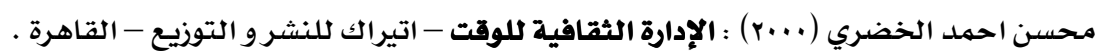

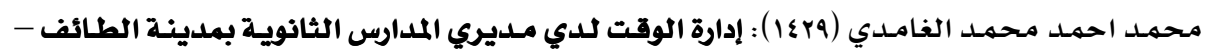

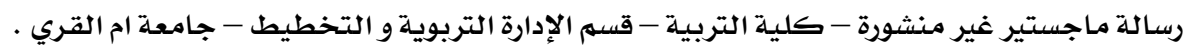

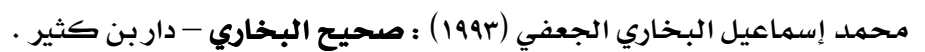

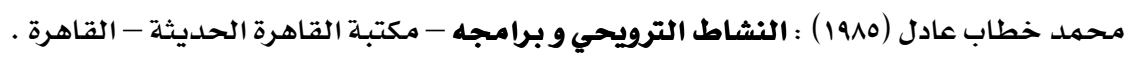

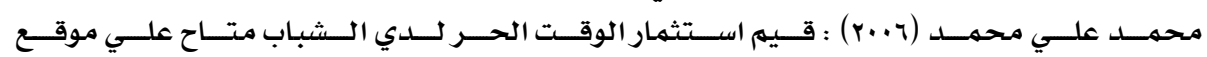
.http://Www.balagh.com

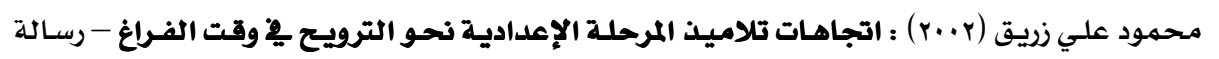
$-71$

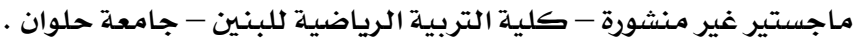




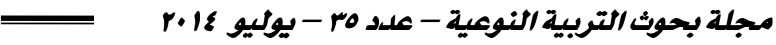

rا- م-روة محمد إبراهيم (11 +r) : الرضا عن الحياة و علاقته ببعض المتغيرات النفسية لدي طلاب الجامعسة

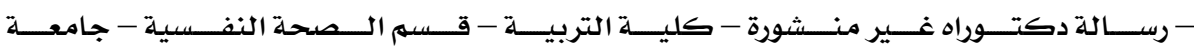
حلوان - جم:ع.ع.

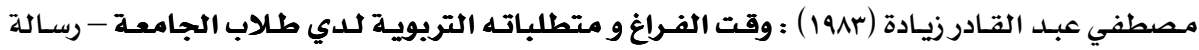
دكتوراه غير منشورة - كلية التربية - جامعة عين شمس .

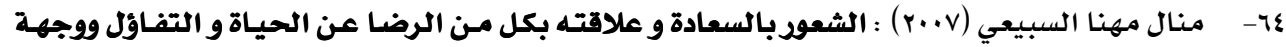
الضبط للدي المتزوجات ــ ضوء بعض المتغيرات الديموجرافية - رسالة ماجستير غير منشورة - كلية

العلوم الاجتماعية - قسه علهم النفس - جامعة الإمام محمد بن سعود - المملكة العربية السعودية . 10- منظمـة الصحة العالميـة (1990) : تعزيـز الصححة النفسية - المفـاهيم البيانـات المستجدة - الممارسـة -

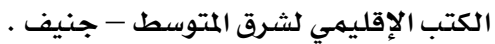

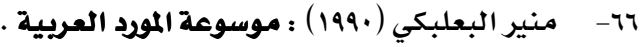

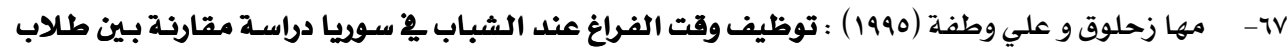

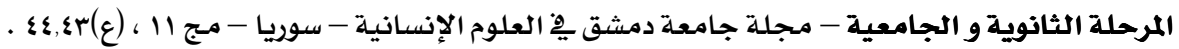

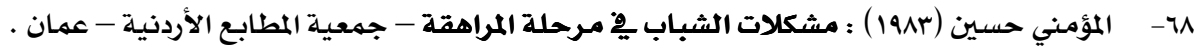

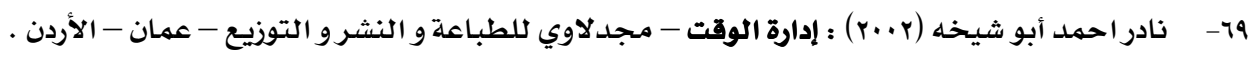

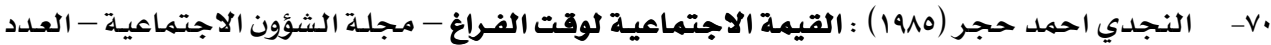

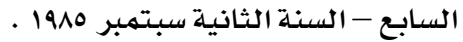

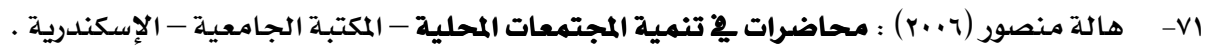

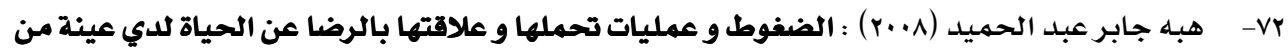
معـاوني أعضاء هيئهة التـدريس بالجامعـة - رسـالة ماجستير غير منسشورة - كليـة التربيـة - جامعسة

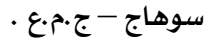

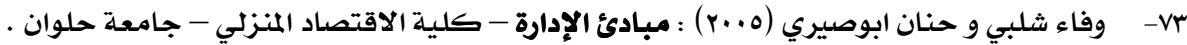

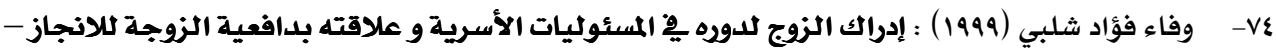

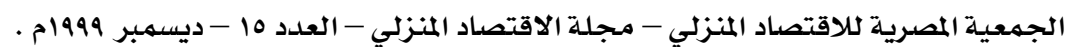

ثانيا : المراجع الأجنبية :

75-Anderssen N ,. Oygard L (1998) : Social influences and leisure - time physical activity levels in young people $\mathbf{A}$ twelve - year fllow-up study, journal of Health psychology United kingdom .

76-Anne Passmore and Frensh Davina (2001): Development and Administration of A Measure to Assess Adolescents Participation in Leisure Activities. School occupational There.

77-Bee , R . \&Ronaghy , H (1990) : A time Budget analysis of collegiate major - college student Journal , 24 .

78-Bronazaf Arline. L. (1996): Top of the class: Guiding children along the smartpath to happiness. Creativity Research.

79-Bryant, Judith , A . \& Others (1995) : Assessment Provides insight into the impact effectiveness of Campus Recreation Programs .NASPA Journal, V.3202 . 
80-Canada , B . (2003) : Life Satisfaction and Self Concept of Elderly Living in Congregate and Non-congregate Housing In Knoy County, Tennessee ,Phd Thesis . The University of Tennessee, Knoxville U . S . A .

81-Charies E ., Lance, Lautenschlager, Sioan Gary J ., Christopher E ., \& Varco , Philip E (2006) : a comparison Between Bottom - Up , TOP - Down and Bidirectional Models of Relationships Between Global and Life facet Satisfaction . Journal of Personality . Vol . 57 . Issue 3 , P , 601-624-28 .

82-Chen Ching Huey (1995): physical exercise and sense of well-being among Chinese elderly in Taiwan. PHD. The University of Texas at Austin, Dissertation Abstracts International,56 (108), 5413.

83-Chodhary, U (1990): Notion of Control and self esteem perceptual - and motor skills vol, 70 .

84-Dammer, Beck, anne , M (1995): The Political Economy of The Family A study of Household Time Use Decision University of Missouri - Columbia .

85-Diner , E.\& Ryan , K .(2009) : Subjective Well-being :A general of review . South African Journal of Psychology , 39(4),391-406.

86-Donald et al . (2011) : Relationships of Personality affect, emotional intelligence and coping with student stress and academic success : Different Patterns of association for stress and success origina Research -Available online 14 March : $105-117$.

87-Donald Martin Mccoy\& Jeannette G. Heritage (1992) : Abstract the Relationship of Dominance, Self Esteem, and life Satisfaction to selected Variables . Paper Presented at the annual meeting of the middle Tennessee Psychological association Nashville . April 26/1992.

88-Edward , Lucas , Richard E , and Suh , Eunkook M (1999) : Cross-Wltural Variations in Predictors of life Satisfaction : Perspectives From needs and Values . Journal of Personality and Social Psychology Bulletin . Vol . 25 , No. 8, P.980-990 .

89-Elke Zeijl, and Yolanda To Pole others (2000) : The Role of Parents and Peers in the Leisure Activities of Young Adolescents, Journal of Leisure Research, Third Quarter , Vol. 32 .

90-Fernande Z Ballesteros (2001): The contribution of social demographic and psychological factors to life satisfaction. Journal Ageing and Society, 21.

91-Gilligan T.\&Huebner S.(2002) : Multidimensional Study , Personality and individual differences, $32,1149,1155$.

92-Heo, J\&Lee, Y, (2010) : Serious Leisure , Health Perception, Dispositional Optimism and life Satisfaction among Senior Games Participants Educational Gerontology Vol (36), No(2) pp 112-126.

93-Hodgetts , M . R . and Kuratk F . D . (1991) :Management (3ed) Harcourbrace Jovanovich , Inc .

94-Jenkins, John M . and JJJ Pig ram (2003) : Encyclopedia of Lei .

95-Jorgenson, sh .et al (2011) : College satisfaction and academic success: A comparison by sex and disability official International Research.Dawson College.

96-Kogan , L . (2008) : The Concept of Leisure A Academic Sciences . Moscow , 25 .

97-Lu , L. (1999) : Personal and Environmental Causes of Happiness : A longitudinal Analysis 
مجلة بحوث التربية النوعية - علد مبr - بيوليو

98-Martin, K, Hubber , S. \&Valois, R.(2008): Does life Satisfaction Predict Victimization experiences in Adolescence? Psychology in the schools .,45(8)705-714.

99-Oishi, Shigehiro, Diener ,Edward . Lucas, Richard E , and Suh , Eunkook M , (1999) : Cross-Cultural Variations in Predictors of Life Satisfaction : Perspective from needs and Values . Journal of Personality and Social Psychology Bulletin, Vol . 25 , No. 8,P 980-990 .

100-Parkerson, G.R. Jr. Broad head, W.E, and Tse, C-K.J (1990): The duke health profile, a 17- item measure of health and dysfunction. Medical care Vol. 28 (11): 1056-1072.

101-Richard E . Bail\&Lynn Robbins (1983) : Marital Status and life Satisfaction , of Black Men . Paper Prepared for Presentation at the annual meeting of the national Council on Family relations, St . Paul . Oct 12-15/1983 .

102-The Whoqol Group (1998) : The World health Organization quality of life assessment (WHOQOL) Development and general Psychometric Properties, Social Science and Medicine . 46,12,1569-1585

103-Trueman. M, \&Hartley, J. (1996): A comparison between the time management skills and academic performance of mature and traditional - entry University students. Higher Education 32,2,199-215.

104- Turner, Mo , F ., Kerwski , M . D ., Mo . F . D . (2005) : Physical Inactivity And Socioeconomic Status In Canadian Adolescents . International Journal of Adolescent Medical Health . Jan Mar, Vol (17), No.(1) .pp.(49-56) .

105-Yoshioka Carlton F . (1981) : Leisure socialization and adult and child related decision. Making interactions in family recreational activities; PH.D, University of Oregon.

106-Young, Margaret, H ., Miller , B , Norton, Maria \&Hill, Jeffery (1995) : The effect of Parental Supportive Behaviors on life Satisfaction of adolescent off Spring . Journal of Marriage and the Family, 57 , pp. 813-822 . 
إدارة الشباب لوقت الفراغو علاقته بالرضا عن الحياة

\title{
Management of young people to leisure time and
}

its relationship with the satisfaction of life

By

\author{
Dr. Naglaa Sayed Hussein \\ Assistant Professor of Management \\ of Family Institutions and Childhood Department . \\ Faculty of Home Economics - Helwan University
}

The current research aims to reveal the relationship between the management of young people for leisure time and life satisfaction, and the sample consisted of 373 young men and girls who have completed their education and enrolled in the field of work in the public sector or the private sector, and aged (23-25 OVER) years, and has been selected from the province of Greater Cairo, and of the social and economic levels are different, and they applied the general form of data, scale management for young axes of leisure time, and the measure of life satisfaction dimensions have yielded results for :

1-the different relative weights of the dimensions of life satisfaction among young members of the research sample core occupied the accepted self ranking first, then psychological stability, which occupied the second place, followed by conviction and occupied the third place, followed by tranquility, which occupied the fourth position, then happiness and which occupied the fifth place, then achievement and who finished sixth order, and then estimate the social order and who finished seventh, and come in social ranked last .

2- The presence of statistically significant differences at the level of significance $(0.01),(0.05)$ between the mean management young people to spare time ( planning, implementation, evaluation ) depending on the variable sex ( males and females), educational level, profession, the average monthly income, and the differences in favor of males for the chart axis and was in favor of females for a pivotal implementation and evaluation, in favor of the high level of education for the variable level of 
education, and for the benefit of senior professional levels, and in favor of high-income levels .

3- The presence of statistically significant differences in life satisfaction among the young members of the research sample and at the level of significance ( 0.01), (0.05) for the study variables ( level of education, occupation, average monthly income ), and the differences were in favor of the high level of education for the variable level of education, and in favor of young people who have professions working for the Supreme variable profession, for the benefit of young people with high incomes for the variable average monthly income, while the differences were not a function for variable sex ( males and females) .

4- There is a positive correlation function at the level of significance between \$ (0.01) (0.05) between the Department of Youth leisure time Bmahorh (planning, implementation, evaluation ) and life satisfaction dimensions ( happiness , psychological stability, social recognition , conviction, social, tranquility, accept the self- achievement) .

5- There is a positive correlation between the Department of Youth leisure time Bmahorh (planning, implementation, evaluation ) and life satisfaction dimensions ( happiness, psychological stability, social recognition, conviction, social tranquility, accept the self, achievement ) , and between the study variables ( Level education, profession, age, the average monthly income), and that at the level of significance $(0.01),(0.05)$.

6- The proportion of post independent variables studied ( level of education , age, profession, the average monthly income ) on the dependent variable ( the Department of leisure time ), where he was the educational level of the young man or the girl was over and the most important variables that affected the management of young people for leisure time, followed by a variable Age, followed by a variable profession, and finally the average monthly income .

7- The proportion of post independent variables studied ( profession, level of education, the average monthly income, age) on the dependent variable ( life satisfaction ) where the profession young man or woman 
was over and the most important variables that affected the youth feeling good about life, followed by a variable level of education, followed by a variable average monthly income, and finally variable age .

And researcher recommends the need to train children from an early age on the good management of resources in general and supplier of spare time, including, in particular, goes back to them and society benefits . 